Prepared in cooperation with the Rhode Island Water Resources Board

\title{
Equations for Estimating Selected Streamflow Statistics in Rhode Island
}

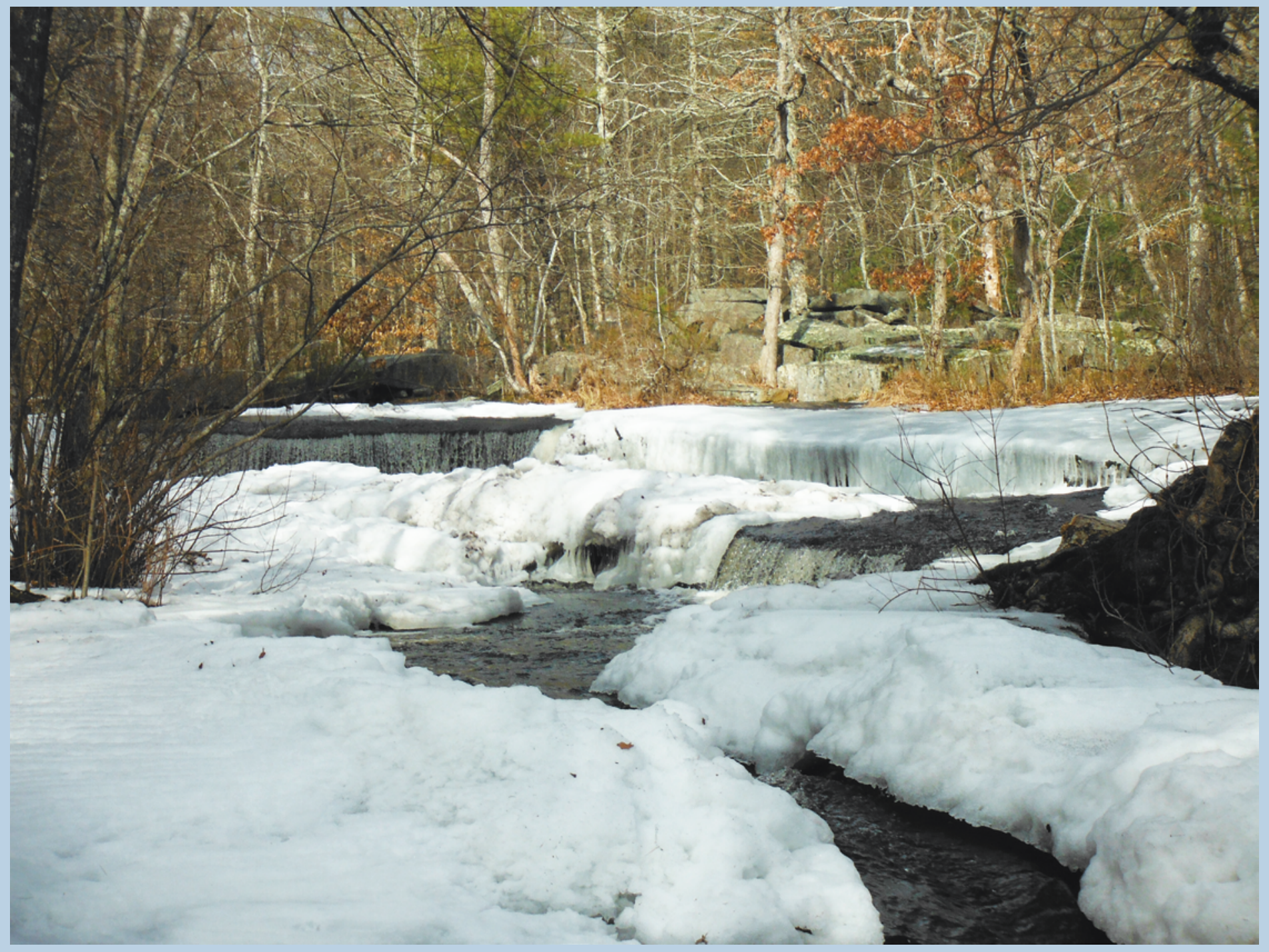

Scientific Investigations Report 2014-5010 
Front cover. Photograph of Wood River at Escoheag, Rhode Island (USGS partial-record station 01117720), also known as Stepstone Falls in the Arcadia Management Area in Rhode Island. 


\section{Equations for Estimating Selected Streamflow Statistics in Rhode Island}

By Gardner C. Bent, Peter A. Steeves, and Andrew M. Waite

Prepared in cooperation with the Rhode Island Water Resources Board

Scientific Investigations Report 2014-5010 


\title{
U.S. Department of the Interior SALLY JEWELL, Secretary
}

\section{U.S. Geological Survey Suzette M. Kimball, Acting Director}

\author{
U.S. Geological Survey, Reston, Virginia: 2014
}

For more information on the USGS - the Federal source for science about the Earth, its natural and living resources, natural hazards, and the environment, visit http://www.usgs.gov or call 1-888-ASK-USGS.

For an overview of USGS information products, including maps, imagery, and publications, visit http://www.usgs.gov/pubprod

To order this and other USGS information products, visit http://store.usgs.gov

Any use of trade, firm, or product names is for descriptive purposes only and does not imply endorsement by the U.S. Government.

Although this information product, for the most part, is in the public domain, it also may contain copyrighted materials as noted in the text. Permission to reproduce copyrighted items must be secured from the copyright owner.

Suggested citation:

Bent, G.C., Steeves, P.A., and Waite, A.M., 2014, Equations for estimating selected streamflow statistics in Rhode Island: U.S. Geological Survey Scientific Investigations Report 2014-5010, 65 p., http://dx.doi.org/10.3133/ sir20145010. 


\section{Acknowledgments}

The authors thank private landowners, towns, and the State of Rhode Island for allowing access to their land to collect streamflow data needed to develop equations for estimating selected streamflow statistics. The authors also thank the Rhode Island Water Resources Board and Rhode Island Department of Environmental Management for providing input on the selected streamflow statistics.

Thanks are extended to Stacey Archfield, Ken Eng, Gregory Granato, Julie Kiang, and David Lorenz of the U.S. Geological Survey (USGS) for their input on development of the equations and to Domenic Murino, Mark Nimiroski, Lance Ramsbey, and the many other USGS employees who measured the streamflows in Rhode Island, Connecticut, and Massachusetts for this study. 



\section{Contents}

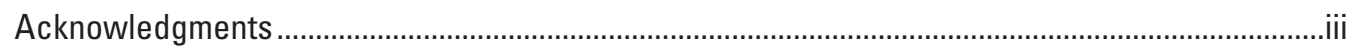

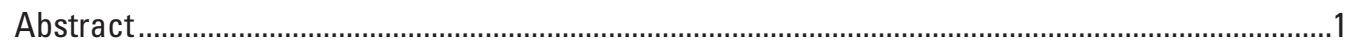

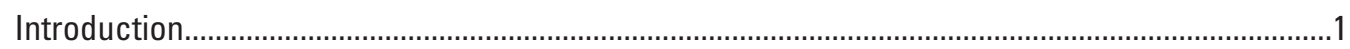

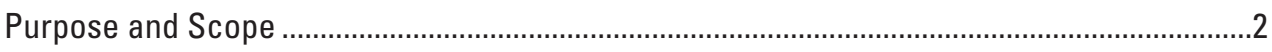

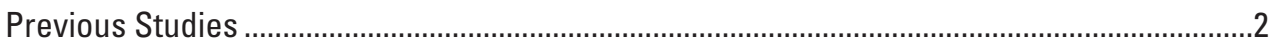

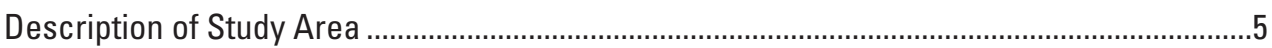

Development of the Streamflow Statistics and Basin Characteristics Datasets .............................6

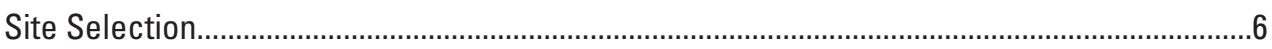

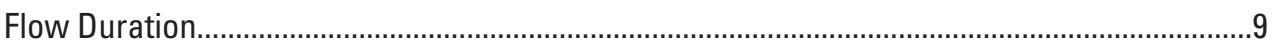

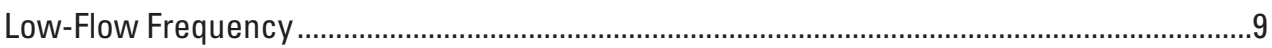

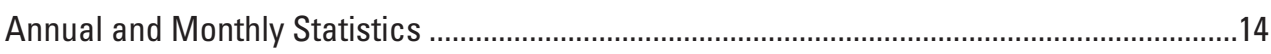

Flow Statistics for Long-Term Streamgages .........................................................................16

Flow Statistics for Short-Term Streamgages and Partial-Record Stations ............................17

Basin Characteristics for Streamgages and Partial-Record Stations ....................................19

Equations for Estimating Selected Streamflow Statistics ...........................................................21

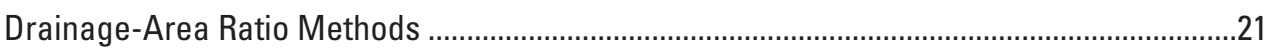

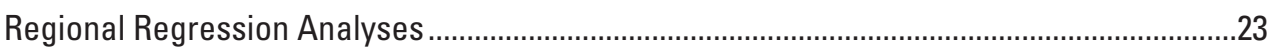

Development of Regression Equations .......................................................................

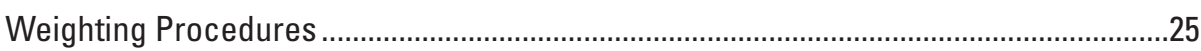

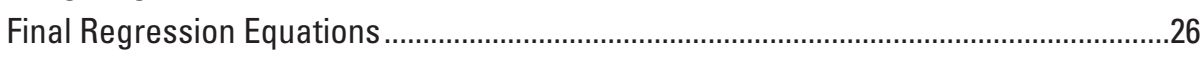

Prediction Intervals ...................................................................................................

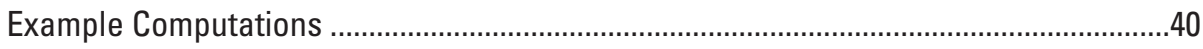

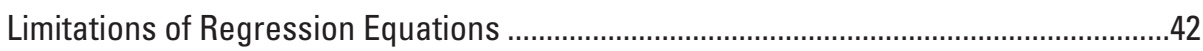

StreamStats Application and Considerations for Additional Study ...............................46

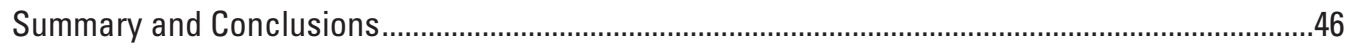

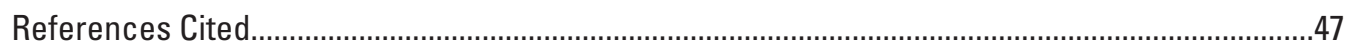

\section{Figures}

1. Map showing locations of the drainage basins in the study area in and near Rhode Island ...............................................................................................................

2. Map showing locations of the index, long-term, and short-term streamgages in and near Rhode Island.

3. Graph showing annual mean streamflows at the streamgages Branch River at Forestdale, R.I. (01111500), and Pawcatuck River at Wood River Junction, R.I. (01117500), for water years 1942-2009 .....................................................................

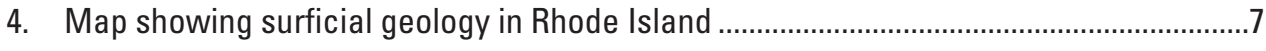

5. Map showing general land use in Rhode Island ...............................................................

6. Flow-duration curves at the streamgages Adamsville Brook at Adamsville, R.I. (01106000), and Beaver River near Usquepaug, R.I. (01117468).

7. Graph showing example of the fit of the log-Pearson Type III distribution to the annual 7-day low flow at the streamgage Branch River at Forestdale, R.I. (01111500), for water years $1941-2006$. 
8. Map showing locations of the partial-record stations in and near Rhode Island ...........18

9. Graph showing example of Maintenance of Variance Extension, type 1 (MOVE.1), relation between concurrent daily mean streamflows at the short-term streamgage Chickasheen Brook at West Kingston, R.I. (01117424), and the index streamgage Beaver River near Usquepaug, R.I. (01117468).

10. Graph showing example of Maintenance of Variance Extension, type 1 (MOVE.1), relation between concurrent miscellaneous streamflow measurements at the partial-record station Burnt Swamp Brook near Grant Mills, R.I. (01113670), and daily mean streamflows at the index streamgage Wading River near Norton, Mass. (01109000)

11. Maps showing the residuals between measured streamflows and streamflows calculated by regression equations for the $A, 7010$ low-flow frequency, and $B, 95-$, $C, 75-, D, 50-, E, 25-$, and $F, 5$-percent flow durations for long-term and short-term streamgages in and near Rhode Island

12. Graphs showing comparisons of the $A, 7010$ low-flow frequency, and $B, 95-, C, 75-$, $D, 50-, E, 25-$, and $F, 5$-percent flow durations estimated from measured streamflow and regression equations for long-term and short-term streamgages in and near Rhode Island.

\section{Tables}

1. Description of long- and short-term streamgages in and near Rhode Island.

2. List of selected streamflow statistics computed for long- and short-term streamgages and partial-record stations in and near Rhode Island

3. Estimated streamflow statistics for long- and short-term streamgages in and near Rhode Island.

4. Description of partial-record stations in and near Rhode Island

5. Summary of data used by the Maintenance of Variance Extension, type 1 (MOVE.1), record-extension technique to estimate long-term streamflow statistics for shortterm streamgages and partial-record stations in and near Rhode Island.

6. Estimated streamflow statistics for partial-record stations in and near Rhode Island

7. List of basin characteristics determined for long- and short-term streamgages and partial-record stations in and near Rhode Island

8. Basin characteristics for long- and short-term streamgages in and near Rhode Island

9. Basin characteristics for partial-record stations in and near Rhode Island

10. Pearson's correlation coefficients for basin characteristics evaluated as potential explanatory variables for regression equations for estimating selected streamflow statistics for long- and short-term streamgages in Rhode Island.

11. Summary of regression equations and measures of model accuracy for estimating selected streamflow statistics in Rhode Island.

12. Information needed for calculating the 90-percent prediction intervals for estimates of selected statistics calculated by regression equations for streamflows in Rhode Island.

13. Range of basin characteristics used as explanatory variables in the regression equations for estimating selected streamflow statistics in Rhode Island 


\section{Conversion Factors, Datum, and Abbreviations}

\begin{tabular}{lcl}
\hline \multicolumn{1}{c}{ Multiply } & By & \multicolumn{1}{c}{ To obtain } \\
\hline inch (in.) & Length & \\
foot (ft) & 25.4 & millimeter $(\mathrm{mm})$ \\
mile (mi) & 0.3048 & meter $(\mathrm{m})$ \\
\hline \multicolumn{3}{c}{ kilometer $(\mathrm{km})$} \\
\hline square mile $\left(\mathrm{mi}^{2}\right)$ & 1.609 & krea \\
\hline & 2.590 & square kilometer $\left(\mathrm{km}^{2}\right)$ \\
\hline $\begin{array}{l}\text { cubic foot per second }\left(\mathrm{ft}^{3} / \mathrm{s}\right) \\
\text { cubic foot per second per square mile } \\
{\left[\left(\mathrm{ft}^{3} / \mathrm{s}\right) / \mathrm{mi}^{2}\right]}\end{array}$ & Flow rate & \\
\hline
\end{tabular}

Temperature in degrees Celsius $\left({ }^{\circ} \mathrm{C}\right)$ may be converted to degrees Fahrenheit $\left({ }^{\circ} \mathrm{F}\right)$ as follows:

${ }^{\circ} \mathrm{F}=\left(1.8 x^{\circ} \mathrm{C}\right)+32$

Temperature in degrees Fahrenheit $\left({ }^{\circ} \mathrm{F}\right)$ may be converted to degrees Celsius $\left({ }^{\circ} \mathrm{C}\right)$ as follows:

${ }^{\circ} \mathrm{C}=\left({ }^{\circ} \mathrm{F}-32\right) / 1.8$

Vertical coordinate information is referenced to the North American Vertical Datum of 1988 (NAVD 88).

Horizontal coordinate information is referenced to the North American Datum of 1983 (NAD 83).

Altitude, as used in this report, refers to distance above the vertical datum.

\section{Abbreviations}

\section{Agencies}

$\begin{array}{ll}\text { CLEAR } & \text { University of Connecticut-Center for Land Use Education and Research } \\ \text { MAGIC } & \text { University of Connecticut-Map and Geographic Information Center } \\ \text { MassGIS } & \text { Massachusetts Office of Geographic Information } \\ \text { NRCS } & \text { Natural Resources Conservation Service } \\ \text { RIDEM } & \text { Rhode Island Department of Environmental Management } \\ \text { RIGIS } & \text { Rhode Island Geographic Information System } \\ \text { RIWRB } & \text { Rhode Island Water Resources Board } \\ \text { USGS } & \text { U.S. Geological Survey }\end{array}$




\title{
Basin Characteristics
}

\author{
DRNAREA Drainage area, in square miles \\ STRDENED Stream density, in miles per square mile
}

\section{Miscellaneous}

$\begin{array}{ll}\text { 7Q2 } & \text { 7-day, 2-year low-flow frequency } \\ \text { 7Q10 } & \text { 7-day, 10-year low-flow frequency } \\ \text { BCF } & \text { bias correction factor } \\ \text { GIS } & \text { geographic information system } \\ \text { GNWISQ } & \text { Get National Water Information System Streamflow } \\ \text { LTG } & \text { long-term streamgage } \\ \text { MOVE.1 } & \text { Maintenance of Variance Extension, type 1 } \\ \text { MSE } & \text { mean square error } \\ \text { NWIS } & \text { National Water Information System-USGS } \\ \text { NED } & \text { National Elevation Dataset-USGS } \\ \text { NHD } & \text { National Hydrography Dataset-USGS } \\ \text { PRISM } & \text { Parameter-Elevation Regressions on Independent Slopes Model-Climate Group, } \\ r & \text { Oregon State University } \\ R^{2} & \text { Pearson's correlation coefficient } \\ \text { RI-ABF } & \text { coefficient of determination } \\ \text { RMSE } & \text { Rhode Island Aquatic Base-Flow Methodology } \\ \text { SSURGO } & \text { root mean square error } \\ \text { STG } & \text { Soil Survey Geographic Database-Natural Resources Conservation Service } \\ \text { WLS } & \text { short-term streamgage } \\ \text { WREG } & \text { weighted least-squares regression analysis } \\ & \text { weighted-multiple-linear regression program }\end{array}$




\title{
Equations for Estimating Selected Streamflow Statistics in Rhode Island
}

\author{
By Gardner C. Bent, Peter A. Steeves, and Andrew M. Waite
}

\section{Abstract}

Regional regression equations were developed for estimating selected natural - unaffected by alterationstreamflows of specific flow durations and low-flow frequency statistics for ungaged stream sites in Rhode Island. Selected at-site streamflow statistics are provided for 41 long-term streamgages, 21 short-term streamgages, and 135 partialrecord stations in Rhode Island, eastern Connecticut, and southeastern and south-central Massachusetts. The regression equations for estimating selected streamflow statistics and the at-site statistics estimated for each of the 197 sites may be used by Federal, State, and local water managers in addressing water issues in and near Rhode Island.

Multiple and simple linear regression equations were developed to estimate the 99-, 98-, 95-, 90-, 85-, 80-, 75-, 70-, 60-, 50-, 40-, 30-, 25-, 20-, 15-, 10-, 5-, 2-, and 1-percent flow durations and the 7Q2 (7-day, 2-year) and 7Q10 (7-day, 10-year) low-flow-frequency statistics. An additional 49 selected statistics, for which regression equations were not developed, also were estimated for the long- and short-term streamgages and partial-record stations for flow durations between the 99.99 and 0.01 percent and for the mean annual, mean monthly, and median monthly streamflows. A total of 70 selected streamflow statistics were estimated for 41 long-term streamgages, 21 short-term streamgages, and 135 partial-record stations in and near Rhode Island. Estimates of the long-term streamflow statistics for the 21 short-term streamgages and 135 partial-record stations were developed by the Maintenance of Variance Extension, type 1 (MOVE.1), record-extension technique.

The equations used to estimate selected streamflow statistics were developed by relating the 19 flow-duration and 2 low-flow-frequency statistics to 31 different basin characteristics (physical, land-cover, and climatic) at the 41 long-term and 19 of 21 short-term streamgages (a total of 60 streamgages) in and near Rhode Island. The 135 partialrecord stations were not used in the regression analyses. The regression analyses were done by using a user-weighted leastsquares technique in the weighted-multiple-linear regression program for the 90- to 1-percent flow-duration statistics. For the 99-, 98-, and 95-percent flow durations and the 7Q2 and $7 \mathrm{Q} 10$ statistics, left-censored regression analyses were used to account for zero flows at a few streamgages. The regression analyses determined that two basin characteristicsdrainage area and stream density - were the only significant explanatory variables for 16 of the 19 flow-duration and the 2 low-flow regression equations. For the 10-, 15-, and 20-percent flow-duration regression equations, drainage area was the only significant explanatory variable. The standard error of the estimate for the 21 regression equations ranged from 17.58 to 141.83 percent. The 99 - to 85 -percent flow durations and the low-flow statistics 7Q2 and 7Q10 had the highest standard errors of the estimate, ranging from 48.68 to 141.83 percent. The standard error of the estimate for the medium- to high-flow statistics - the 80- to 1-percent flow durations-ranged from 17.58 to 37.65 percent, with the standard errors for the 60- to 1-percent flow durations all being less than about 21 percent. Data also are provided to allow the user to calculate the 90-percent prediction intervals for the 21 streamflow statistics.

The equations, which are based on data from streams with little to no flow alterations, will provide an estimate of the natural flows for a selected site. They will not estimate flows for altered sites with dams, surface-water withdrawals, groundwater withdrawals (pumping wells), diversions, and wastewater discharges. If the equations are used to estimate streamflow statistics for altered sites, the user should adjust the flow estimates for the alterations. The regression equations should be used only for ungaged sites with drainage areas between 0.52 and 294 square miles and stream densities between 0.94 and 3.49 miles per square mile; these are the ranges of the explanatory variables in the equations.

\section{Introduction}

Flow statistics for streams are crucial for waterresources planning, management, and permitting to ensure adequate water for consumptive use, water-quality standards, recreation, and aquatic habitat. For example, the minimum 7-day-average flow that has a probability of occurring once every 10 years $(7 \mathrm{Q} 10)$ is a streamflow statistic frequently referenced by regulatory agencies as a threshold criterion for waste-load assimilation of point discharges and other water-resource-protection issues. Information on streamflow 
statistics is critical for water-resource managers who make decisions, especially during drought periods. For example, in Rhode Island (fig. 1), drought periods occurred during 1930-31, 1941-45, 1949-50, 1963-67, 1980-81, and 1987-88 (Walker and Lautzenheiser, 1991). Most of these drought periods correspond to intervals when the annual mean streamflow was well below the long-term mean annual streamflow records for Branch River at Forestdale, R.I. (01111500), and Pawcatuck River at Wood River Junction, R.I. (01117500) (figs. 2 and 3), in northern and southern Rhode Island, respectively. Other shorter periods of low flow similar to those during the drought period noted previously can be seen in 1957, 1985, 1995, 2002, and 2008 (fig. 3).

In Rhode Island, instream flow standards have become more of a critical topic since the early 2000s with reports on how to develop these standards by the Rhode Island Water Resources Board (RIWRB) Water Allocation Program Advisory Committee (2004). The State developed a modified Aquatic Baseflow (RI-ABF) Methodology (Rhode Island Department of Environmental Management, Office of Water Resources, 2005) to assist in developing these instream streamflow standards. The RI-ABF methodology includes a site-specific standard that allows for maximum sustainable use of the State's waters but that is also protective of the biological, chemical, and physical integrity of those waters. A draft describing a streamflow-depletion methodology (Rhode Island Department of Environmental Management, Office of Water Resources, 2010) was developed to determine the maximum volume of water that can be extracted from a stream (whether as direct stream withdrawals or indirect groundwater withdrawals) yet leave sufficient streamflow to maintain habitat conditions essential to a healthy aquatic ecosystem.

Additionally, the Rhode Island Department of Environmental Management (RIDEM) and Rhode Island Water Resources Board Streamflow Committee (2004) made recommendations for a streamgage network to allow proper management of the State's water resources. The streamgage network is intended to provide streamflow data for the development of regression equations for estimated streamflow statistics at ungaged sites in Rhode Island.

This study was done from 2007-11 by the U.S. Geological Survey (USGS) in cooperation with the RIWRB. This study provides the RIWRB; RIDEM; Providence Water Supply Board; other federal, state, county, city, and town agencies; nongovernmental and private organizations; and the public with regression equations for estimating selected streamflow statistics for ungaged stream sites and at-site streamflow statistics for long- and short-term streamgages and partial-record stations in and near Rhode Island. Streamflow statistics can inform planning, management, and permitting decisions related to ensuring adequate water for consumptive use, water-quality standards, recreation, and aquatic habitat in Rhode Island. In addition, the streamflow statistics can be used by the RIWRB in identifying water sources where uses might exceed the safe yield under the Rhode Island General Laws 46-15.7-3.

\section{Purpose and Scope}

This report describes regression equations developed for estimating selected statistics for streamflows in Rhode Island from basin, land-use, and climatological characteristics. The selected streamflow statistics estimated with the regression equations are for natural flow conditions (unaltered streamflows). The report provides estimates of selected streamflow statistics for long- and short-term streamgages and partialrecord stations in and near Rhode Island. Streamflow statistics for which regression equations were developed include the 99-, 98-, 95-, 90-, 85-, 80-, 75-, 70-, 60-, 50-, 40-, 30-, 25-, 20-, 15-, 10-, 5-, 2-, and 1-percent flow durations and the 7Q2 (7-day, 2-year) and 7Q10 (7-day, 10-year) low-flow frequencies. An evaluation of the accuracies of the equations and the limitations for their use are provided with example applications. Additionally, estimated statistics are provided for longand short-term streamgages and partial-record stations for other selected flow durations between the 99.99- and 0.01percentiles and for the mean annual, mean monthly, and median monthly streamflows; however, regression equations were not developed for these statistics.

\section{Previous Studies}

Kliever (1996) estimated the 99-, 98-, 97-, 95-, 90-, 85-, 80-, 70-, 60-, 50-percent flow durations, 7Q10, and mean monthly streamflows for August, February, April, and May for 16 partial-record stations in northern Rhode Island. Cervione and others (1993) calculated the 80-, 90-, 95-, 98-, and 99-percent flow durations for 25 partial-record stations in southern Rhode Island. Cervione and others (1993) also presented a regression equation to estimate the 7Q10 for selected streams in Rhode Island. The equation does not provide an estimate of the potential error of the 7 Q10 and is based on only 4 continuous-record streamgages in southwestern Rhode Island, 5 streamgages in eastern Connecticut, 8 streamgages in western Connecticut, 2 streamgages in western Massachusetts, and 2 streamgages in eastern New York with data through water year 1991. Currently (2014) selected streamflow statistics may be estimated for about 25 continuous-record streamgages, 10 discontinued streamgages, and about 90 partial-record stations throughout Rhode Island. Wandle and Randall (1994) developed regression equations for estimating the 7Q2 and 7Q10 for central New England, which includes Rhode Island. Seven of the 51 streamgages used in the regression analyses were in Rhode Island. Ries (1990) estimated mean annual runoff from major drainage areas in Rhode Island and Massachusetts to Narragansett Bay. Additionally, Haecker (2000) provided estimates of base flow at selected streams in Rhode Island.

In the adjacent States of Connecticut and Massachusetts, several additional studies have published regression equations for estimating selected low-flow statistics over the last 


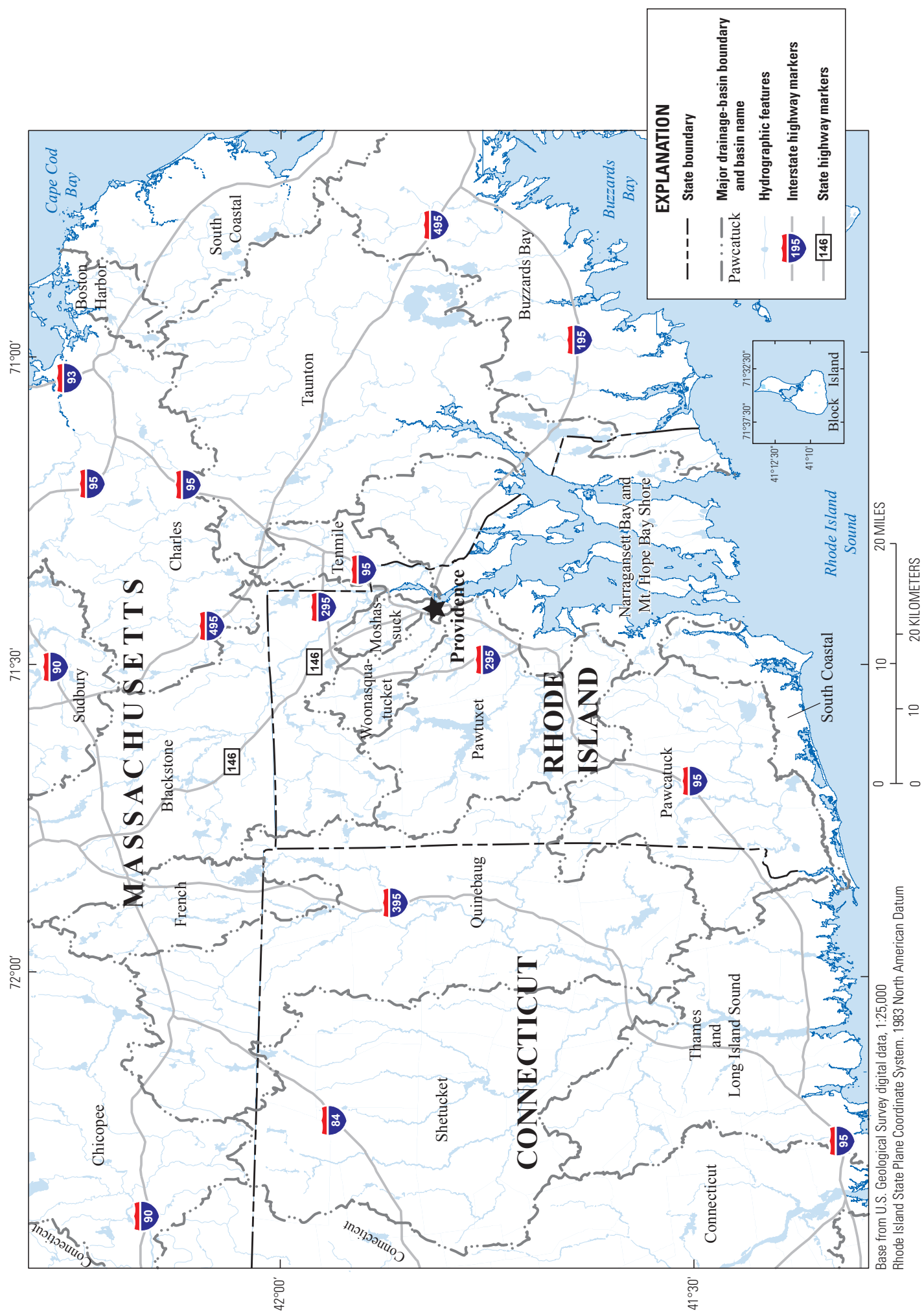

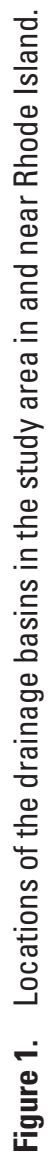




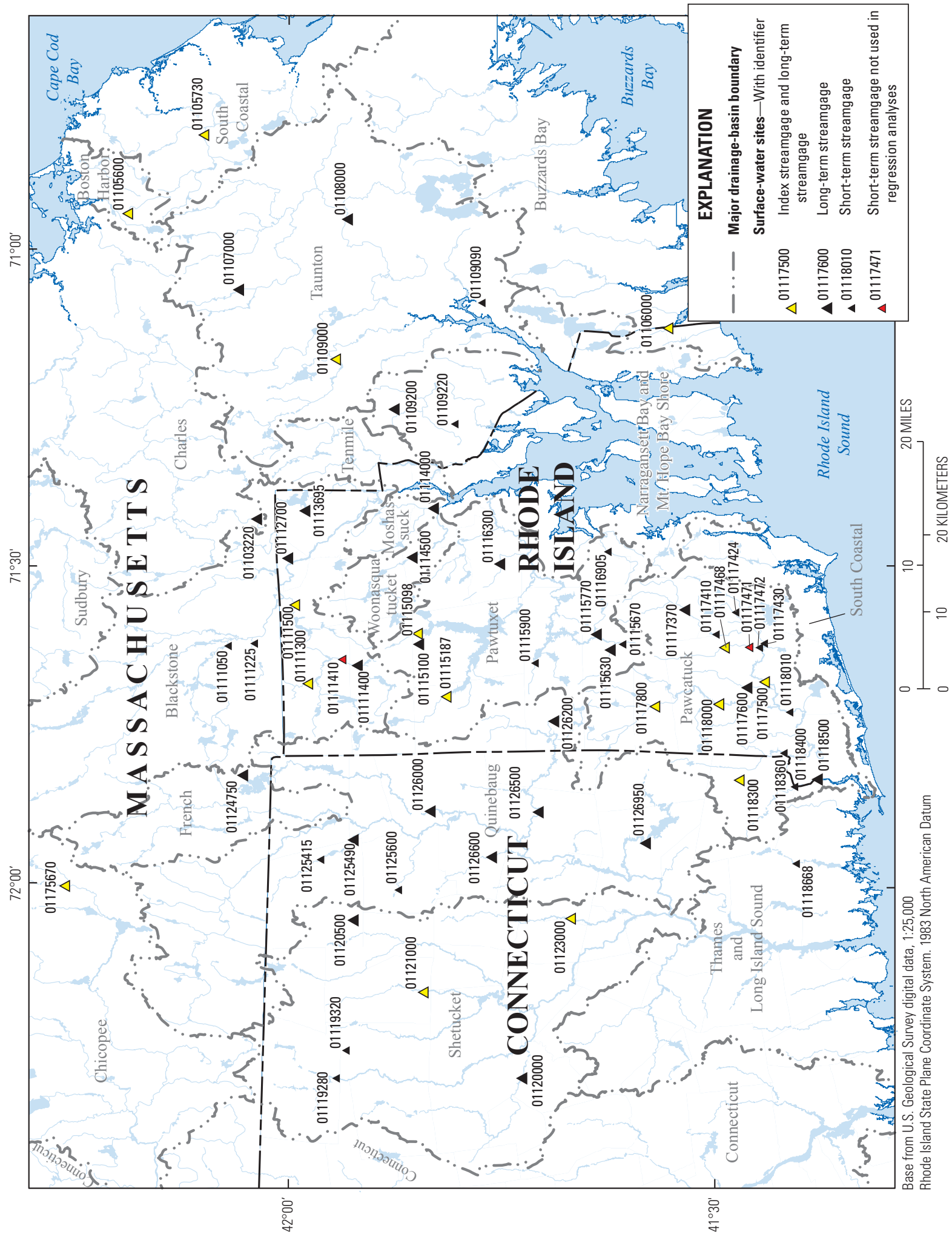

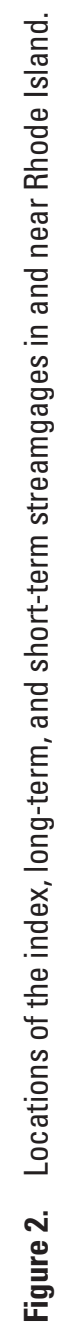




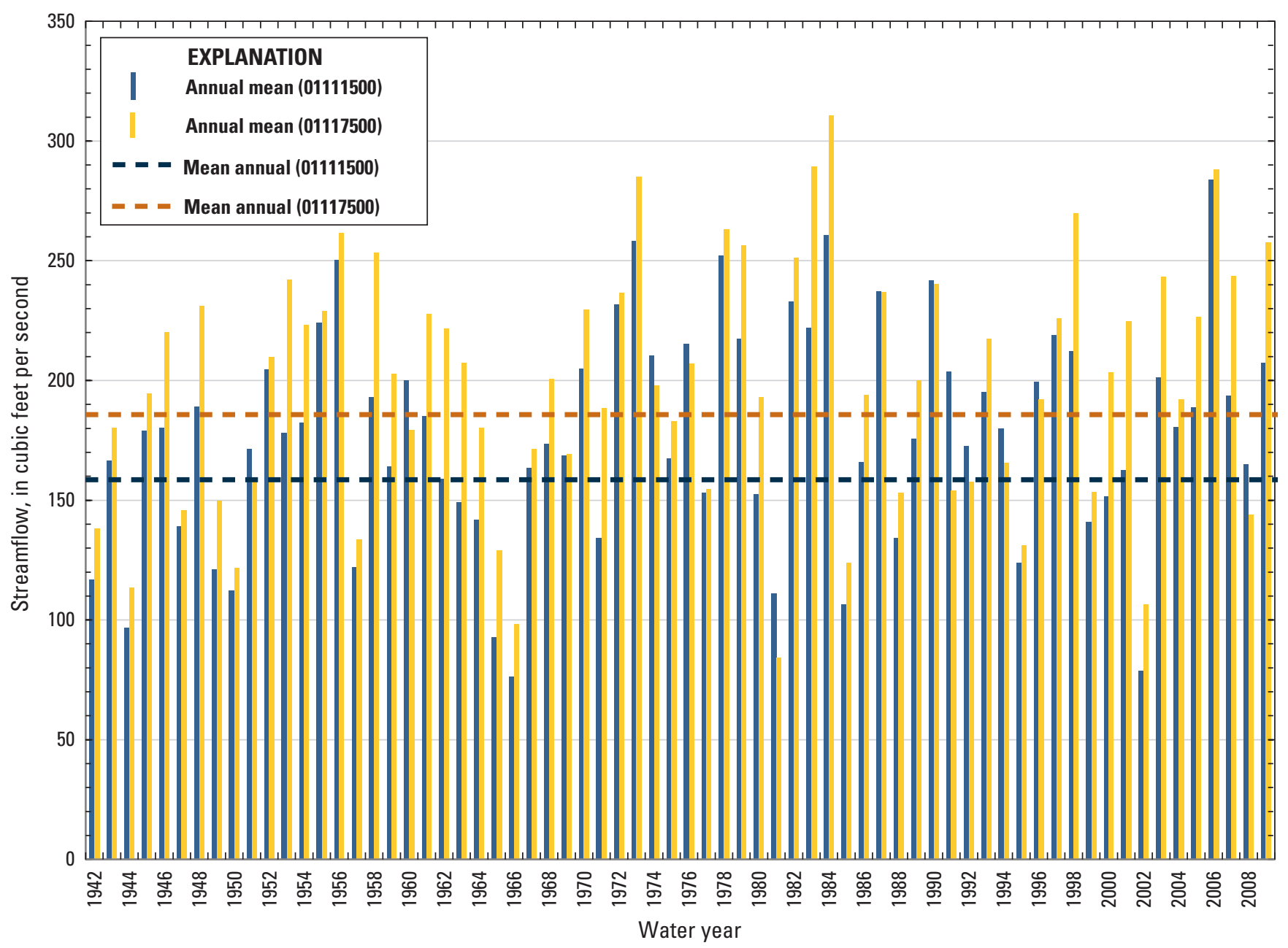

Figure 3. Annual mean streamflows at the streamgages Branch River at Forestdale, R.I. (01111500), and Pawcatuck River at Wood River Junction, R.I. (01117500), for water years 1942-2009.

20 years. Ahearn (2008 and 2010) and Ahearn and others (2006) provided estimated streamflow statistics and regression equations for various flow durations, 7Q2, 7Q10, and seasonal flows based on aquatic habitat needs in Connecticut. Fennessey and Vogel (1990), Vogel and Kroll (1990), Ries (1990), Risley (1994), Ries (1994a, 1994b, 1997, and 1999), Ries and Friesz (2000), Ries and others (2000), and Archfield and others (2010) provided estimated streamflow statistics and regression equations for various flow durations, 7Q2, and 7Q10 in Massachusetts. Armstrong and others (2008) provided regression equations for estimating median monthly streamflows in Massachusetts. Bent and Archfield (2002) and Bent and Steeves (2006) provided logistic regression equations for estimating the probability of a stream flowing perennially in Massachusetts.

\section{Description of Study Area}

Rhode Island encompasses 1,045 square miles $\left(\mathrm{mi}^{2}\right)$ in the northeastern United States (fig. 1). Altitudes range from sea level (defined as the North American Vertical Datum of 1988) in coastal areas to 812 feet (ft) above sea level in the northwest. Altitudes generally increase from southeast to northwest in Rhode Island. The climate is humid and temperate. Average annual precipitation ranged from 40 to 53 inches (in.) during 1971-2000 and is fairly evenly distributed throughout the months (National Oceanic and Atmospheric Administration, 2002). Average annual temperature ranged from 48 to $52^{\circ} \mathrm{F}$; the minimum ranged from 26 to $33^{\circ} \mathrm{F}$ in January, and the maximum ranged from 71 to $73^{\circ} \mathrm{F}$ in July (National Oceanic and Atmospheric Administration, 2002). 
About half of the annual precipitation is returned to the atmosphere through evaporation and plant transpiration, with the remainder becoming groundwater recharge or stream runoff.

Surficial deposits that overlie bedrock in most of Rhode Island were deposited mainly during the last glacial period but can include areas of recent flood-plain alluvium deposits. In this report, these surficial deposits are classified as either till (which includes till or bedrock, sandy till over sand, and end-moraine deposits) or outwash (stratified) deposits (which includes sand and gravel, coarse sand, finegrained sand, and flood-plain alluvium deposits) (fig. 4). Till (also known as ground moraine) is an unsorted, unstratified mixture of clay, silt, sand, gravel, cobbles, and boulders that were deposited by glaciers, commonly on top of bedrock throughout much of the State. Surficial till is primarily found in upland areas but can also be found at depth in river valleys. Outwash deposits include sorted and layered glaciofluvial and glaciolacustrine deposits. Glaciofluvial deposits are material of all grain sizes (clay, silt, sand, gravel, and cobbles) deposited by glacial meltwater streams in outwash plains and river valleys. Glaciolacustrine deposits generally consist of clay, silt, and fine sand deposited in temporary lakes that formed after the retreat of the glacial ice sheet. Outwash deposits are more widespread in central and southern Rhode Island than in eastern, northern, and western Rhode Island (fig. 4) (Trench, 1991; DeSimone and Ostiguy, 1999, p. 4). The outwash deposits are mainly along the major river valleys, and the till deposits and exposed bedrock are in the upland areas. In the southern coastal area of the State is a large mixed deposit (fig. 4), often referred to as the Charlestown moraine, that acts as a physical barrier to surface-water flow heading south and sends it toward the southwest to a point of discharge into the Atlantic Ocean (Masterson and others, 2007; Friesz, 2010; and Bent and others, 2011).

Land in Rhode Island is primarily forested outside of the Providence metropolitan area (fig. 5). The Providence metropolitan area is generally bound by Interstates I-95, I-295, and I-195 and the State border with Massachusetts (fig. 1) and consists primarily of moderate- to high-density housing and commercial and industrial facilities (fig. 5). From 1970 to 1995 there was a 47-percent increase in the developed land area in Rhode Island, with the greatest increases in the areas of residential, commercial, and industrial land (Rhode Island Statewide Planning Program, 2000).

Rhode Island is within the central highlands, coastal lowlands, and coastal plain physiographic provinces (Denny, 1982). The central highlands physiographic province is limited to west central and northwestern areas of the State. The remainder of the State is within the coastal lowlands physiographic province, excluding Block Island, which is within the coastal plain province. Rhode Island is entirely within the Northeastern Coastal Zone of the U.S. Environmental Protection Agency (EPA) (2006) level III ecoregions, excluding Block Island, which is within the Atlantic Coastal Pine Barrens ecoregion. The level III ecoregions are delineated on the basis of geology, physiography, vegetation, climate, soils, land use, wildlife, and hydrology.

Block Island (fig. 1-inset map), which is about 10 miles (mi) south of the mainland coast of Rhode Island, was not included in the study area because the topographic map of Block Island for the 12- $\mathrm{mi}^{2}$ island shows no streams. Veeger and Johnston (1996) reported that streams are absent throughout most of the island, except for a few springs along the base of the sea cliffs on the southern part of the island.

\section{Development of the Streamflow Statistics and Basin Characteristics Datasets}

Historical streamflow data for USGS streamgages are available in the USGS National Water Information System (NWIS) database at the Web site http://waterdata.usgs.gov/ nwis. These streamflow data can be analyzed to determine particular statistics - such as flow durations, flow frequencies, and monthly and annual statistics - which are used by water managers throughout the country. Basin characteristics for physical, land-use, and climatological data are developed with geographic information system (GIS) data layers from Federal, State, and local government agencies and nongovernmental agencies.

\section{Site Selection}

All active and discontinued long- and short-term streamgages and partial-record stations in Rhode Island, eastern Connecticut, and southeastern and south-central Massachusetts were evaluated for possible use in the regional regression analyses. Long-term streamgages were defined as those having 8 or more years of record (both water years ${ }^{1}$ and climatic years ${ }^{2}$ ) through water year 2006. Short-term streamgages were defined as those having fewer than 8 years of record through water year 2009. Partial-record stations were considered if they had at least 10 streamflow measurements through water year 2006. Sites in eastern Connecticut and southeastern and south-central Massachusetts were limited to those within about $25 \mathrm{mi}$ of the Rhode Island border. All of the sites in the three States considered are within the Northeast Coastal Zone of the U.S. Environmental Protection Agency Ecoregion level III (2006) and are based on geology, physiography, vegetation, climate, soils, land use, wildlife, and hydrology.

All potential sites were evaluated for flow alteration processes such as water withdrawals, diversions, flood

\footnotetext{
${ }^{1} \mathrm{~A}$ water year is the 12 -month period beginning October 1 and ending September 30. It is numbered by the calendar year in which it ends.

${ }^{2} \mathrm{~A}$ climatic year is the 12-month period beginning April 1 and ending March 31. It is numbered by the calendar year in which it ends.
} 


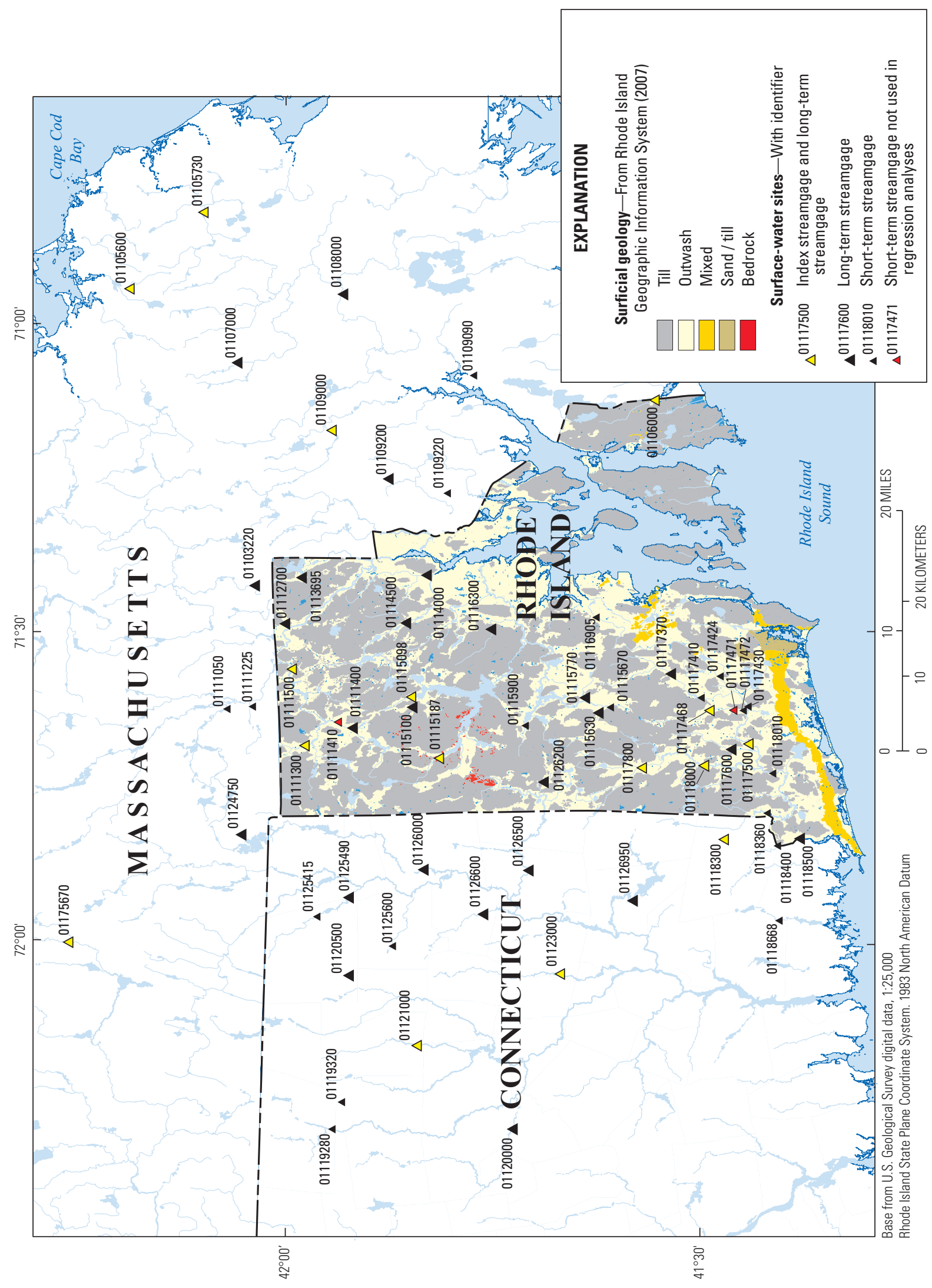

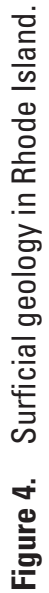




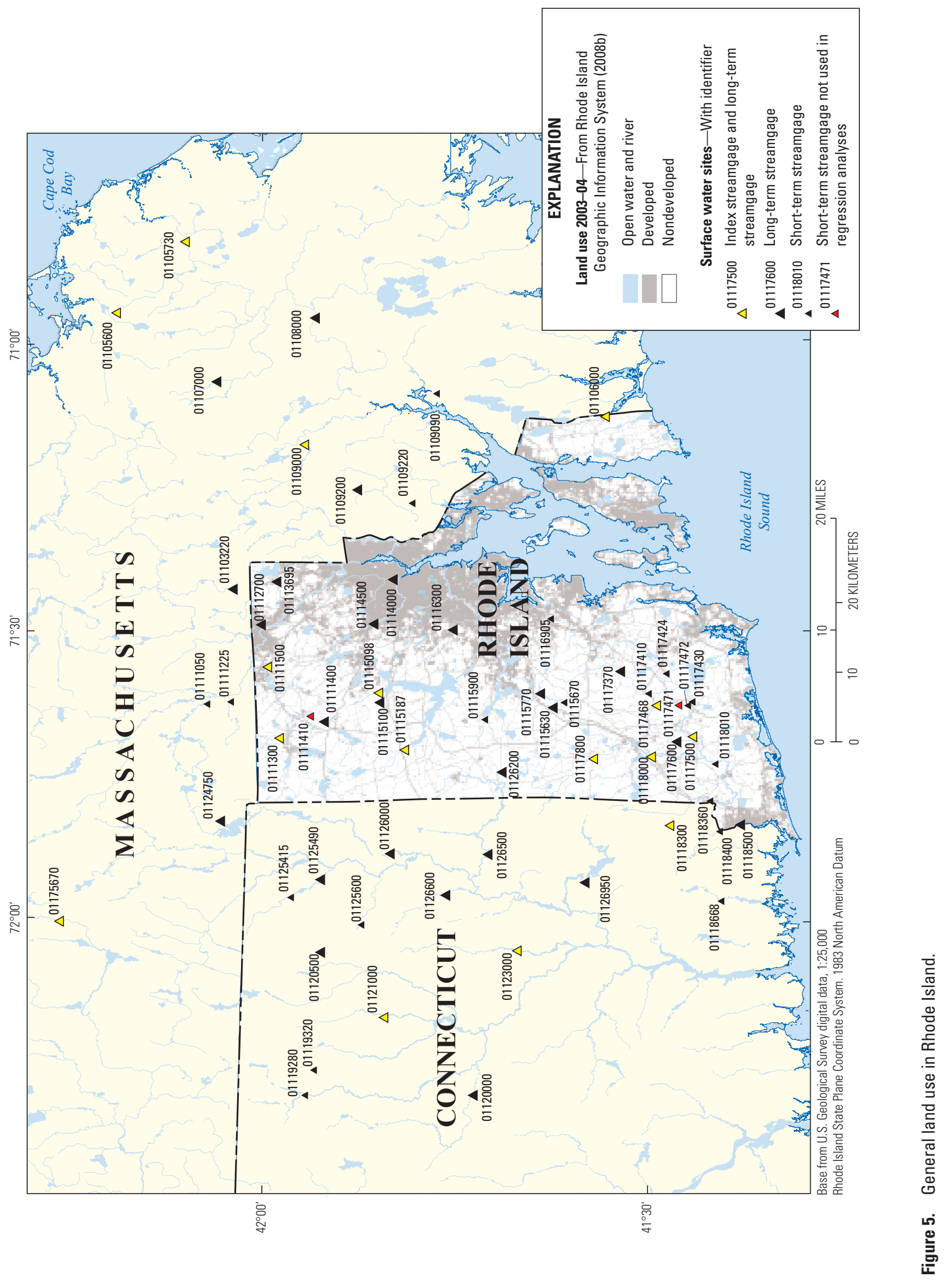


control, and wastewater discharge. Those sites with known flow-altered processes within their drainage basins that were significant enough to clearly change the recorded daily mean streamflows for more than several days during each water year were excluded from the dataset. The final list of sites included 41 long-term streamgages (22 in Rhode Island, 10 in Connecticut, and 9 in Massachusetts), 21 short-term streamgages (11 in Rhode Island, 6 in Connecticut, and 4 in Massachusetts), and 135 partial-record stations (95 in Rhode Island, 25 in Connecticut, and 15 in Massachusetts).

\section{Flow Duration}

Flow durations represent the percentage of time that a given flow is equaled or exceeded without regard to the sequence of recorded flows (Searcy, 1959). Typically, flow durations characterize the range of flow rates for the period over which data were collected. Flow durations were computed for complete water years for the entire period of record for 41 long-term streamgages (table 1 and fig. 2) with 8 or more complete water years of record. Flow durations are computed by sorting the daily mean streamflows for the period of record from largest to smallest and assigning each streamflow value a rank, starting with 1 for the largest value. The frequencies of exceedance are then computed by using the Weibull plotting-position formula (Weibull, 1939):

$$
P=100 *[M /(n+1)]
$$

where

$$
\begin{array}{cl}
P \quad \text { is the probability that a given streamflow will } \\
\text { be equaled or exceeded (percent of time), } \\
M \quad \text { is the ranked position (dimensionless), and } \\
n \quad \text { is the number of events (daily mean } \\
\text { streamflow values) for the period of record } \\
\text { (dimensionless). }
\end{array}
$$

Examples of flow-duration curves are provided for the Adamsville Brook at Adamsville, R.I. (01106000), and for the Beaver River near Usquepaug, R.I. (01117468), streamgages (fig. 6). The drainage areas to these streamgages are similar in size, about $9 \mathrm{mi}^{2}$, and their record lengths are fairly similar-38 and 36 years, respectively - but both show distinctly different flows over much of the flow-duration curve. These differences are the results of their different periods of record, physical basin characteristics, land-use characteristics, and (or) climatic factors.

The program Make Plotting Position (MkPP) (Granato, 2009) computed the selected flow durations by using the Weibull plotting-position formula. The selected flow durations range from 99.99 to 0.01 percent, with the number of selected durations increasing in the extreme percentile ranges (99.99 to 90 and 10 to 0.01 ) (table 2). These selected flow durations were considered to most accurately define the flow-duration curve for a streamgage or for estimating streamflows at an ungaged site. The streamflow data to be used in the MkPP program were downloaded for complete water years during the streamgages' periods of record through water year 2006 by using the computer program Get National Water Information System Streamflow (GNWISQ) (Granato, 2009). For the streamgages Miscoe Brook near Franklin, Mass. (01103220), Catamint Brook at Cumberland, R.I. (01113695), and Queen River at Liberty Road, at Liberty, R.I. (01117370), data through water year 2009 were used, so that these streamgages could be used in this study as long-term streamgages ( 8 or more complete water years of record) instead of being used as short-term streamgages with estimated statistics. Estimated streamflows for the selected flow durations at the long-term streamgages are presented in table 3 .

Table 3. Estimated streamflow statistics for long- and short-term streamgages in and near Rhode Island.

[Available separately at http://pubs.usgs.gov/sir/2014/5010/ tables/sir2014-5010_bent_table03.xlsx]

\section{Low-Flow Frequency}

Low-flow frequencies typically are computed for streamgages by use of annual series of selected low flows based on the lowest mean streamflow for a specified number of consecutive days (Riggs, 1972). Any combination of number of days of mean minimum flow and years of recurrence may be used to determine the low-flow frequencies. The annual series for the determination of low-flow frequencies for this study was based on a climatic year. Use of a climatic year rather than a water year allows for an analysis of an uninterrupted low-flow period; in Rhode Island, this low-flow period typically occurs from early August through mid-October.

Low-flow frequencies were computed for selected days and frequencies for 41 long-term streamgages (table 1 and fig. 2) with 8 or more complete climatic years. Low-flow frequencies are based on the D-day, Y-year frequency statistic of daily mean streamflow. This statistic is the minimum consecutive D-day mean streamflow that is expected to occur once in any Y-year period, or that has a probability of $1 / \mathrm{Y}$ of not being exceeded in any given year. The two commonly used indexes of low-flow frequencies were determined for this report: the 7-day, 2-year low-flow frequency (7Q2) and the 7-day, 10-year low-flow frequency (7Q10). The 7Q2 is the annual minimum average streamflow for 7 consecutive days that has a probability of 0.50 (1/recurrence interval) of not being exceeded in a given year. The 7Q10 is the annual minimum average streamflow for 7 consecutive days that has a probability of 0.10 of not being exceeded in a given year. The 7Q10 is commonly used in regulating waste disposal to streams by many States (U.S. Environmental Protection Agency, 1986). 


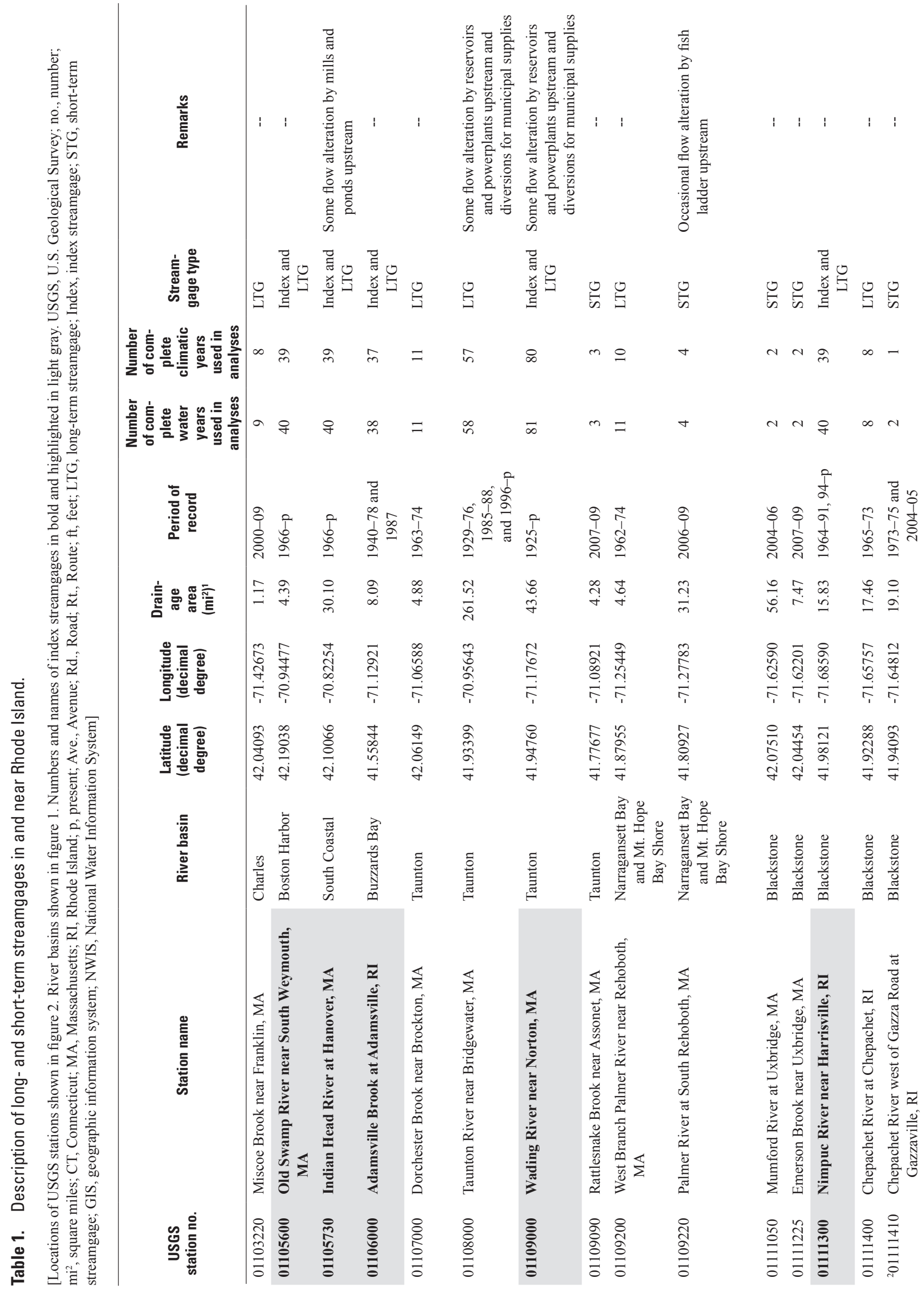




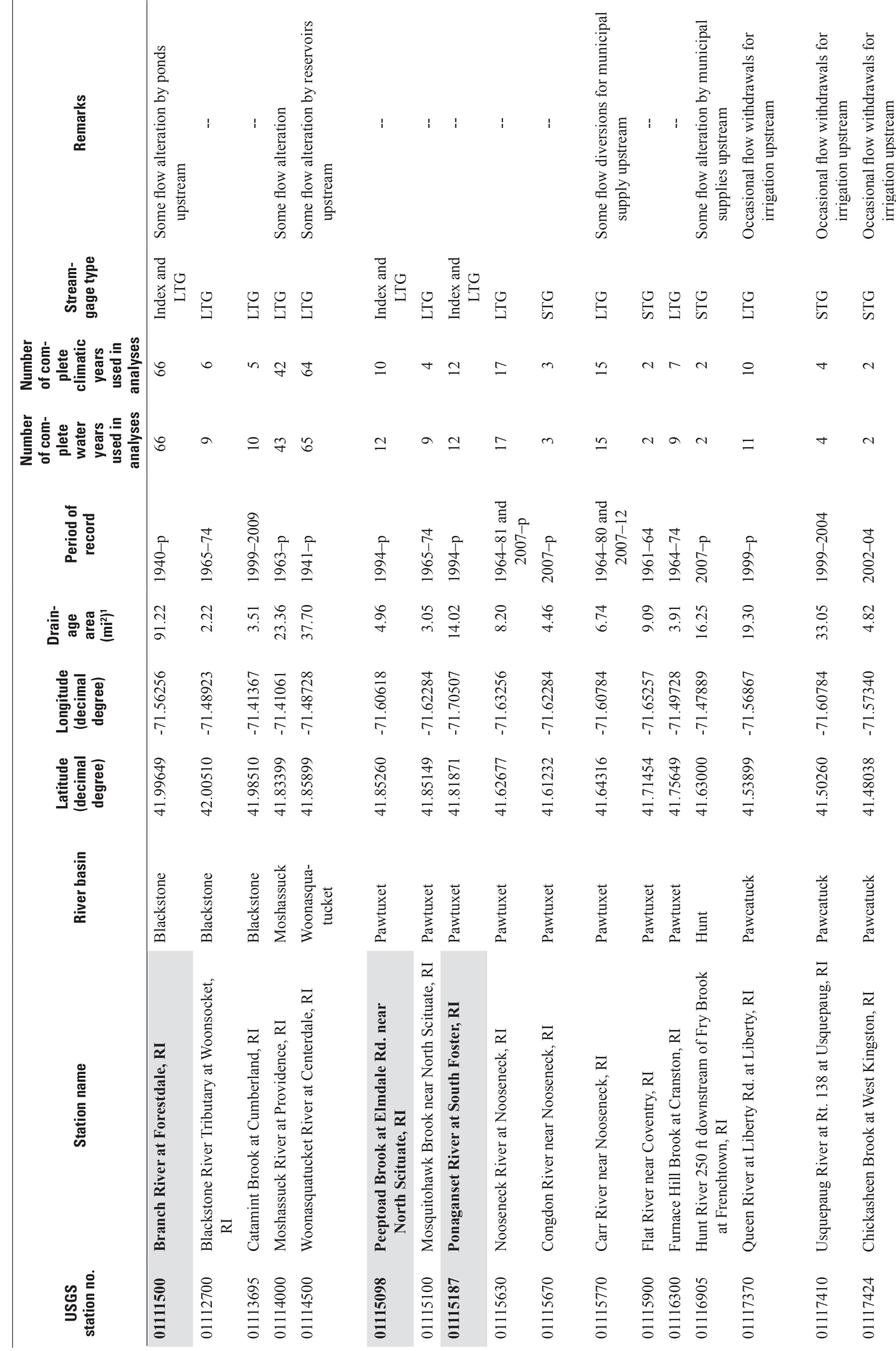




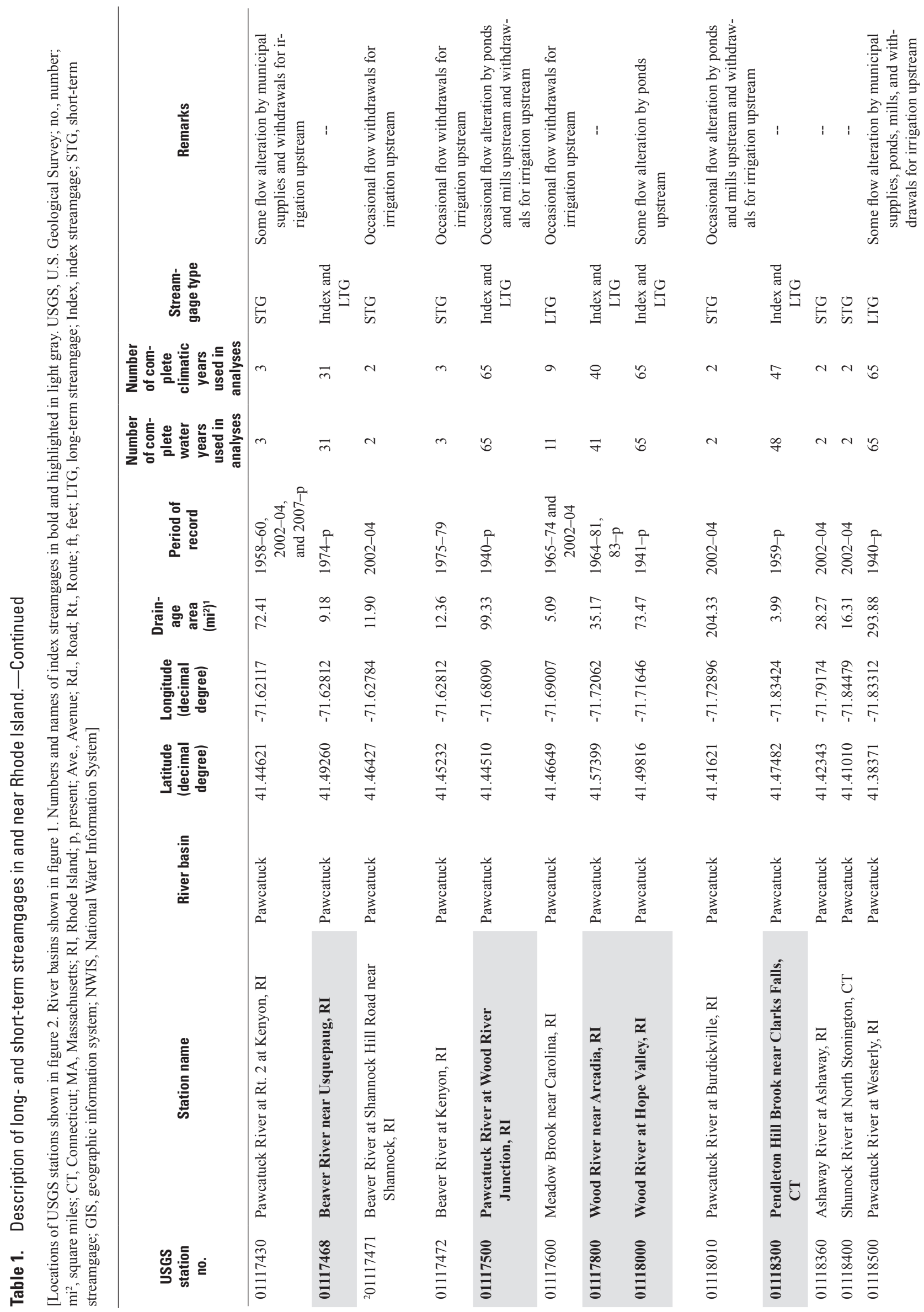




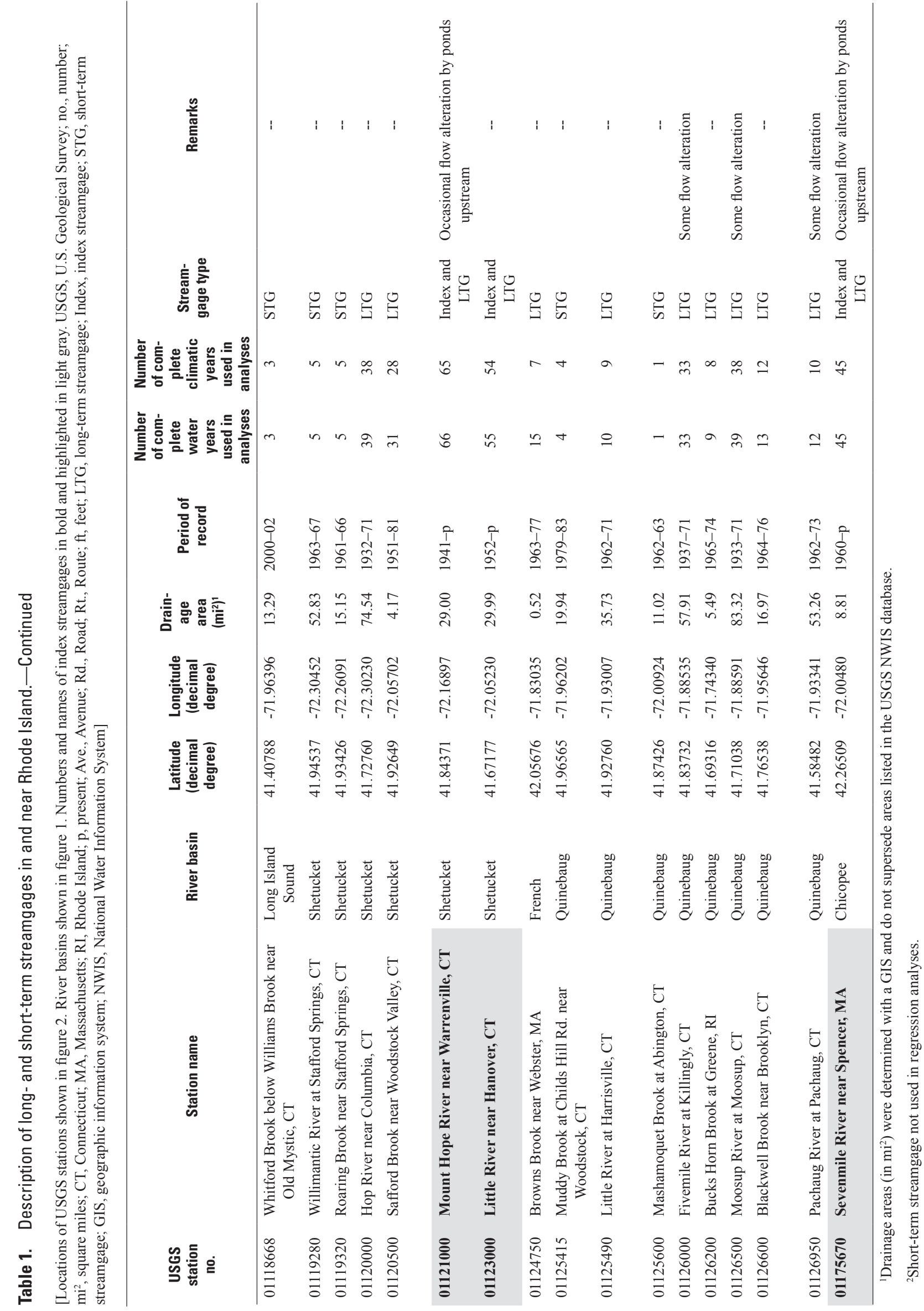




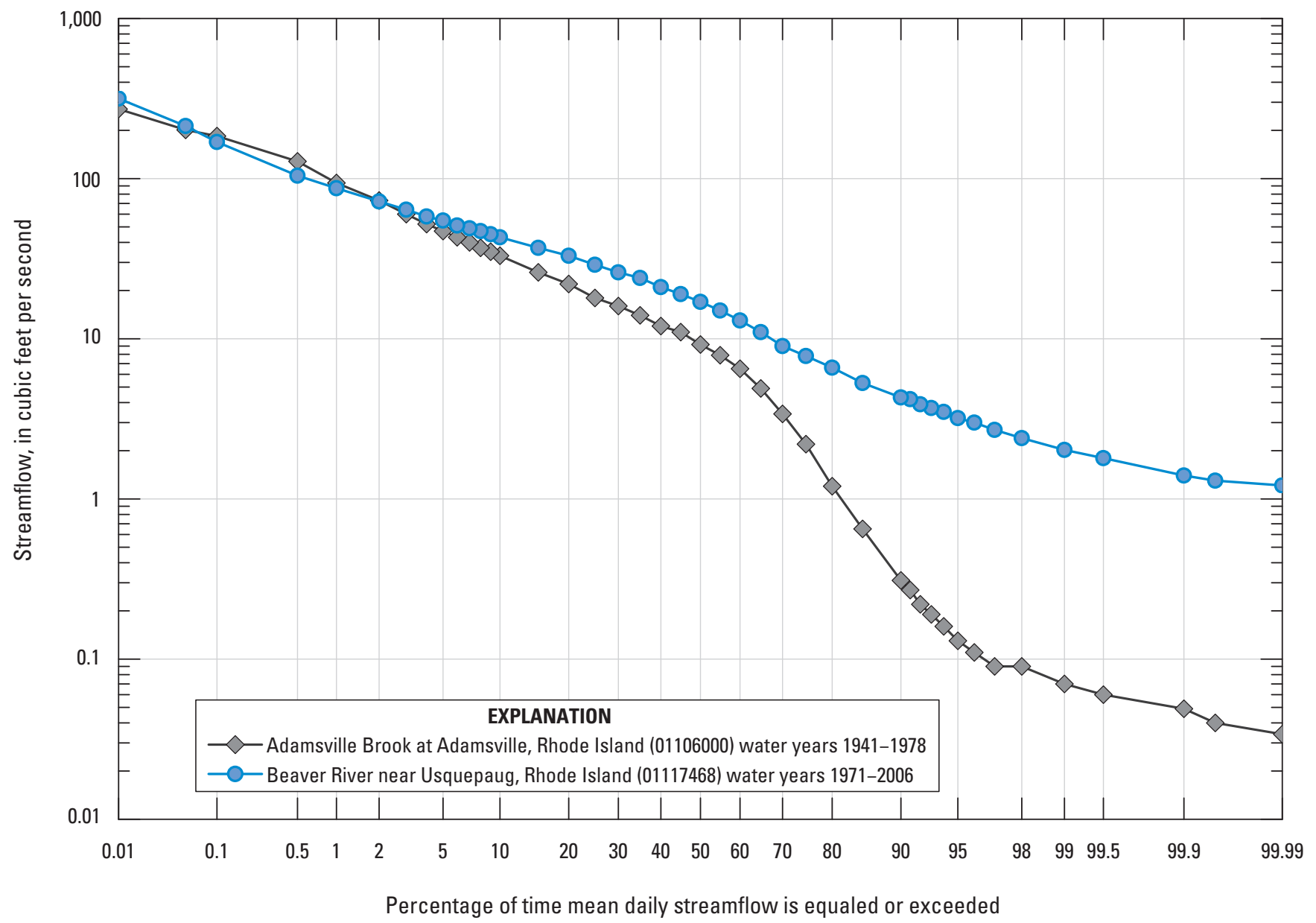

Figure 6. Flow-duration curves at the streamgages Adamsville Brook at Adamsville, R.I. (01106000), and Beaver River near Usquepaug, R.I. (01117468).

Daily streamflow data were downloaded by using the USGS database software ADAPS (Automatic Data Processing System). The streamflow data were downloaded for complete climatic years during the period of record through water year 2006. The input streamflow data were formatted, managed, and displayed by using the USGS computer software programs Input and Output for a Watershed Data Management (IOWDM) file (Lumb and others, 1990) and ANNIE (Flynn and others, 1995). The computer program Surface Water Statistics (SWSTAT) (http://water.usgs.gov/software/ SWSTAT/) (A.M. Lumb, W.O. Thomas, Jr., and K.M. Flynn, U.S. Geological Survey, written commun., 1997) was used to determine the annual low-flow frequency statistics for the USGS streamgages. SWSTAT ranks the seasonal and annual series of minimum mean n-day streamflows and then fits them to a log-Pearson Type III distribution. A resulting line of fit is then plotted through the values. The annual series were then checked for trends, but no trends were evident in the annual 7-day low flows at the long-term streamgages with more than 50 years of record. Some long-term streamgages with less than 50 years of record showed no clear trend, a slight upward trend over time, or a slight downward trend over time. The results were highly variable, and no clear trend could be identified for the annual 7-day low flows in Rhode Island. The estimated 7Q2 and 7Q10 flows for the long-term streamgages are presented in table 3. An example of the fit of the logPearson Type III distribution to the annual 7-day low flow is provided for the Branch River at Forestdale, R.I. (01111500), streamgage (fig. 7).

\section{Annual and Monthly Statistics}

The streamflow statistics mean annual, mean monthly, and median monthly streamflows also were computed by using The Nature Conservancy (2007) computer program 
Table 2. List of selected streamflow statistics computed for long- and short-term streamgages and partial-record stations in and near Rhode Island.

[Streamflow statistics for which regression equations are presented in this study are in bold and highlighted in light gray.]

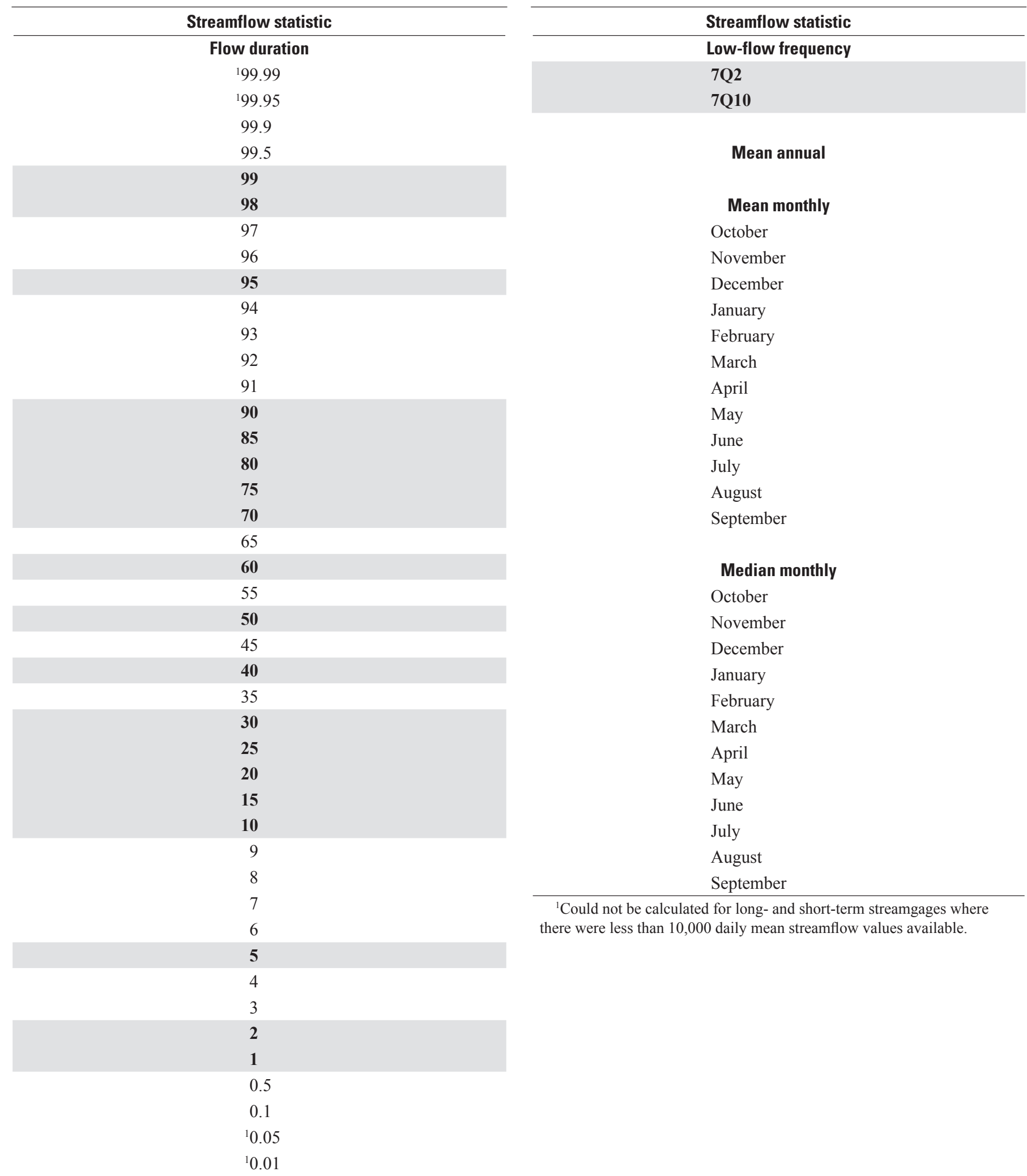




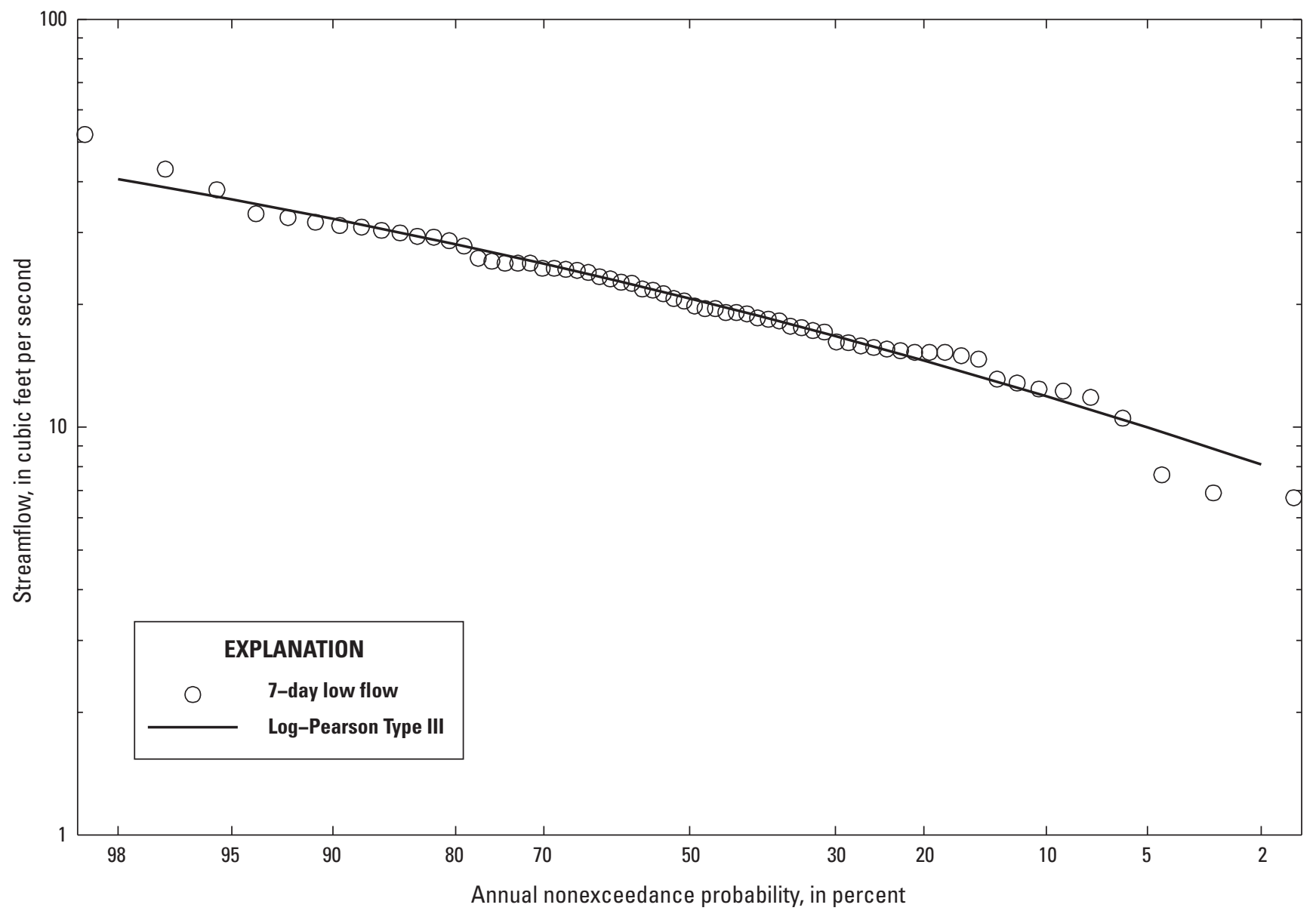

Figure 7. Example of the fit of the log-Pearson Type III distribution to the annual 7-day low flow at the streamgage Branch River at Forestdale, R.I. (01111500), for water years 1941-2006.

Indicators of Hydrologic Alteration (IHA). Data for 41 longterm streamgages (table 1 and fig. 2) were downloaded from NWISweb by using GNWISQ (Granato, 2009). Streamflow statistics were computed for 41 long-term streamgages with at least 8 or more complete water years of record (table 3 ). Eight years is the minimum length of record needed for obtaining this information. The longer a period of record for a streamgage, the more information that data can provide to the users, and the more any influence of extended wet or dry periods on the streamflow data tends to be minimized. Thus, for this study, the term "long-term streamgages" refers to those affected by little to no upstream flow alterations and with at least 8 years of record. The August median flow is an important statistical measure for fisheries and often is used for summer maintenance of aquatic habitat in New England streams (U.S. Fish and Wildlife Service, 1981).

\section{Flow Statistics for Long-Term Streamgages}

Flow statistics for long-term streamgages are critical for understanding water resources in an area, especially for those streamgages whose upstream basins included few or no flow alterations. The records from these streamgages can provide information on the variability of annual, seasonal, and daily streamflows, potential trends, low flows, and peak flows. Those long-term streamgages affected the least by upstream flow alterations and with at least 10 years of record are referred to as index streamgages. The records from index streamgages were those records determined to be acceptable for use in extending the records for short-term streamgages and partial-record stations. 


\section{Flow Statistics for Short-Term Streamgages and Partial-Record Stations}

Estimates of streamflow often are needed for short-term streamgages, whose periods of record may not represent longterm hydrologic conditions, and for partial-record stations with only a limited number of streamflow measurements. Through correlation and streamflow-record extension techniques, streamflow statistics for the short-term streamgages and partial-record stations can be estimated. Estimates can be made on the basis of the relation between daily mean streamflows at the short-term streamgages and the concurrent daily mean streamflows at nearby index streamgages. For this study, only short-term streamgages (table 1 and fig. 2) and partialrecord stations (table 4, in back of report and fig. 8) with little to no flow alteration and, respectively, at least 1 year of record and 10 streamflow measurements, in and near Rhode Island were used. For short-term streamgages and partial-record stations, daily mean streamflows and miscellaneous streamflow measurements, respectively, are related to the concurrent daily mean streamflows at nearby index streamgages. The index streamgage selected for the relation to a short-term streamgage or partial-record station is based on proximity, similarity of the physical, land-cover, land-use, surficial-deposits, and climatological characteristics between the two sites, and the linearity and Pearson's correlation coefficient $(r)$ of the relation between streamflows. For this study, the relation is defined by use of a streamflow-record extension technique known as the Maintenance of Variance Extension, type 1 (MOVE.1) (Hirsch, 1982).

The selection of index streamgages used for estimating streamflows at short-term streamgages and partial-record stations must satisfy several criteria: (1) the flow is essentially natural (very little to no alteration), (2) most or all of the period of record coincides with that for shortterm streamgages and partial-record stations, and (3) the period of record is greater than 10 years. For this study, 16 long-term streamgages were identified as possible index streamgages (table 1 and fig. 2). Of the 16 index streamgages, 9 were located in Rhode Island, 3 in Connecticut, and 4 in Massachusetts. Only the Adamsville Brook at Adamsville, R.I. (01106000), streamgage is not currently (2014) operated. After this streamgage was discontinued in 1978, it was operated continuously for part of the 1987 water year, and concurrent streamflow measurements were made (on the same day) during water years 1992-93 and 2003-04 with streamflow measurements at nearby partial-record stations.

Scatterplots of log-transformed streamflow at each short-term streamgage and partial-record station in relation to concurrent log-transformed daily mean streamflow at each of the 16 index streamgages were made by using Microsoft Excel and the computer program SREF (Granato, 2009) to determine the nature and quality of the relations between the streamflows. For partial-record stations with zero-flow measurements, a value of 0.01 cubic feet per second $\left(\mathrm{ft}^{3} / \mathrm{s}\right)$ for the zero-flow measurement was used for computation of the logarithms. Graphical plots of the relations of the data were evaluated to make sure they were linear. Generally, the relation with the highest correlation coefficient between the streamflows at the short-term streamgage or partial-record station and the index streamgage was used. For this study, the MOVE.1 technique (Hirsch, 1982) was then used to provide an equation that related streamflow at the short-term streamgage or partial-record station to the concurrent streamflow at the index streamgage. The MOVE. 1 equation is

$$
Y_{i}=Y+\frac{S y}{S x}\left(X_{i}-X\right)
$$

where

$Y_{i} \quad$ is the streamflow or streamflow statistic at the short-term streamgage or partial-record station,

$X_{i} \quad$ is the streamflow or streamflow statistic at the index streamgage,

$Y \quad$ is the mean of the daily mean streamflows or streamflow measurements at the shortterm streamgage or partial-record station, respectively,

$X$ is the mean of the concurrent daily mean streamflows at the index streamgage,

$S_{y} \quad$ is the standard deviation of the daily mean streamflows or streamflow measurements at the short-term streamgage or partialrecord station, respectively, and

$S_{x} \quad$ is the standard deviation of the concurrent daily mean streamflows at the index streamgage.

The streamflow data used in the MOVE. 1 equation is base-10 $\log$ transformed, and the resulting streamflow $\left(Y_{i}\right)$ must then be re-transformed back to arithmetic units.

Examples of the MOVE.1 relation for the short-term streamgage Chickasheen Brook at West Kingston, R.I. (01117424), to the index streamgage Beaver River near Usquepaug, R.I. (01117468), and for the partial-record station Burnt Swamp Brook near Grant Mills, R.I. (01113670), to the index streamgage Wading River near Norton, Mass. (01109000), are shown in figures 9 and 10, respectively.

Streamflow statistics were estimated by using the MOVE. 1 record-extension technique for 21 short-term streamgages (table 1 and fig. 2) and 135 partial-record stations in and near Rhode Island (table 4, in back of report and fig. 8). The index streamgage selected for estimating selected streamflow statistics at the short-term streamgage or partialrecord station, the correlation coefficient describing that relation, and the number of data points used in the analyses are listed in table 5 (in back of report). Additionally, information about the relation between the sites, such as the minimum, maximum, and range of the flow duration(s) for which a daily mean streamflow at a short-term or streamflow measurement at a partial-record station were used in the analysis, also 


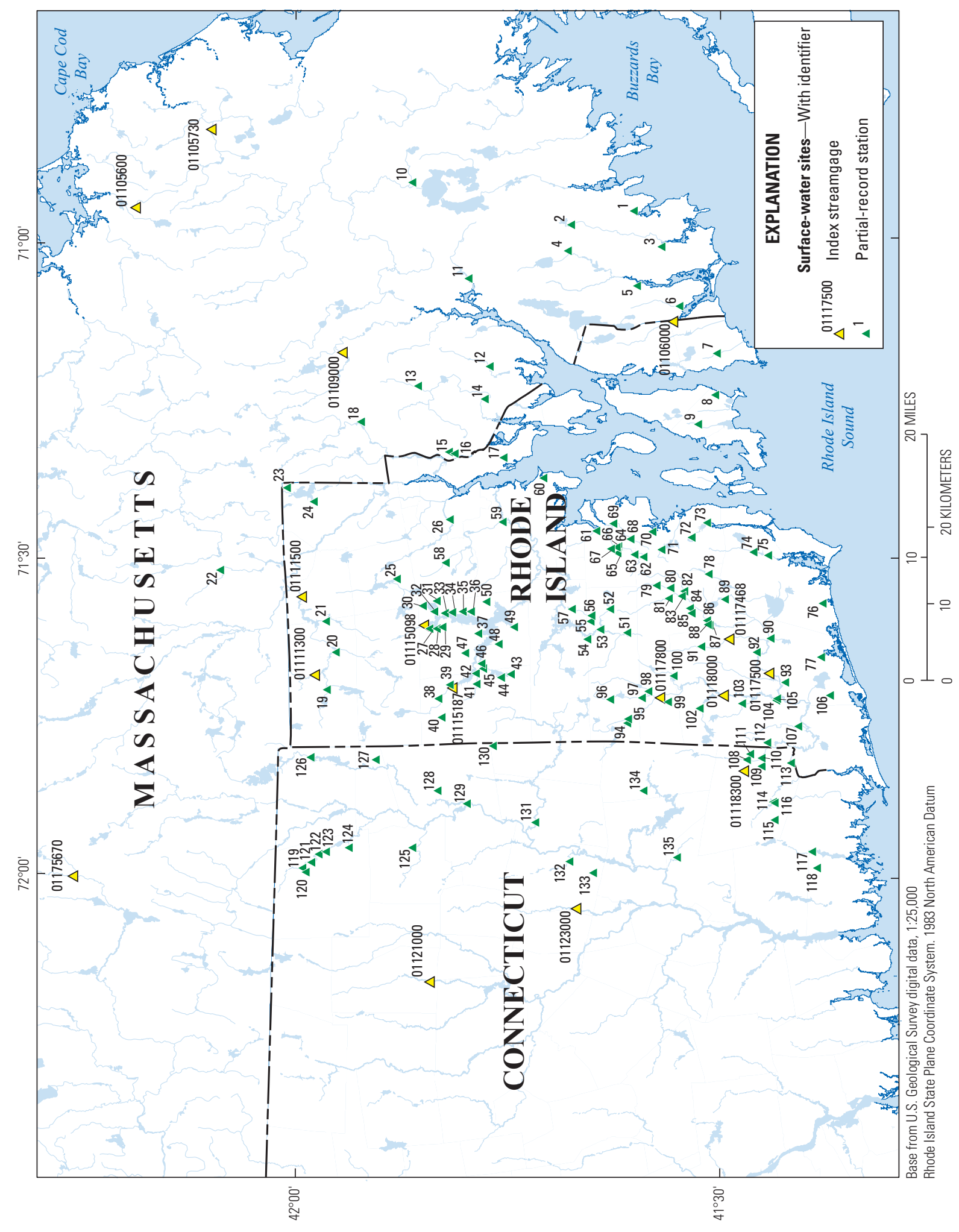

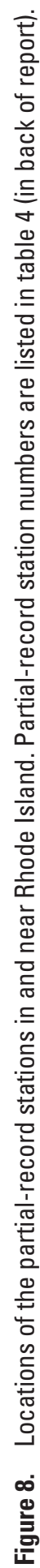




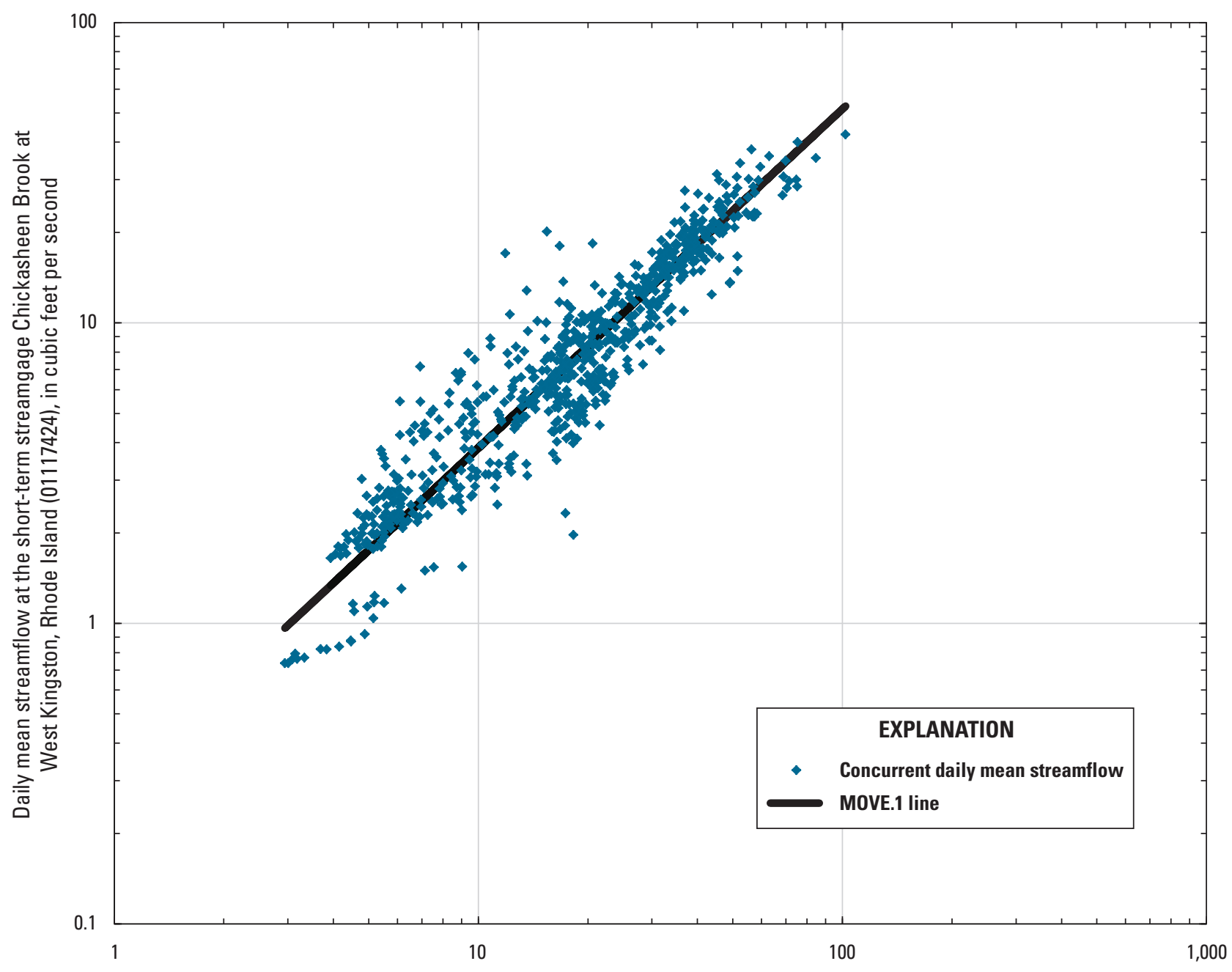

Daily mean streamflow at index streamgage Beaver River near Usquepaug, Rhode Island (01117468), in cubic feet per second

Figure 9. Example of Maintenance of Variance Extension, type 1 (MOVE.1), relation between concurrent daily mean streamflows at the short-term streamgage Chickasheen Brook at West Kingston, R.I. (01117424), and the index streamgage Beaver River near Usquepaug, R.I. (01117468).

is presented in the table 5 (in back of report). Analyses for several partial-record stations in and near Rhode Island are not presented in the report because (1) the best correlation coefficients were less than 0.80 ; (2) the record had fewer than 10 streamflow measurements; (3) the streamflow measurements covered less than 50 percent of the range of the flowduration curve; or (4) known alterations in the drainage basin could have affected streamflows. Results of the estimated streamflow statistics for 21 short-term streamgages and for 135 partial-record stations are in tables 3 and 6 , respectively.

Table 6. Estimated streamflow statistics for partial-record stations in and near Rhode Island.

[Available separately at http://pubs.usgs.gov/sir/2014/5010/ tables/sir2014-5010_bent_table06.xlsx]

\section{Basin Characteristics for Streamgages and Partial-Record Stations}

The characteristics of streamflow are directly related to a drainage basin's physical, land-cover, land-use, geologic, and climatic characteristics. Characteristics of the drainage basin were selected for use as potential explanatory variables in the regression analysis on the basis of their theoretical relations to streamflows, the results of previous streamflow studies in similar hydrologic regions, and the feasibility of determining the basin characteristics with digital datasets and GIS technology. Measuring the basin characteristics with GIS technology facilitates automation of the process and the process of solving the regional regression equations by using the USGS StreamStats Web-based application. 


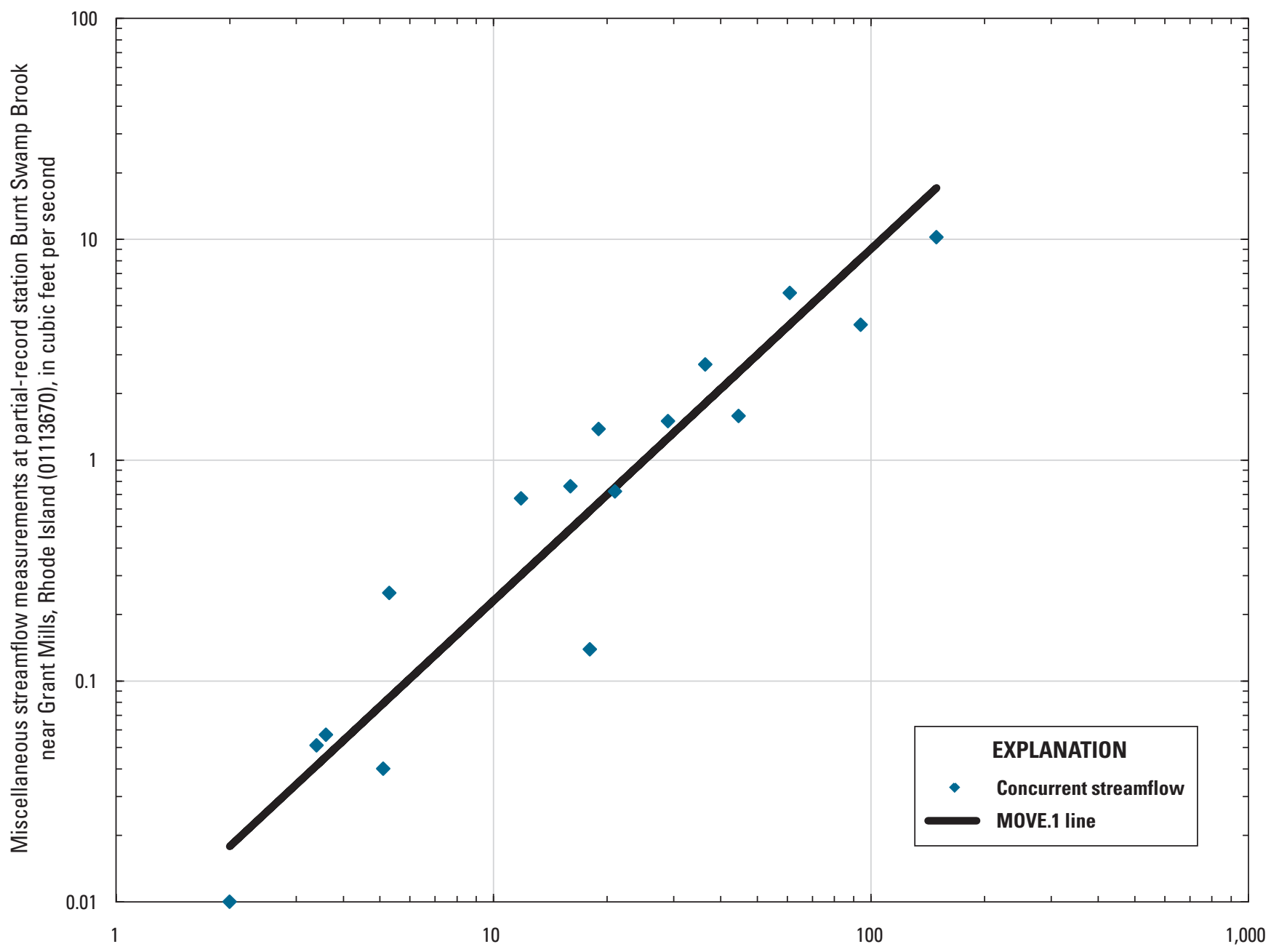

Daily mean streamflow at index streamgage Wading River near Norton, Massachusetts (01109000), in cubic feet per second

Figure 10. Example of Maintenance of Variance Extension, type 1 (MOVE.1), relation between concurrent miscellaneous streamflow measurements at the partial-record station Burnt Swamp Brook near Grant Mills, R.I. (01113670), and daily mean streamflows at the index streamgage Wading River near Norton, Mass. (01109000).

The geospatial data layers for calculation of basin characteristics are as follows: (1) total length of streams data are from the National Hydrography Dataset (NHD) (U.S. Geological Survey, 2007a); (2) elevation data, also used for slope calculations, are from the National Elevation Dataset (NED) (U.S. Geological Survey, 2007b); (3) land-cover and land-use data are from Rhode Island Geographic Information System (RIGIS) (Rhode Island Geographic Information System, 2008a), the Massachusetts Office of Geographic Information (MassGIS) (Massachusetts Office of Geographic Information, 2009), and the University of ConnecticutCenter for Land Use Education and Research (CLEAR) (University of Connecticut - Center for Land Use Education and Research, 2007a); (4) impervious-cover data are from RIGIS (Rhode Island Geographic Information System, 2008b), MassGIS (Massachusetts Office of Geographic Information, 2007a), and CLEAR (University of Connecticut - Center for
Land Use Education and Research, 2007b); (5) surficialgeology data (1:24,000 scale) are from RIGIS (Rhode Island Geographic Information System, 2007), MassGIS (Massachusetts Office of Geographic Information, 2007b), and the University of Connecticut-Map and Geographic Information Center (MAGIC) (University of ConnecticutMap and Geographic Information Center, 2007); (6) soil hydrologic group data are from the Natural Resources Conservation Service (NRCS) Soil Survey Geographic database (SSURGO) (Natural Resources Conservation Service, 2007); and (7) climatic (precipitation and temperature 1971-2000) are from the Parameter-Elevation Relationships on Independent Slopes Model (PRISM) Climate Group, Oregon State University (2007). The basin boundaries for the 41 long-term and 21 short-term streamgages and 135 partialrecord stations were overlaid on areal coverages of the basin 
characteristics of interest to determine the characteristics' values for the upstream basin to each site.

A GIS database was set up to store the characteristics of the drainage basins for the streamgages used in the regression analysis. The data layer from the NHD for total length of streams (U.S. Geological Survey, 2007a) was edited. Where a stream had more than one flow path (for example, around an island or in outlets from wetland areas), coverage was limited to only one flow path. Also, any stream segment shown crossing a basin boundary other than at the basin outlet was deleted so that all stream segments were within the basin boundary. This data layer for edited total length of streams was used with the basin characteristic data for drainage area (represented by the variable DRNAREA ${ }^{3}$ ) to determine the basin characteristic data for stream density (represented by the variable STRDENED ${ }^{3}$ ), which is the edited total length of streams divided by the drainage area. The names, units of measure, and sources of data for each measured basin characteristic are listed in table 7. The basin characteristics for long- and shortterm streamgages and partial-record stations are in tables 8 and 9 , respectively.

Table 8. Basin characteristics for long- and short-term streamgages in and near Rhode Island.

[Available separately at http://pubs.usgs.gov/sir/2014/5010/ tables/sir2014-5010_bent_table08.xlsx]

Table 9. Basin characteristics for partial-record stations in and near Rhode Island.

[Available separately at http://pubs.usgs.gov/sir/2014/5010/ tables/sir2014-5010 bent table09.xlsx]

\section{Equations for Estimating Selected Streamflow Statistics}

Streamflow information for ungaged sites is critical for Federal, state, county, city, and town agencies; nongovernmental and private organizations; and individuals and public groups dealing with water-resources issues. Flowfrequency and duration-streamflow statistics for streams at ungaged sites can be estimated by using several methods. These methods include (1) a drainage-area ratio and (2) a regression equation relating streamflow statistics to basin characteristics. Additionally, streamflow statistics may be estimated for an ungaged site with at least 10 miscellaneous streamflow measurements by the correlation of measured streamflows with concurrent daily mean streamflows at nearby continuous-record streamgages (index streamgages) followed by the streamflow-record-extension technique known as the Maintenance of Variance Extension, type 1 (MOVE.1) (Hirsch, 1982).

${ }^{3}$ USGS StreamStats basin-characteristics label (http://streamstatsags.cr.usgs. gov/ss_defs/basin_char_defs.aspx).

\section{Drainage-Area Ratio Methods}

The drainage-area ratio method is based on the assumption that the streamflow at an ungaged site is the same per unit drainage-basin area as that at a nearby hydrologically similar streamgage with little to no flow alteration of the upstream basin. Drainage areas to the ungaged site and the streamgage are determined from topographic maps or the USGS StreamStats web application (http://streamstats.usgs.gov/index. $\mathrm{html}$ ). Streamflow statistics are computed for the streamgage, and then the statistics (streamflow values) are divided by the drainage area to determine the streamflow for each statistic per unit area in cubic feet per second per square mile $\left(\mathrm{ft}^{3} / \mathrm{s} / \mathrm{mi}^{2}\right)$ at the streamgage. These values are multiplied by the drainage area to the ungaged site to obtain estimated statistics for that site. This method is most commonly applied if the index streamgage is on the same stream as the ungaged site because the accuracy of the method depends on the proximity of the two sites, on similarities in drainage area, and on other physical and climatic characteristics of their drainage basins.

Several studies have provided estimates of the maximum difference in drainage areas for which the use of the drainagearea ratio method would generate more accurate estimates of streamflow statistics than the use of regression equations. Guidelines have been provided for estimating peak-flow statistics, and usually the recommendation has been that the drainage area to the ungaged site should be 0.5 to 1.5 times the drainage area to the index streamgage (Choquette, 1988, p. 41; Koltun and Roberts, 1990, p. 6; Lumia, 1991, p. 34; Bisese, 1995, p. 13; Koltun and Whitehead, 2002, p. 22; and Martin and Arihood, 2010, p. 28). One report (Koltun and Schwartz, 1987, p. 32) recommended a narrower range of 0.85 to 1.15 times the drainage area of the index streamgage for estimating low flows at ungaged sites in Ohio. Ries and Friesz (2000), however, determined that the drainage-area ratio method could be used to estimate low-flow statistics for ungaged sites in Massachusetts if the drainage area for an ungaged site was between 0.3 and 1.5 times the drainage area of the index streamgage site. They found that this method was generally as accurate as or more accurate than regression equations for this range of drainage areas.

In the drainage-area ratio method, the streamflow values are transferred from a streamgage to the ungaged site by the following formula:

$$
Q_{u}=Q_{g} \times\left(\frac{D R N A R E A_{u}}{D R g N A R E A_{g}}\right)
$$

where

$Q_{u} \quad$ is the estimated streamflow at the ungaged site,

$Q_{g} \quad$ is the streamflow at the streamgage,

$D R N A R E A_{u} \quad$ is the drainage area at the ungaged site, and $D_{R N A R E A_{g}}$ is the drainage area at the streamgage. 
Table 7. List of basin characteristics determined for long- and short-term streamgages and partial-record stations in and near Rhode Island.

[The geospatial datalayers for calculation of basin characteristics are as follows: total length of streams data are from an edited version of the National Hydrography Dataset (U.S. Geological Survey, 2007a); elevation data, also used for slope calculations, are from the National Elevation Dataset (NED) (U.S. Geological Survey, 2007b); land-cover and land-use data (2003/2004) are from the Rhode Island Geographic Information System (RIGIS) (Rhode Island Geographic Information System, 2008a), the Massachusetts Office of Geographic Information (MassGIS) (Massachusetts Office of Geographic Information, 2009), and the University of Connecticut Center for Land Use Education and Research (CLEAR) (University of Connecticut Center for Land Use Education and Research, 2007a); impervious-cover data are from RIGIS (Rhode Island Geographic Information Systems, 2008b), MassGIS (Massachusetts Geographic Information System, 2007a), and CLEAR (University of Connecticut Center for Land Use Education and Research, 2007b); surficial-geology data (1:24,000 scale) are from RIGIS (Rhode Island Geographic Information System, 2007), MassGIS (Massachusetts Office of Geographic Information, 2007b), and the University of Connecticut Map and Geographic Information Center (MAGIC) (University of Connecticut Map and Geographic Information Center, 2007); soil hydrologic group data are from the Natural Resources Conservation Service (NRCS) Soil Survey Geographic database (SSURGO) (Natural Resources Conservation Service, 2007); and climatic data (precipitation and temperature 1971-2000) are from the Parameter-Elevation Relationships on Independent Slopes Model (PRISM) Climate Group, Oregon State University (2007). NAVD 88, North American Vertical Datum of 1988; NAD 83, North American Datum of 1983]

\section{Physical characteristics}

Drainage area (DRNAREA ${ }^{1}$ ), in square miles

Basin perimeter, in miles

Total length of streams, in miles

Stream density (STRDENED ${ }^{1}$ ) (total length of streams divided by drainage area), in miles per square mile

Stream slope between 10 and 85 percent of the main channel river length, in percent

Mean basin slope, in percent

Maximum basin elevation, in feet relative to NAVD 88

Minimum basin elevation, in feet relative to NAVD 88

Mean basin elevation, in feet relative to NAVD 88

Basin relief (maximum minus minimum basin elevation), in feet

Basin outlet elevation, in feet relative to NAVD 88

Basin centroid location - easting, state plane feet, relative to NAD 83

Basin centroid location - northing, state plane feet, relative to NAD 83

Basin outlet location - easting, state plane feet, relative to NAD 83

Basin outlet location - northing, state plane feet, relative to NAD 83

\section{Areal proportions of land-cover, land-use, and surficial-deposits characteristics}

Forested land, in percent

Agricultural land, in percent

Water bodies, in percent

Forested wetlands, in percent

Nonforested wetlands, in percent

Total wetlands (forested and nonforested), in percent

Impervious land, in percent

Urban land (high-density residential, commercial, industrial, and transportation land use), in percent

Sand and gravel deposits, in percent

NRCS SSURGO soil hydrologic groups A, B, C, and D, in percent

\section{Climatological characteristics}

PRISM Precipitation 1971-2000, drainage-basin average for mean annual, in inches

PRISM Temperature 1971-2000, drainage-basin average for mean annual maximum, in degrees Celsius

${ }^{1}$ USGS Streamstats basin characteristics label (http://streamstatsags.cr.usgs.gov/ss_defs/basin_char_defs.aspx). 
Eash and Barnes (2012) did a comparison of estimates of the 7-day 10-year low flow by using regional regression equations, the drainage-area ratio method, and the weighted drainage-area ratio method to estimates from streamflow records for 48 streamgages (31 pairs of streamgages) on the same rivers in Iowa. They found that the weighted drainagearea ratio provided the best estimate if the drainage area to the ungaged site was between 0.4 and 1.5 times the drainage area to the streamgage.

In the weighted drainage-area ratio method, the streamflow values are transferred from a streamgage to the ungaged site by using the following formula:

$$
Q_{u w}=Q_{u r} \times\left(\left(\frac{Q_{g s}}{Q_{g r}}\right)-\left(\frac{2 \times|D R N A R E A| \times\left(\left(\frac{Q_{g s}}{Q_{g r}}\right)-1\right)}{D R N A R E A_{g}}\right)\right)
$$

where

$Q_{u w} \quad$ is the weighted estimated streamflow at the ungaged site,

$Q_{u r} \quad$ is the streamflow at the ungaged site estimated from the regression equation,

$Q_{g s} \quad$ is the streamflow at the streamgage estimated from measured data,

$Q_{g r} \quad$ is the streamflow at the streamgage estimated from the regression equation,

$|D R N A R E A| \quad$ is the absolute value of the difference between the drainage areas to the streamgage (DRNAREA $\left.A_{g}\right)$ and the ungaged site (DRNAREA ${ }_{u}$,

$D R N A R E A_{g} \quad$ is the drainage area to the streamgage, and $D_{R N A R E A}{ }_{u} \quad$ is the drainage area to the ungaged site.

As $\frac{Q_{g s}}{Q_{g r}}$ approaches 1, or the difference in drainage areas approaches 50 percent, the weighting factor approaches 1 and no longer has an effect on the regression equation estimate for the ungaged site. Additionally, both the drainage-area and weighted drainage-area ratio methods may not be applicable for ungaged sites where changes in the physical, land-cover, land-use, surficial-deposits, or climatological characteristics or alterations to streamflows between the ungaged site and the streamgage are substantial. The error associated with estimates based on the drainage-area and weighted drainage-area ratio methods can not be calculated.

\section{Regional Regression Analyses}

Studies to develop regional regression equations for estimating streamflow statistics at ungaged sites have been done in many states throughout the U.S. and specifically in the states adjacent to Massachusetts. Multiple regression analyses provide a mathematical equation for estimating a response (dependent) variable - streamflow statistic - from one or more explanatory (independent) variable(s), such as basin characteristics. Ideally, the development of regression equations involves the use of streamflow data from a large number of long-term streamgages on unaltered streams evenly distributed across the region of interest and with a range of basin characteristics. But in many cases, the number of streamgages representing unaltered flow is limited, the streamgage network is often biased toward representing larger streams or rivers, the network is unevenly distributed geographically, and the range of basin characteristics upstream of streamgages does not cover the complete range found in the region. In Rhode Island, the number of streamgages on streams with little to no flow alteration is limited; for this reason, nearby streamgages in eastern Connecticut and southeastern and south-central Massachusetts were also included. The records for these streamgages were used to develop regional regression equations for estimating selected streamflow statistics at ungaged sites in Rhode Island.

Multiple regression is used to create equations that relate streamflow statistics for streamgages to the physical, landcover, land-use, surficial-deposit, and climatological characteristics of their upstream drainage areas. Once an optimal equation has been determined, a streamflow statistic at a nearby ungaged site in a basin with similar characteristics can then be estimated by applying the equation to the ungaged site.

The basic equation describing a linear multiple regression analysis is

$$
Y_{i}=b_{0}+b_{1} X_{1}+b_{2} X_{2}+\ldots+b_{n} X_{n}+e_{i}
$$

where

$$
\begin{aligned}
& Y_{i} \quad \text { is the response (dependent) variable } \\
& \text { (estimated streamflow statistic) for the } \\
& \text { ungaged site } i \text {, } \\
& b_{0} \text { to } b_{n} \text { are the coefficients determined in the analysis, } \\
& X_{i} \text { to } X_{n} \quad \text { are the explanatory (independent) variables } \\
& \text { (basin characteristics) for the ungaged site } \\
& i \text {, and } \\
& e_{i} \quad \text { is the residual error or difference between the } \\
& \text { observed and estimated response variables } \\
& \text { for ungaged site } i \text {. }
\end{aligned}
$$

Linear regression analysis is based on the following assumptions: (1) the mean of the residuals $\left(e_{i}\right)$ is zero, $(2)$ the variance of the residuals is constant, (3) the residuals are normally distributed, and (4) the residuals are independent of each other. In addition to these assumptions, the selected explanatory variables $(X)$ should have a physical basis as predictors of the streamflow statistic, the explanatory variables (basin characteristics) in the equation should not be highly correlated with each other, and the signs of the terms of the equation should make hydrological sense. For example, the variable drainage area should have a positive coefficient because an 
increase in drainage area should result in an increase in the value of the streamflow statistic.

In almost all regionalization studies to determine lowflow and peak-flow statistics, the response and explanatory variable datasets are skewed. As a consequence, the data need to be transformed to ensure that the mean of the residuals equals zero. In many studies, a logarithmic transformation is used. A base10 log-transformed multiple regression equation has the form

$$
\log Y_{i}=b_{0}+b_{1} \log X_{1}+b_{2} \log X_{2}+\ldots+b_{n} \log X_{n}+e_{i} .
$$

After the coefficients have been determined through regression analysis, the equation is transformed back to its original units in a form that can be used to estimate a specific streamflow statistic at an ungaged site. The retransformed equation has the following form:

$$
Y_{i}=10^{b_{0}}+X_{1}^{b_{1}}+X_{2}^{b_{2}}+\ldots+X_{n}^{b_{n}}+10^{e_{i}}
$$

A linear regression equation provides an unbiased estimate of the mean response of the response variable. Although estimates provided by equation 5 are unbiased, these estimates are in log units, whereas estimates in the original units are needed to calculate specific streamflow statistics at an ungaged site. Estimates from equation 6 are in the original units. However, this equation predicts the median, instead of the mean, value of the response variable. A streamflow statistic based on a median creates an estimate that is biased and tends to be lower than the mean (Ries and Friesz, 2000). Bias correction factors (BCFs) were used in some studies in Massachusetts and New Hampshire to remove the bias from the estimate (Ries, 1994a and b; Ries and Friesz, 2000; Flynn, 2003a and b, and Archfield and others, 2010). In other studies (Risley, 1994; Stuckey, 2006; Armstrong and others, 2008; and Ahearn, 2010), BCFs were not used, likely because they were generally very small. In this study, BCFs were also not used, because if they were, then the streamflows estimated from the regression equations would not have an equal chance of being higher or lower than their actual values (Julie Kiang, U.S. Geological Survey, oral commun., 2011).

\section{Development of Regression Equations}

In regional regression studies, explanatory and response variables often need to be transformed before the regression equation is created to ensure a linear relation. Scatterplots, correlation tables, and linear regression analyses were done by applying the statistical software Minitab (2003) to the selected streamflow statistics at long-term and short-term streamgages (table 3 ) and the basin characteristics (table 8 ) to determine if variable transformations were needed. The scatterplots indicated that a $\log$ transformation was needed to meet the assumptions of linear regression. Thus, the logarithmic (base-10) transformation was selected and applied to streamflow statistics (response variables) and basin characteristics (explanatory variables) to linearize the relation between the explanatory variables and the response variables, to ensure equal variance about the regression line, and to decrease the spread of the data.

Several potential explanatory variables (basin characteristics) for the drainage basin upstream of a few streamgages had one or a few values of zero. The variables were generally limited to land-cover, land-use or surficial deposits characteristics of the drainage basin, such as forested land, water bodies, wetlands, impervious land, and sand and gravel deposits. To logarithmically (base-10) transform all the values of that basin characteristic, a constant value of $0.01,0.10$, or 1.00 (depending on the lowest values other than the zero values) was added to all values of that basin characteristic.

Scatterplots of logarithmic (base-10) transformed basin characteristics were then examined to determine if particular characteristics were correlated with other characteristics $(r)$ (table 10). If two basin characteristics were found to have a moderate or strong correlation (an absolute value of Pearson's $r$ greater than or equal to 0.50 ), then those basin characteristics were tested separately in the variable-selection process of the regression analyses. This separate testing was done to eliminate redundant basin characteristics in the variable-selection process. For example, the basin characteristics denoted as "drainage area" and "total length of streams" had very strong correlations of $r=0.98$ and higher (table 10). For this reason, these basin characteristics were tested separately in the variable-selection process.

Table 10. Pearson's correlation coefficients for basin characteristics evaluated as potential explanatory variables for regression equations for estimating selected streamflow statistics for long- and short-term streamgages in Rhode Island.

\section{[Available separately at http://pubs.usgs.gov/sir/2014/5010/ tables/sir2014-5010_bent_table10.xlsx]}

For the initial regression analyses of the selected potential explanatory variables, the automated statistical procedures called "best subsets" and "stepwise" were used in Minitab (2003). Both selection procedures determined the statistical contribution that was entered in the equation for each of the explanatory variables (basin characteristics), and variables were retained or deleted based on their statistical importance.

In the procedure "best subsets" (Minitab, 2003), the two equations with the highest coefficients of determination $\left(R^{2}\right)$, the Mallow's $C p$ closest to the number of explanatory variables plus the constant 1 , and the lowest root mean square errors were evaluated for each of the possible combinations of selected explanatory variables to determine the best possible combinations of the explanatory variables. The procedure identified the best two combinations of explanatory variables for models with a specified number of explanatory variables. With this procedure, each explanatory variable can be included or excluded independently of the other explanatory variables. 
Efroymson's stepwise selection procedure (Efroymson, 1960), is similar to forward selection, which involves testing explanatory variables one by one and including them in the equation if they are statistically significant; however, as each new variable is added to the subset, partial correlations are considered to determine whether any of the variables in the subset should be dropped. In the procedure "stepwise" (Minitab, 2003), the procedure essentially outputs the best potential combination of explanatory variables (which have $T$-statistic values whose absolute values are greater than or equal to 2.00 and $p$-values less than or equal to 0.05 ) for models with increasing numbers of explanatory variables until no additional variables meet the criteria for $T$-statistic values and $p$-values. Additionally for each model, $R^{2}$, Mallow's $C p$, and $s$ (root mean square error) are presented to assist in evaluation of the models. In these analyses, basin characteristics that were found to be highly correlated (absolute value of $r$ greater than or equal to 0.50 ) were entered only one at a time during the "best subsets" and "stepwise" procedures to prevent regression problems.

If the two "best subsets" and "stepwise" procedures identified the same set of basin characteristics, then the top few potential explanatory variables were further evaluated with the ordinary-least-squares (OLS) regression procedure. For the explanatory variables, the $p$-value, $T$-statistic value, and VIF (variance inflation factor) statistics were evaluated. For the model output parameters $R^{2}, s$, PRESS statistic, unusual observations (large standard residuals and (or) $\mathrm{X}$ values with large influence), and the Durbin-Watson statistic were evaluated. The histogram, normal probability, and graphs of the residuals as functions of the fitted values and the order of the data also were evaluated. Additionally, the statistic named "high influence," the Cook's Distance statistic, and the DFITS statistic were evaluated.

After the evaluation of selected streamflow statistics estimated for the short-term streamgages (table 3) and partialrecord stations (table 6), only the short-term streamgages were selected for inclusion with the 41 long-term streamgages for the regression analysis. Two of the 21 short-term streamgages were not included in the regression analyses because the record for another streamgage nearby on the same river was longer, and the drainage areas and basin characteristics of the two streamgages were similar. Exclusion of these two streamgages removed redundancy of those streamflow statistics and basin characteristics in the regression analyses. The two short-term streamgages excluded were Chepachet River near Gazzaville, R.I. (01111410), and Beaver River at Shannock Hill Road near Shannock, R.I. (01117471) (fig. 2).

The partial-record stations were not included in the regression analyses because of several factors:

1. The 135 partial-record stations had from 11 to 87 streamflow measurements for use in the MOVE.1 relation with an index streamgage for estimating long-term streamflow statistics, whereas a 1-year of continuous record at a streamgage would provide 365 daily mean streamflow values for use in the MOVE. 1 relation with an index streamgage for estimating long-term statistics.

2. Weighting procedures for partial-record stations have differed among previous studies. For example, Stuckey (2006) assigned 1 year of record to partial-record stations for every year when a streamflow measurement was made, whereas Ahearn (2010) assigned 5 years of record to partial-record stations for every year when a measurement was made. Either of these weighting procedures could result in more years of record for a partial-record station than for a short-term streamgage which was operated for 1 or more years. If the number of streamflow measurements for a partial-record station were divided by 365 days, the partial-record station would have so little weight that its effect in the regression analyses would be negligible.

3. Boxplots of selected basin characteristics for partialrecord stations were compared with boxplots for the longterm and short-term streamgages, and the comparison showed that the partial records did not expand the range of the basin characteristics.

4. The computer program entitled "Displaying Redundant Partial Record Sites - drprs" (Charles Berenbrock and Ken Eng, U.S. Geological Survey, written commun., 2009) was used to evaluate the data from the partialrecord stations for possible use in the regional regression analyses. Results showed that the range between the minimum and maximum values for the basin characteristics were adequately covered by data from the long- and shortterm streamgages. Additionally, the program showed that there were no areal gaps within the study area that could have been covered by the partial-record stations.

5. The regression equations might be overly influenced by estimated streamflow statistics from a large number of partial-record stations with small drainage areas.

6. The streamflow statistics for the index streamgages are already included in the regression analyses, and they also were used to estimate the long-term streamflow statistics for the short-term streamgages that are also included in the analyses.

\section{Weighting Procedures}

For flow-duration statistics, a weighted procedure similar to that used by Ahearn (2010) in Connecticut and Stuckey (2006) in Pennsylvania was used. The weight factor for the record of each streamgage used in the regression analyses was increased in proportion to the length of the record. The weight was assigned by multiplying the number of years in the period of record by the total number of streamgages in the study and dividing the product by the total number of years of record for all streamgages in the study. For example, the weight for 
the short-term streamgage Ashaway River at Ashaway, R.I. (01118360), with the equivalent of 2 years of record would be 0.0882 [ $(2$ years $\times 60$ streamgages $) \div(1,361$ total years $)$ ], whereas the weight for Adamsville Brook at Adamsville, R.I. (01106000), with the equivalent of 38 years of record would be 1.6752 [(38 years $\times 60$ streamgages $) \div(1,361$ total years $)]$.

\section{Final Regression Equations}

The response variables (flow duration and low-flowfrequency statistics) included some zero flows for the lower flow statistics at some streamgages. Of the 60 streamgages' statistics used in the regression analyses, 4 had zero flow at the 7Q10, and 99- and 98-percent flow durations. Two streamgages also had zero flow at the 7Q2 and 95-percent flow duration (table 3 ). The value of zero cannot be logarithmically transformed, but logarithmic transformation of streamflow statistics (that are not normally distributed) is needed to develop regression equations.

The method of handling the zero values in a regression analysis depends on the number of streamgages in the dataset with response variables equal to zero. If the number is sufficient, logistic regression or a Tobit model can be used (Tasker, 1989; Ludwig and Tasker, 1993; Kroll and Stedinger, 1999; Hortness, 2006). If the number is small, left-censored regression analysis, which uses an adjusted maximumlikelihood estimation (Cohn, 1988, and Helsel, 2005) or a method that adds a small constant value $(0.01,0.10$, and 1.00 ) to all response variables in a dataset, is used (Kroll and Stedinger, 1999).

Given the small number of streamgage in this study with zero-flow statistics for the 7Q10 and 7Q2 and 99-, 98-, and 95-percent flow durations, left-censored regression analyses were used to develop the regression equations for these streamflow statistics. The left-censored regression analyses were done by using USGS library S-Plus for Windows (Lorenz and others, 2011) in the program TIBCO Spotfire SPlus (TIBCO Software, Inc., 2008). This procedure in S-Plus uses the adjusted maximum-likelihood estimation, which is recommended for data that is log-normally distributed. The adjusted maximum-likelihood estimation is described by Cohn (1988) and Helsel (2005).

For the flow-duration statistics 90-, 85-, 80-, 75-, 70-, 60-, 50-, 40-, 30-, 25-, 20-, 15-, 10-, 5-, 2-, and 1-percent, the final regression equations were developed by using the user-weighted least-squares (WLS) regression technique in the weighted-multiple-linear regression (WREG) program (Eng and others, 2009).

The regression analyses determined that drainage area (represented by the variable DRNAREA) $\left(\mathrm{mi}^{2}\right)$ was a significant explanatory variable in all 21 of the regression equations. Drainage area generally is the most significant explanatory variable in all regional streamflow regression equations, whether for low flows, peak flows, mean annual, mean monthly, or median monthly statistics. The final regression equations for the 21 streamflow statistics are listed in table 11.
Stream density (STRDENED) $\left(\mathrm{mi} / \mathrm{mi}^{2}\right)$, which is the total length of streams (mi) divided by the drainage area $\left(\mathrm{mi}^{2}\right)$, also was a significant explanatory variable in all but 3 of the 21 regression equations. The three streamflow statistics for which STRDENED was not significant were the 20-, 15-, and 10 -percent flow durations. Stream density is less commonly a significant explanatory variable than drainage area but has been used in low-flow regression equations for a region of Pennsylvania (Stuckey, 2006), logistic regression equations for estimating the probability of a stream flowing perennially in Massachusetts (Bent and Archfield, 2002), and peak-flow equations for Rhode Island (Zarriello and others, 2012).

Stream density had a negative coefficient in several regression equations for estimating low flows in Pennsylvania (Stuckey, 2006) and in the logistic regression equation for estimating the probability of streams flowing perennially in Massachusetts (Bent and Archfield, 2002). Zarriello and others (2012) found stream density to have a positive coefficient in the regression equations for estimating peak flows in Rhode Island. The coefficient for STRDENED in this study changed from negative in the low-flow regression equations to positive in the high-flow equations. For example, the coefficient for STRDENED decreased from -2.29 in the equation for the 99-percent flow duration to -0.18 in the equation for the 25 -percent flow duration, and then increased from +0.18 at the 5 -percent flow duration to +0.49 at the 1 -percent flow duration (table 11). At high-flow durations, a greater stream density allows runoff to be quickly routed out of the basin (less water being available during lower flows) through its larger network of flow paths; the increasing streamflow is represented by the positive coefficient. STRDENED is not a significant explanatory variable between the 20 - and 10 -percent flow durations because the coefficient is changing from positive to negative; as a result, its effect on streamflow is minimal. At low-flow durations, a greater stream density in a basin allows base flow to be routed out of the basin earlier in the runoff recession (less base flow being available during lower flows) through its larger network of flow paths intercepting the water table; the decreasing streamflow is represented by the negative coefficient.

The standard error of the estimate for the 21 regression equations ranged from 17.58 to 141.83 percent (table 11). The low-flow statistics - the 99- to 85-percent flow durations and $7 \mathrm{Q} 2$ and 7Q10 - had higher standard errors of the estimate, ranging from 48.68 to 141.83 percent. The standard error of the estimate for the medium- to high-flow statistics - the 80- to 1-percent flow durations - ranged from 17.58 to 37.65 percent, with the standard errors for the 60- to 1-percent flow durations all being less than about 21 percent. Although the standard errors of the estimate are high for the low-flow statistics, they are similar to those calculated for regional regression equations developed to estimate low-flow statistics in Connecticut (Ahearn, 2010) and Massachusetts (Ries and Friesz, 2000). Additionally, high standard errors of the estimate for low-flow equations are common in statewide studies throughout the U.S. The user-WLS regression 
Table 11. Summary of regression equations and measures of model accuracy for estimating selected streamflow statistics in Rhode Island.

[DRNAREA, drainage area in square miles; STRDENED, drainage density in miles per square mile; WLS, weighted-least-squares regression; WREG, weighted-multiple-linear regression (Eng and others, 2009); S+, statistical software program in S programming language (TIBCO Software, Inc., 2008); --, no data available]

\begin{tabular}{|c|c|c|c|c|c|c|c|}
\hline $\begin{array}{l}\text { Stream- } \\
\text { flow } \\
\text { statistic }\end{array}$ & Regression equation & $\begin{array}{c}\text { Number } \\
\text { of } \\
\text { stations }\end{array}$ & $\begin{array}{l}\text { Standard } \\
\text { error of the } \\
\text { estimate } \\
\text { (base-10 } \\
\text { logarithm) }\end{array}$ & $\begin{array}{l}\text { Standard } \\
\text { error of the } \\
\text { estimate } \\
\text { (percent) }\end{array}$ & $\begin{array}{l}\text { Standard } \\
\text { error of } \\
\text { prediction } \\
\text { (base-10 } \\
\text { logarithm) }\end{array}$ & $\begin{array}{l}\text { Standard } \\
\text { error of } \\
\text { prediction } \\
\text { (percent) }\end{array}$ & Regression method \\
\hline \multicolumn{8}{|c|}{ Flow duration } \\
\hline 1 & 9.3325(DRNAREA) $)^{0.94}(\mathrm{STRDENED})^{0.49}$ & 60 & 0.0909 & 21.15 & 0.0915 & 21.31 & User WLS-WREG \\
\hline 5 & 5.4954(DRNAREA) $)^{0.98}(\mathrm{STRDENED})^{0.18}$ & 60 & 0.0840 & 19.52 & 0.0846 & 19.67 & User WLS-WREG \\
\hline 10 & $4.3652(\mathrm{DRNAREA})^{1.00}$ & 60 & 0.0758 & 17.58 & 0.0762 & 17.67 & User WLS-WREG \\
\hline 15 & 3.4674(DRNAREA) $)^{1.01}$ & 60 & 0.0766 & 17.78 & 0.0770 & 17.87 & User WLS-WREG \\
\hline 20 & 2.7542(DRNAREA) $)^{1.02}$ & 60 & 0.0785 & 18.22 & 0.0789 & 18.32 & User WLS-WREG \\
\hline 25 & 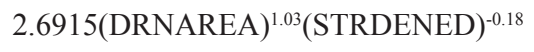 & 60 & 0.0768 & 17.83 & 0.0774 & 17.96 & User WLS-WREG \\
\hline 60 & $1.0715(\mathrm{DRNAREA})^{1.07}$ (STRDENED) $^{-0.50}$ & 60 & 0.0887 & 20.65 & 0.0894 & 20.80 & User WLS-WREG \\
\hline 70 & $0.6761(\mathrm{DRNAREA})^{1.13}(\mathrm{STRDENED})^{-0.68}$ & 60 & 0.1080 & 25.25 & 0.1088 & 25.44 & User WLS-WREG \\
\hline 75 & $0.5248(\mathrm{DRNAREA})^{1.17}(\mathrm{STRDENED})^{-0.84}$ & 60 & 0.1304 & 30.72 & 0.1314 & 30.96 & User WLS-WREG \\
\hline 80 & $0.4074(\mathrm{DRNAREA})^{1.21}(\mathrm{STRDENED})^{-1.01}$ & 60 & 0.1581 & 37.65 & 0.1593 & 37.95 & User WLS-WREG \\
\hline 85 & 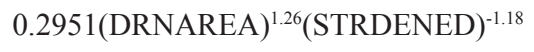 & 60 & 0.2003 & 48.68 & 0.2025 & 49.27 & User WLS-WREG \\
\hline 90 & 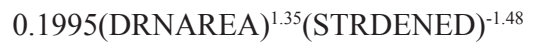 & 60 & 0.2894 & 74.76 & 0.2915 & 75.45 & User WLS-WREG \\
\hline 95 & $0.1006(\mathrm{DRNAREA})^{1.48}(\mathrm{STRDENED})^{-1.80}$ & 60 & 0.3659 & 101.67 & -- & -- & Left censored-S+ \\
\hline 98 & 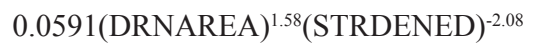 & 60 & 0.4018 & 116.35 & -- & -- & Left censored-S+ \\
\hline 99 & $0.0441(\mathrm{DRNAREA})^{1.64}(\mathrm{STRDENED})^{-2.29}$ & 60 & 0.4560 & 141.83 & -- & -- & Left censored-S+ \\
\hline
\end{tabular}

technique in the WREG program or in the left-censored regression analyses do not calculate the $R^{2}$.

A review of areal plots of the residuals (differences between streamflow statistics estimated from measured streamflow and those estimated from the regression equations) for the 7Q10 low-flow frequency and the 95-, 75-, 50-, 25-, and 5-percent flow-duration statistics at the 60 streamgages did not indicate any strong regional biases (clear groups of negative or positive residuals) (figs. 11A-F). Additionally, plots of the streamflow statistics estimated from measured streamflow (observed data) as functions of the same statistics estimated from the regression equations (predicted data) are presented in figures 12A-F. For the lower flows (7Q10 and 95-percent flow duration), the range of the data is clearly wider than that for medium and higher flows - for example, at the 50-percent flow duration (at which the flow is equal or exceeded 50 percent of the time). Again, a wide range between observed and predicted data is generally found in all studies to develop regional regression equations for estimating low flows; the higher standard errors of the estimate -48.68 to 141.83 percent - for the 99- to 85-percent flow durations and $7 \mathrm{Q} 2$ and $7 \mathrm{Q} 10$ regression equations also reflect this wide range (table 11). In figures $12 \mathrm{~A}$ and $\mathrm{B}$ (7Q10 and 95-percent flow durations, respectively), the data for streamflows less than $0.10 \mathrm{ft}^{3} / \mathrm{s}$ clearly show a wide range. For streamflows less than $0.10 \mathrm{ft}^{3} / \mathrm{s}$ there is possibly a small bias towards the regression equations, which generated values higher than the measured streamflows. In addition, the values for streamflows greater than about $50 \mathrm{ft}^{3} / \mathrm{s}$ indicate a small amount of bias towards the regression equations. In the other plots for the 


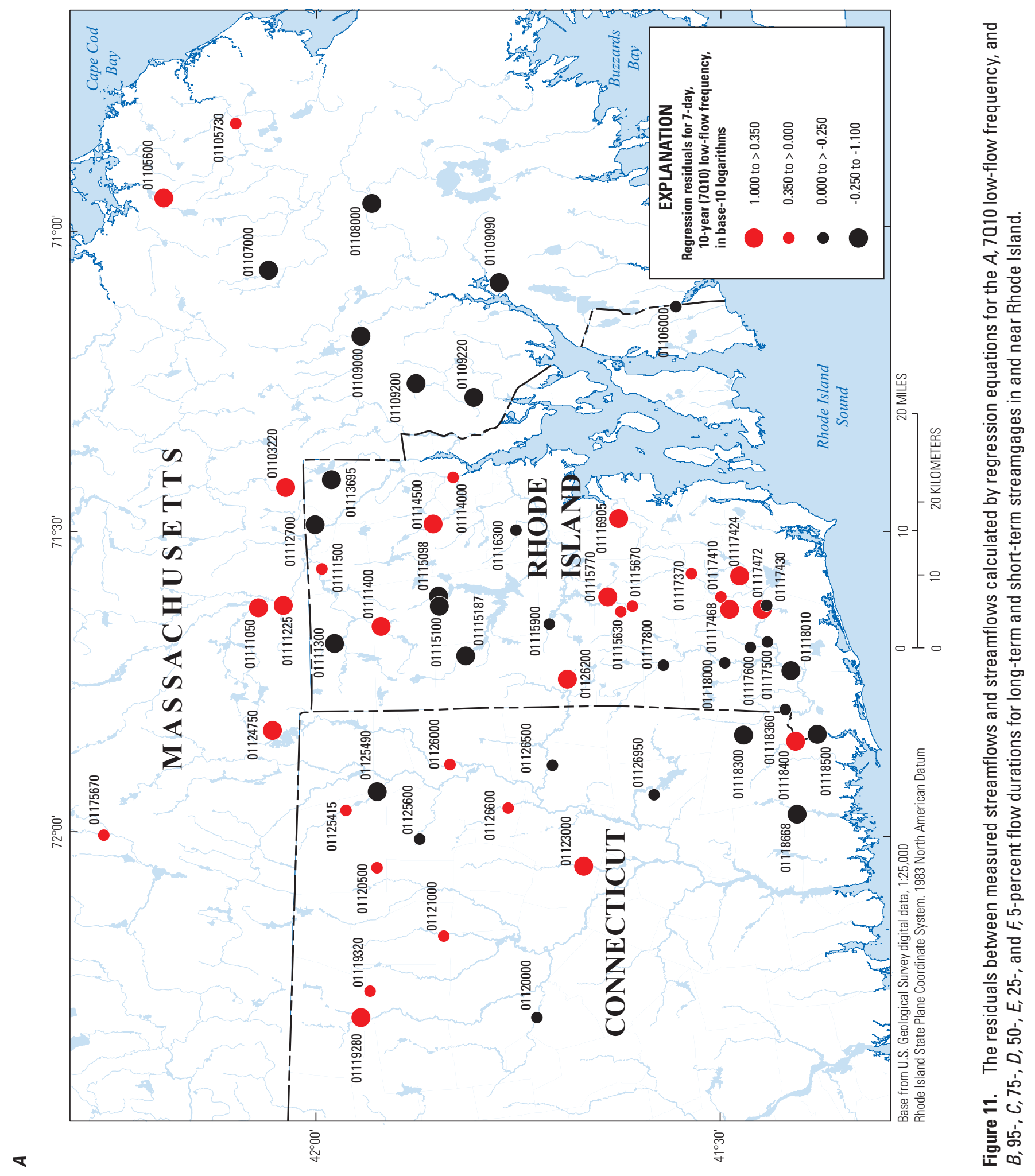




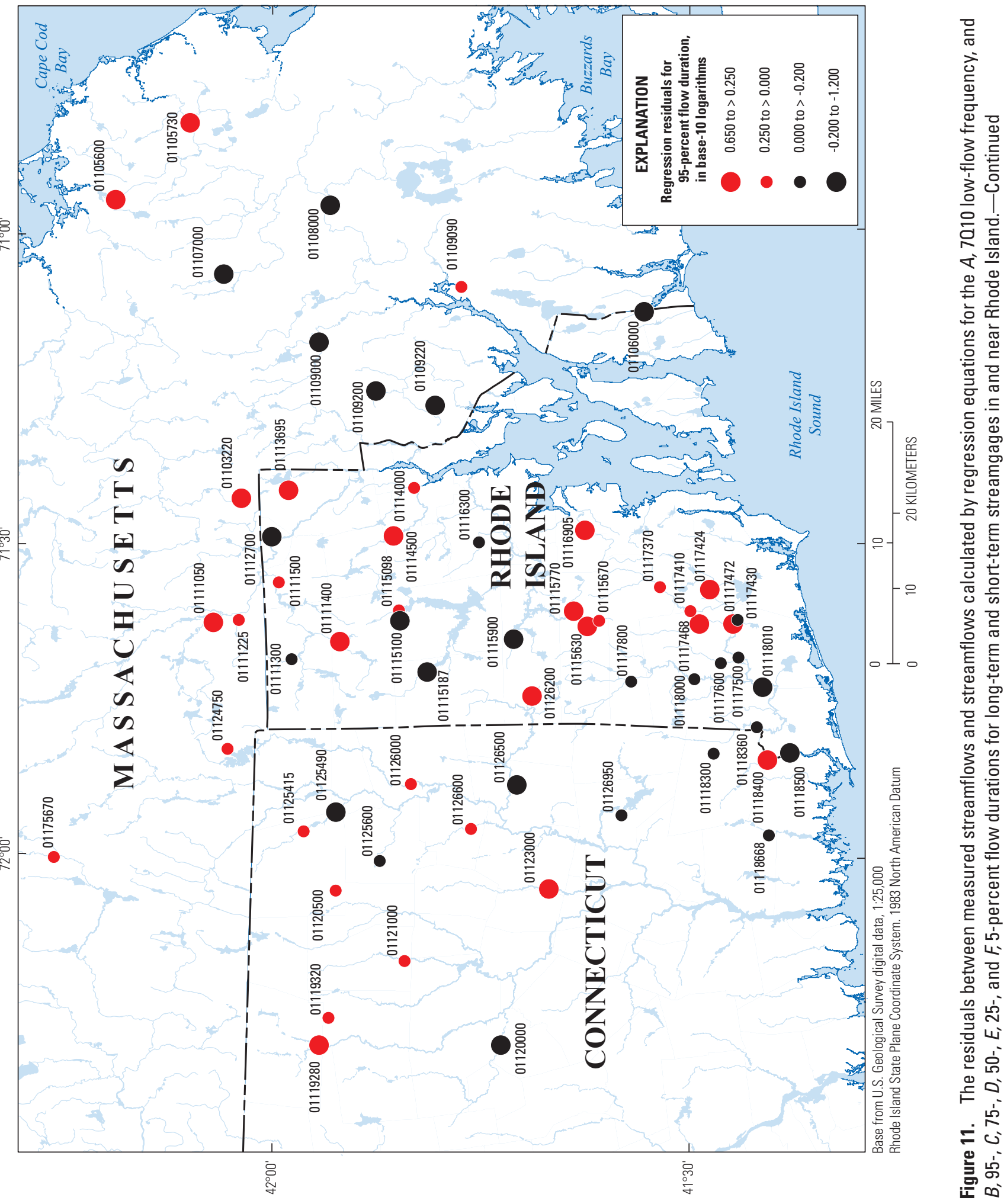




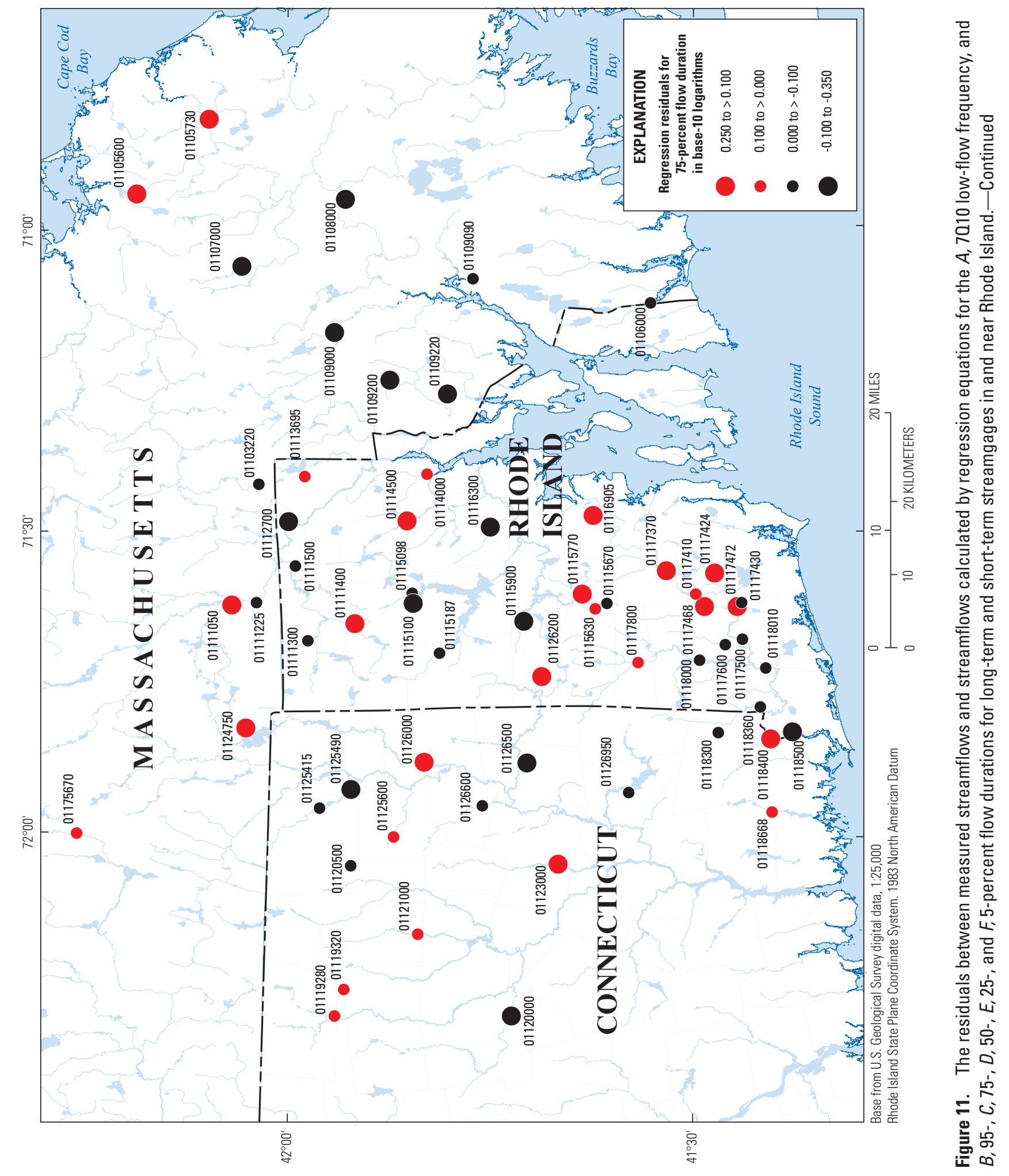




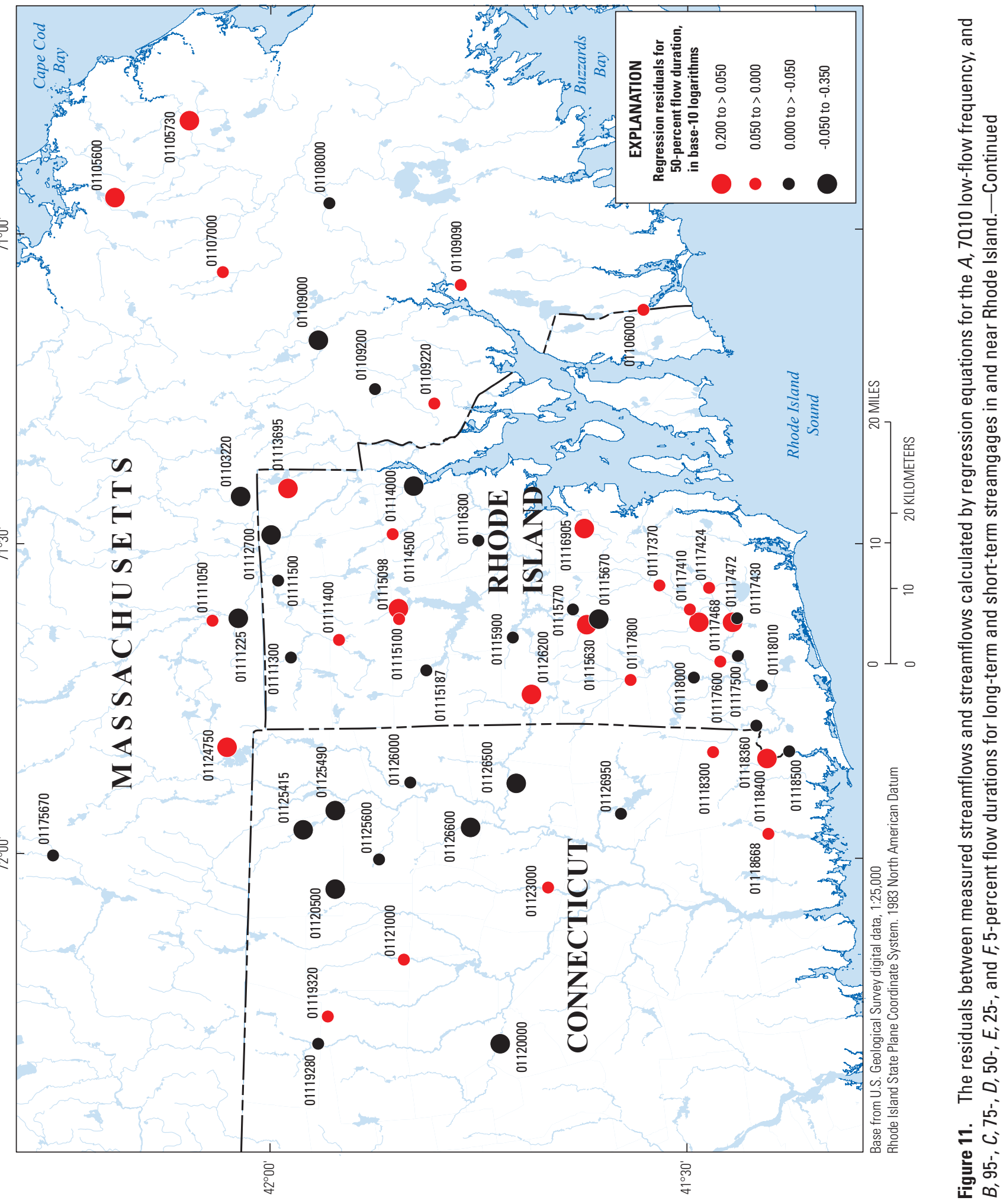




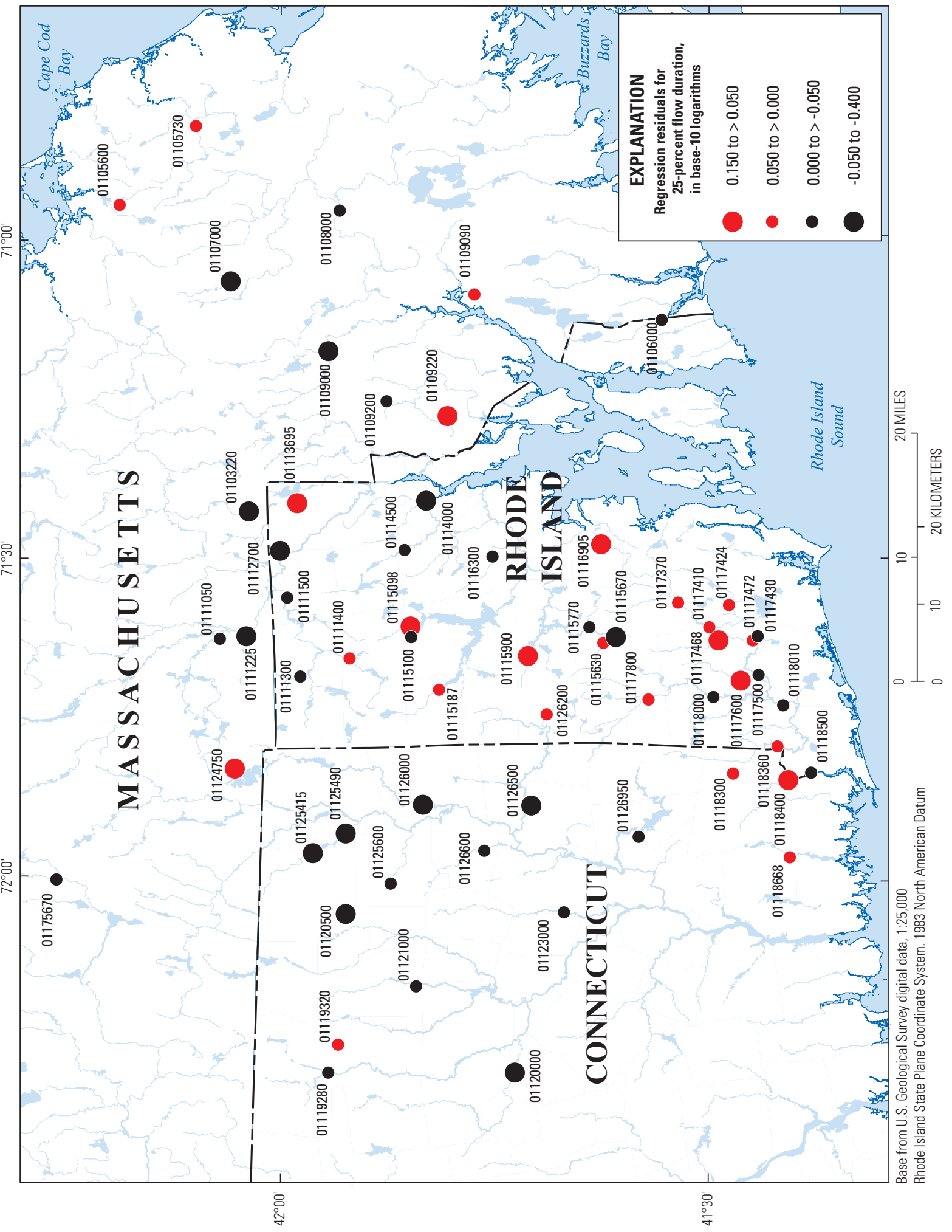

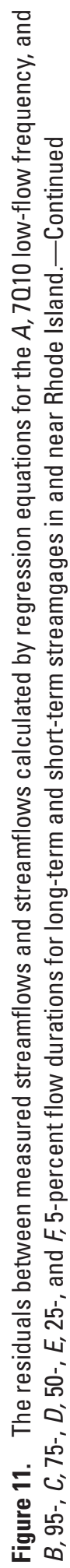




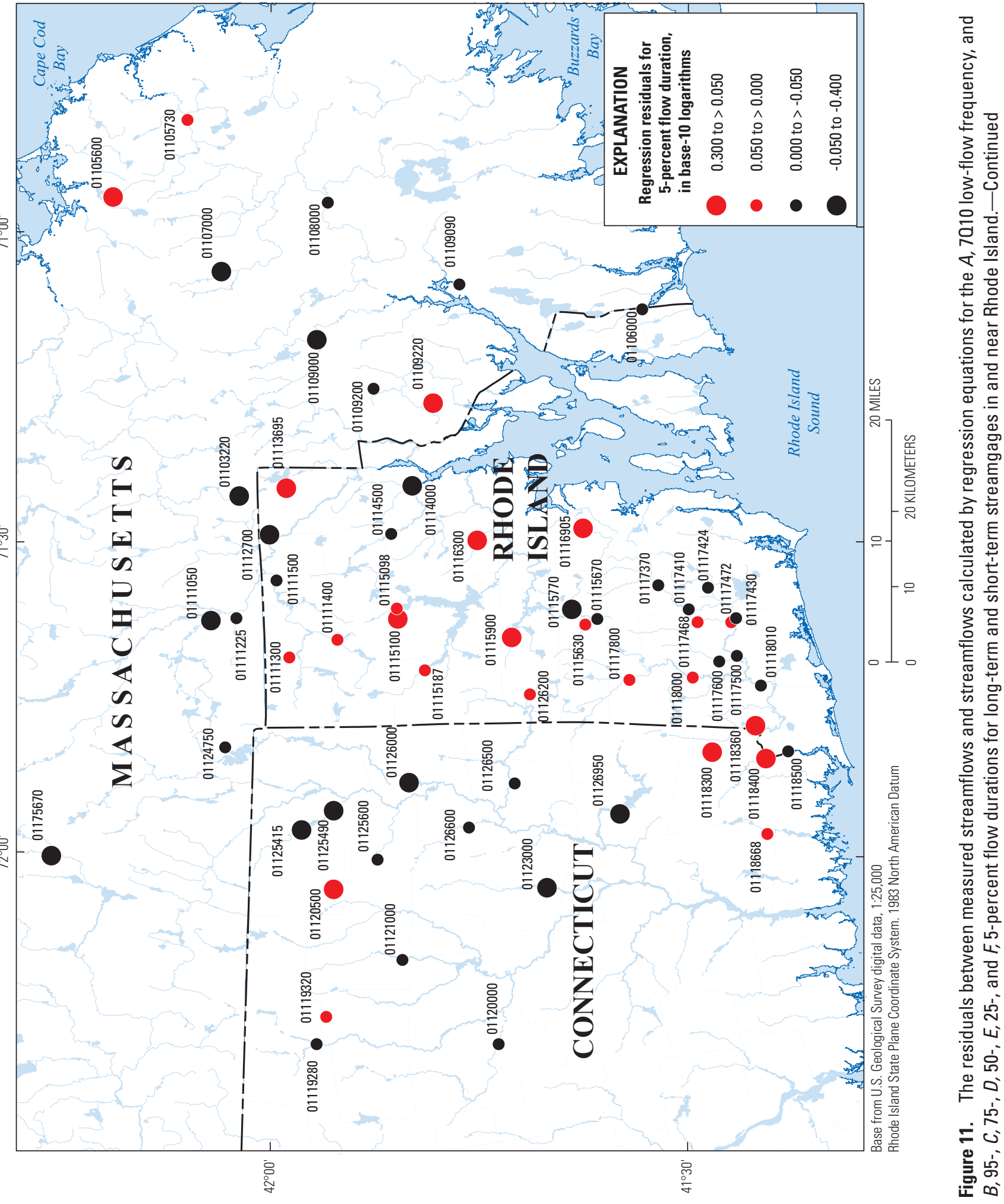


$\boldsymbol{A}$

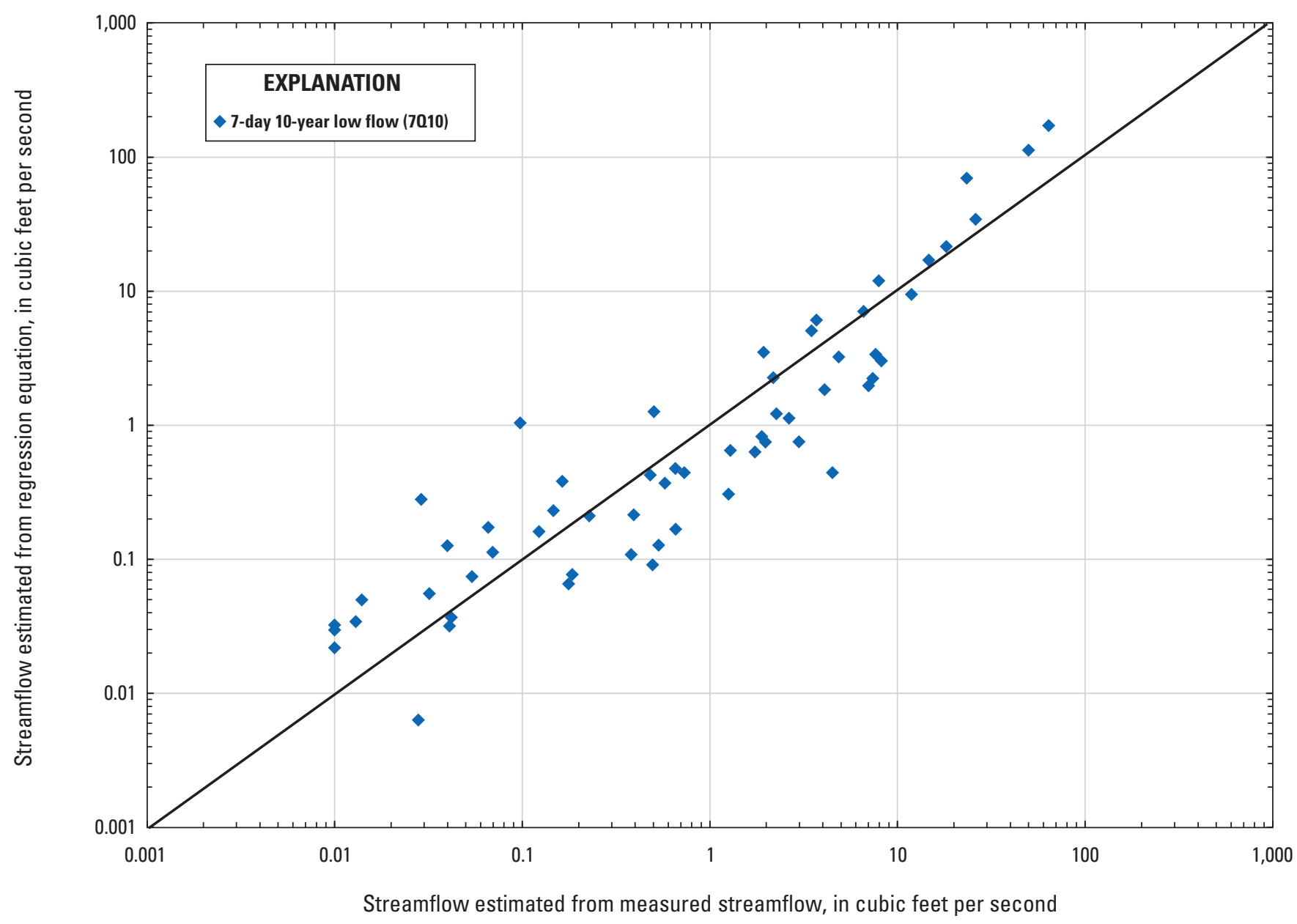

Figure 12. Comparisons of the $A, 7010$ low-flow frequency, and $B, 95-, C, 75-, D, 50-, E$, 25-, and $F$, 5-percent flow durations estimated from measured streamflow and regression equations for long-term and short-term streamgages in and near Rhode Island. 


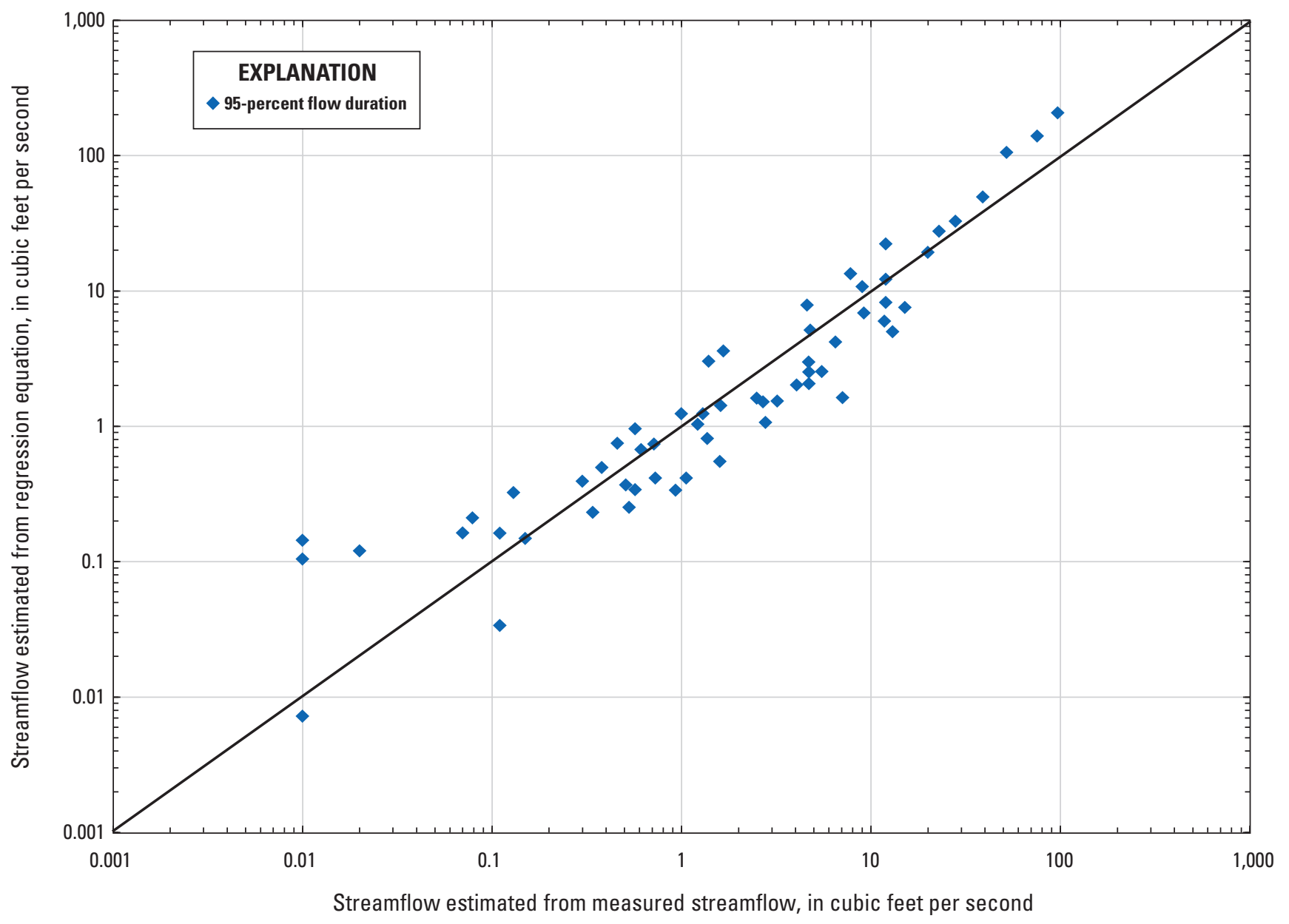

Figure 12. Comparisons of the $A, 7010$ low-flow frequency, and $B, 95-, C, 75-, D, 50-, E, 25-$, and $F, 5$-percent flow durations estimated from measured streamflow and regression equations for long-term and short-term streamgages in and near Rhode Island.-Continued 
C

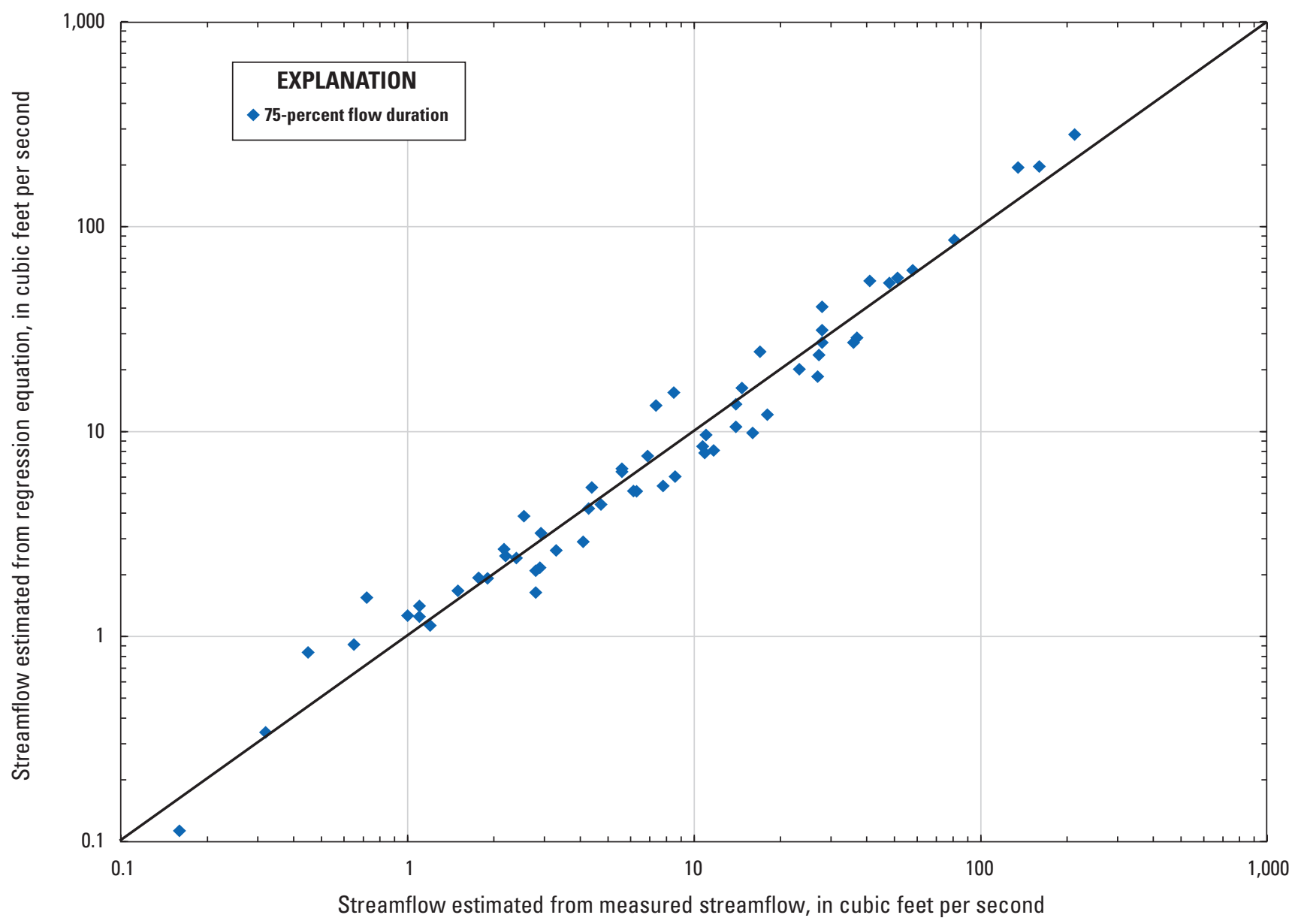

Figure 12. Comparisons of the $A, 7010$ low-flow frequency, and $B, 95-, C, 75-, D, 50-, E$, 25-, and $F, 5$-percent flow durations estimated from measured streamflow and regression equations for long-term and short-term streamgages in and near Rhode Island.-Continued 


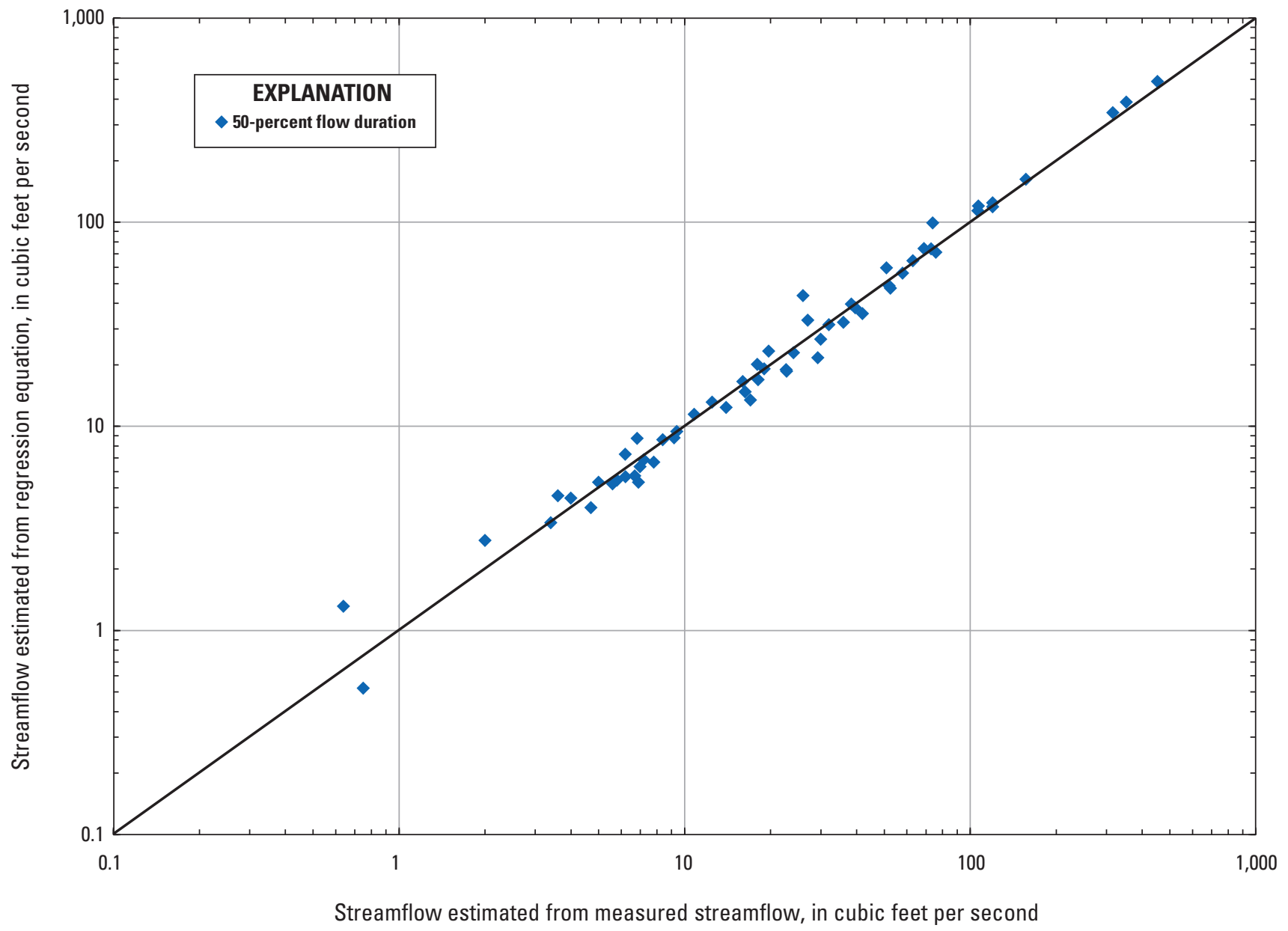

Figure 12. Comparisons of the $A, 7010$ low-flow frequency, and $B, 95-, C, 75-, D, 50-, E, 25-$, and $F, 5$-percent flow durations estimated from measured streamflow and regression equations for long-term and short-term streamgages in and near Rhode Island.-Continued 
$\boldsymbol{E}$

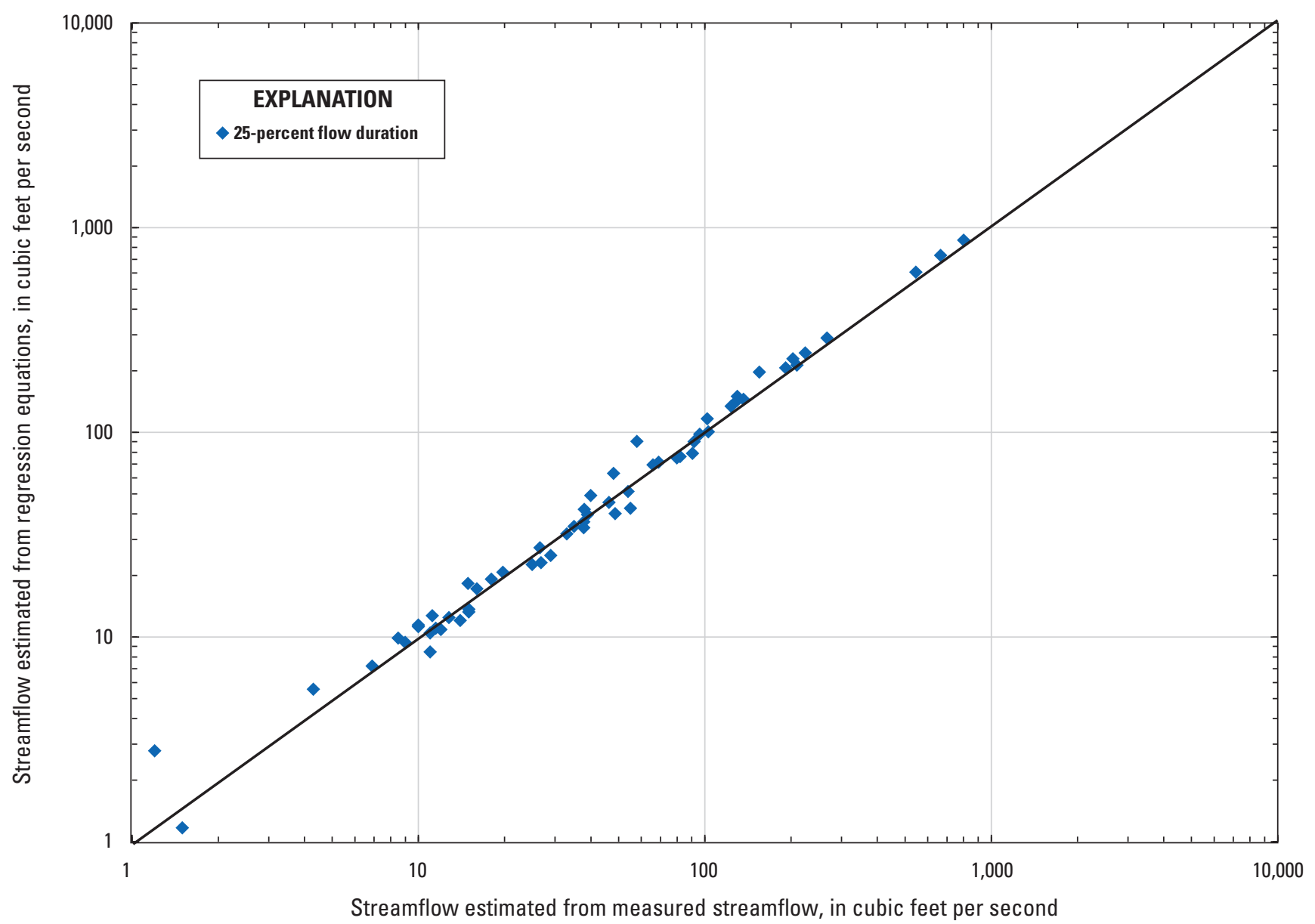

Figure 12. Comparisons of the $A, 7010$ low-flow frequency, and $B, 95-, C, 75-, D, 50-, E, 25$-, and $F, 5$-percent flow durations estimated from measured streamflow and regression equations for long-term and short-term streamgages in and near Rhode Island.-Continued 
$\boldsymbol{F}$

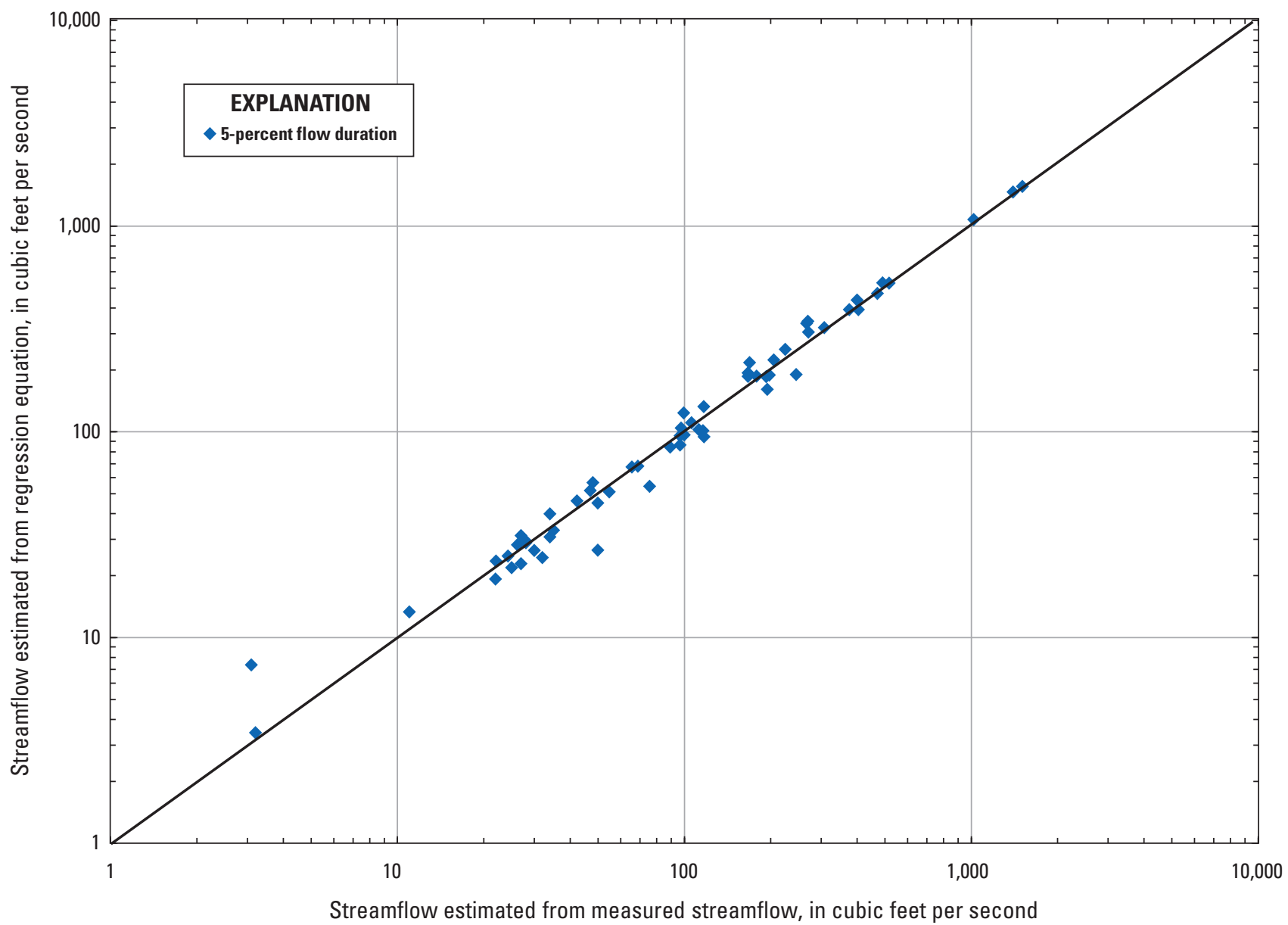

Figure 12. Comparisons of the $A, 7010$ low-flow frequency, and $B, 95-, C, 75-, D, 50-, E, 25-$, and $F$, 5-percent flow durations estimated from measured streamflow and regression equations for long-term and short-term streamgages in and near Rhode Island.-Continued 
75-, 50-, 25-, and 5-percent flow durations (figs. 12C-F), no clear bias of the streamflow values generated by regression equations with respect to measured streamflows is evident. Maps showing the residuals between measured streamflows and streamflows calculated by regression equations for the $A, 7 \mathrm{Q} 10$ low-flow frequency, and $B, 95-, C, 75-, D, 50-$, $E, 25-$, and $F, 5$-percent flow durations for long-term and short-term streamgages in and near Rhode Island.

\section{Prediction Intervals}

Prediction intervals indicate the uncertainty inherent in use of the equations. At the 90-percent confidence level, prediction intervals can be calculated for estimates obtained from the regression equations. The assurance is 90 percent that the true value of the streamflow statistic for an ungaged site will be within the prediction interval. The lower and upper boundaries of the 90 -percent prediction intervals can be computed by

$$
Q_{L P I}=\left(\frac{Q}{T}\right) \leq Q \leq(Q \times T)=Q_{U P I}
$$

where

$$
\begin{aligned}
& Q \quad \text { is the estimated streamflow statistic for the } \\
& \text { site, } \\
& Q_{L P I} \quad \text { is the estimated lower boundary of the } \\
& \text { 90-percent prediction interval, } \\
& Q_{U P I} \quad \text { is the estimated boundary of the upper } \\
& \text { 90-percent prediction interval, and } \\
& T \quad \text { is the 90-percent prediction interval } \\
& \text { determined from equation } 8 \text { below. }
\end{aligned}
$$

$$
T=10^{\left[t_{(\alpha \alpha 2, n-p)} \times S_{i}\right]}
$$

where

$t_{(\alpha / 2, n-p)} \quad$ is the critical value from the student's $t$ distribution,

$\alpha \quad$ is the alpha level ( $\alpha=0.10$ for 90 -percent prediction intervals),

$n-p \quad$ is the number of degrees of freedom with $n$ data values (for 60 streamgages) used in the regression analysis,

$p \quad$ is the number of parameters in the equation (equal to the number of explanatory variables or basin characteristics plus one), and

$S_{i} \quad$ is computed from equation 9 below.
Critical values from the student's $t$ distribution are listed in many introductory statistics textbooks.

The value of $S_{i}$ is computed using the equation

$$
S_{i}=\left[\gamma^{2}+\left(x_{i} \times U \times x_{i}^{\prime}\right)\right]^{0.5}
$$

where

$$
\begin{gathered}
\gamma^{2} \quad \begin{array}{c}
\text { is the model-error variance (equal to the root } \\
\text { mean square error (RMSE) squared), }
\end{array} \\
x_{i} \quad \begin{array}{c}
\text { is a row vector of the logarithms of the basin } \\
\text { characteristics for site } i \text { which has been }
\end{array} \\
\text { augmented by a } 1 \text { as the first element, } \\
U \quad \text { is the covariance matrix for the regression } \\
\text { coefficients, and } \\
x_{i}^{\prime} \quad \text { is the transpose of } x_{i} \text { (Ludwig and Tasker, } \\
\text { 1993). }
\end{gathered}
$$

The values of $t_{(\alpha 2, n-p)}$ and $U$ needed for equations 8 and 9 for the 21 regression equations are presented in table 12 . The values of $\gamma^{2}$ needed in equation 9 can be calculated by squaring the value of the user-weighted WLS-RMSE or the leftcensored regression-RMSE (base-10 logarithm) in table 12.

\section{Example Computations}

Two example computations of selected regression equations and the 90-percent prediction intervals of the estimates are provided. The first computation is provided for Dunderry Brook at Meetinghouse Lane at Little Compton, R.I. (01106110) (fig. 8 and table 4, in back of report). The values of the explanatory variables used in the regression equation for the 90-percent flow duration (table 11) were a drainage area (DRNAREA) of $1.26 \mathrm{mi}^{2}\left(x_{1}\right)$ and a stream density (STRDENED) of $2.96 \mathrm{mi} / \mathrm{mi}^{2}\left(x_{2}\right)$ (table 9). Substituting the values in the equation for the 90-percent flow duration produces

$Q_{90}=0.1995 \times\left(1.26 \mathrm{mi}^{2}\right)^{1.35} \times\left(2.96 \mathrm{mi} / \mathrm{mi}^{2}\right)^{-1.48}=0.055 \mathrm{ft}^{3} / \mathrm{s}$.

Calculation of the 90-percent prediction intervals use equations 7-9. The calculation starts with equation 9, then goes to equation 8 , and then equation 7 . Data needed for equations 8 and 9 are in table 12 .

For equation 9 the model error variance, $\gamma^{2}$, equals the user-weighted WLS-RMSE (base-10 logarithm) (table 12) squared, $\gamma^{2}=(0.2894)^{2}=0.0838$, and $U$ also comes from table 12 . 


$$
\begin{aligned}
& \begin{array}{l}
U=\left[\begin{array}{rrr}
0.225593836 & -0.070349579 & -0.395675480 \\
-0.070349579 & 0.05312461 & 0.021187091 \\
-0.395675480 & 0.021187091 & 1.175994738
\end{array}\right] \\
\begin{aligned}
x_{i} \times U \times x_{i}^{\prime}= & \left(\left((1 \times 0.225593836)+\left(\left(\log 10\left(1.26 \mathrm{mi}^{2}\right)\right) \times-0.070349579\right)+\left(\left(\log 10\left(2.96 \mathrm{mi} / \mathrm{mi}^{2}\right)\right)\right.\right.\right. \\
& \times-0.395675480)) \times 1)+\left(\left((1 \times-0.070349579)+\left(\left(\log 10\left(1.26 \mathrm{mi}^{2}\right)\right) \times 0.053112461\right)\right.\right. \\
& \left.\left.+\left(\left(\log 10\left(2.96 \mathrm{mi}^{2} / \mathrm{mi}^{2}\right)\right) \times 0.021187091\right)\right) \times\left(\log 10\left(1.26 \mathrm{mi}^{2}\right)\right)\right)+(((1 \times-0.395675480) \\
& \left.+\left(\left(\log 10\left(1.26 \mathrm{mi}^{2}\right)\right) \times 0.021187091\right)+\left(\left(\log 10\left(2.96 \mathrm{mi}^{2} / \mathrm{mi}^{2}\right)\right) \times 1.175994738\right)\right) \\
& \times\left(\left(\log 10\left(2.96 \mathrm{mi}^{2} / \mathrm{mi}^{2}\right)\right)\right.
\end{aligned} \\
\begin{aligned}
x_{i} \times U \times x_{i}^{\prime}= & (((0.2256)+(-0.0071)+(-0.1865)) \times 1)+(((-0.0703)+(0.0053)+(0.0010)) \times 0.1004) \\
& +(((-0.3957)+(0.0021)+(0.5542)) \times 0.4713))
\end{aligned} \\
x_{i} \times U \times x_{i}^{\prime}=(0.0320 \times 1)+(-0.0640 \times 0.1004)+(0.1606 \times 0.4713)
\end{array} \\
& x_{i} \times U \times x_{i}^{\prime}=(0.0320)+(-0.0064)+(0.0757)=0.1013
\end{aligned}
$$

For equation 8 , the value of $t$ from the student's $t$ distribution $=t_{(0.10 / 2,60-3)}=1.672($ table 12$)$.

$$
T=10^{\left[t_{(\propto / 2, n-p)} \times S_{i}\right]}=10^{[1.672 \times 0.4302]}=10^{[0.7193]}=5.2396
$$

For equation 7 ,

$Q_{L P I}=Q_{90} / T=0.055 / 5.2396=0.010 \mathrm{ft}^{3} / \mathrm{s}$

$Q_{U P I}=Q_{90} \times T=0.055 \times 5.2396=0.288 \mathrm{ft}^{3} / \mathrm{s}$

$Q_{L P I} \leq Q_{90} \leq Q_{U P I}=0.010 \mathrm{ft}^{3} / \mathrm{s} \leq 0.055 \mathrm{ft}^{3} / \mathrm{s} \leq 0.288 \mathrm{ft}^{3} / \mathrm{s}$.

The second example computation is provided for Fisherville Brook at Liberty Church Rd. near Exeter, R.I. (01117360) (fig. 8 and table 4, in back of report). The values of the explanatory variables used in the regression equation for the 7Q10 low-flow frequency (table 11) were a drainage area (DRNAREA) of $8.09 \mathrm{mi}^{2}\left(x_{1}\right)$ and a stream density (STRDENED) of $1.51 \mathrm{mi} / \mathrm{mi}^{2}\left(x_{2}\right)$ (table 9). Substituting the values in the equation for the $7 \mathrm{Q} 10$ low-flow frequency produces

$Q_{7 Q 10}=0.0311 \times\left(8.09 \mathrm{mi}^{2}\right)^{1.71} \times\left(1.51 \mathrm{mi} / \mathrm{mi}^{2}\right)^{-2.53}=0.391 \mathrm{ft}^{3} / \mathrm{s}$

The calculation starts with equation 9, then goes to equation 8 , and then equation 7. Data needed for equations 8 and 9 are in table 12.

For equation 9 the model error variance, $\gamma^{2}$, equals the left-censored regression-RMSE (base-10 logarithm) (table 12) squared, $\gamma^{2}=(0.4853)^{2}=0.2355$, and $U$ also comes from table 12 . 


$$
\begin{aligned}
& U=\left[\begin{array}{rrr}
0.225593836 & -0.070349579 & -0.395675480 \\
-0.070349579 & 0.053112461 & 0.021187091 \\
-0.395675480 & 0.021187091 & 1.175994738
\end{array}\right] \\
& x_{i} \times U \times x_{i}^{\prime}=\left(\left((1 \times 0.225593836)+\left(\left(\log 10\left(8.09 \mathrm{mi}^{2}\right)\right) \times-0.070349579\right)+\left(\left(\log 10\left(1.51 \mathrm{mi} / \mathrm{mi}^{2}\right)\right)\right.\right.\right. \\
& \times-0.395675480)) \times 1)+\left(\left((1 \times-0.070349579)+\left(\left(\log 10\left(8.09 \mathrm{mi}^{2}\right)\right) \times 0.053112461\right)\right.\right. \\
& \left.\left.+\left(\left(\log 10\left(1.51 \mathrm{mi} / \mathrm{mi}^{2}\right)\right) \times 0.021187091\right)\right) \times\left(\log 10\left(8.09 \mathrm{mi}^{2}\right)\right)\right)+(((1 \times-0.395675480) \\
& \left.+\left(\left(\log 10\left(8.09 \mathrm{mi}^{2}\right)\right) \times 0.021187091\right)+\left(\left(\log 10\left(1.51 \mathrm{mi} / \mathrm{mi}^{2}\right)\right) \times 1.175994738\right)\right) \\
& \times\left(\left(\log 10\left(1.51 \mathrm{mi} / \mathrm{mi}^{2}\right)\right)\right. \\
& x_{i} \times U \times x_{i}^{\prime}=(((0.2256)+(-0.0639)+(-0.0708)) \times 1)+(((-0.0703)+(0.0482)+(0.0038)) \times 0.9079) \\
& +(((-0.3957)+(0.0192)+(0.2105)) \times 0.1790)) \\
& x_{i} \times U \times x_{i}^{\prime}=(0.0909 \times 1)+(-0.0183 \times 0.9079)+(-0.1660 \times 0.1790) \\
& x_{i} \times U \times x_{i}^{\prime}=(0.0909)+(-0.0166)+(-0.0297)=0.0446 \\
& S_{i}=\left[\gamma^{2}+\left(x_{i} \times U \times x_{i}^{\prime}\right)\right]^{0.5}=[0.2355+0.0446]^{0.5}=[0.2801]^{0.5}=0.5292
\end{aligned}
$$

The value of $t$ from the student's $t$ distribution $=t_{(0.10 / 2,60-3)}=$ 1.672 (table 12).

$$
T=10^{\left[t_{\left.(\ltimes / 2, n-p) \times S_{i}\right]}\right.}=10^{[1.672 \times 0.5292]}=10^{[0.8848]}=7.6701
$$

For equation 7,

$Q_{L P I}=Q_{90} / T=0.391 / 7.6701=0.051 \mathrm{ft}^{3} / \mathrm{s}$

$Q_{U P I}=Q_{90} \times T=0.391 \times 7.6701=3.00 \mathrm{ft}^{3} / \mathrm{s}$

$Q_{L P I} \leq Q_{7 Q 10} \leq Q_{U P I}=0.051 \mathrm{ft}^{3} / \mathrm{s} \leq 0.391 \mathrm{ft}^{3} / \mathrm{s} \leq 3.00 \mathrm{ft}^{3} / \mathrm{s}$.

\section{Limitations of Regression Equations}

Use of the regression equations presented in this report in determining selected streamflow statistics is limited by the range of the basin-characteristics data used to develop the equations and by the accuracy of the estimates. These equations should not be used for the determination of streamflow statistics at ungaged sites for which the basin characteristics are outside the range of those used to develop the regression equations. The ranges of the basin-characteristics data used as explanatory variables to develop the flow-duration and low-flow-frequency regression equations are listed in table 13, and the corresponding accuracies of the estimates calculated by these equations are in table 11. The use of these regression equations requires that the physical and climatic basin characteristics be determined in a GIS based on the same datasets (table 13) that were used to develop the equations outlined in this report.
The equations, which are based on data from streams with little to no flow alteration, will give estimates only of the natural flows for a selected site. They will not give estimates of altered flow for sites where the flow is affected by structures and artificial processes such as dams, surfacewater withdrawals, groundwater withdrawals (pumping wells), diversions, and wastewater discharges. To apply the equations to streamflow data for such sites, the user should adjust the estimates for the alterations accordingly. The equations are not applicable in areas of Rhode Island where groundwater contributing areas and surface-water drainage areas to stream sites differ appreciably. In these areas, groundwater can flow from one surface-water drainage area into another; therefore, for basins whose groundwater contributing areas are larger than their surface-water drainage areas, the equations would likely underestimate streamflows. Conversely, for areas whose groundwater-contributing areas are smaller than their surface-water drainage areas, the equation would likely overestimate streamflows. Several areas in Rhode Island where groundwater contributing areas and surface-water drainage areas to stream sites differ appreciably include Queens Fort Brook in the Usquepaug-Queen River Basin (Allen and others, 1966; Dickerman and others, 1997; Barlow and Dickerman, 2001; Granato and others, 2003; Zarriello and Bent, 2004; and Bent and others, 2011), Mishnock River and Old Hickory Brook in the Big River Basin (Granato and others, 2003; and Granato and Barlow, 2005), several coastal rivers in the Hunt-Annaquatuck-Pettaquamscutt River Basin (Rosenshein and others, 1968; Barlow and Dickerman, 2001; 


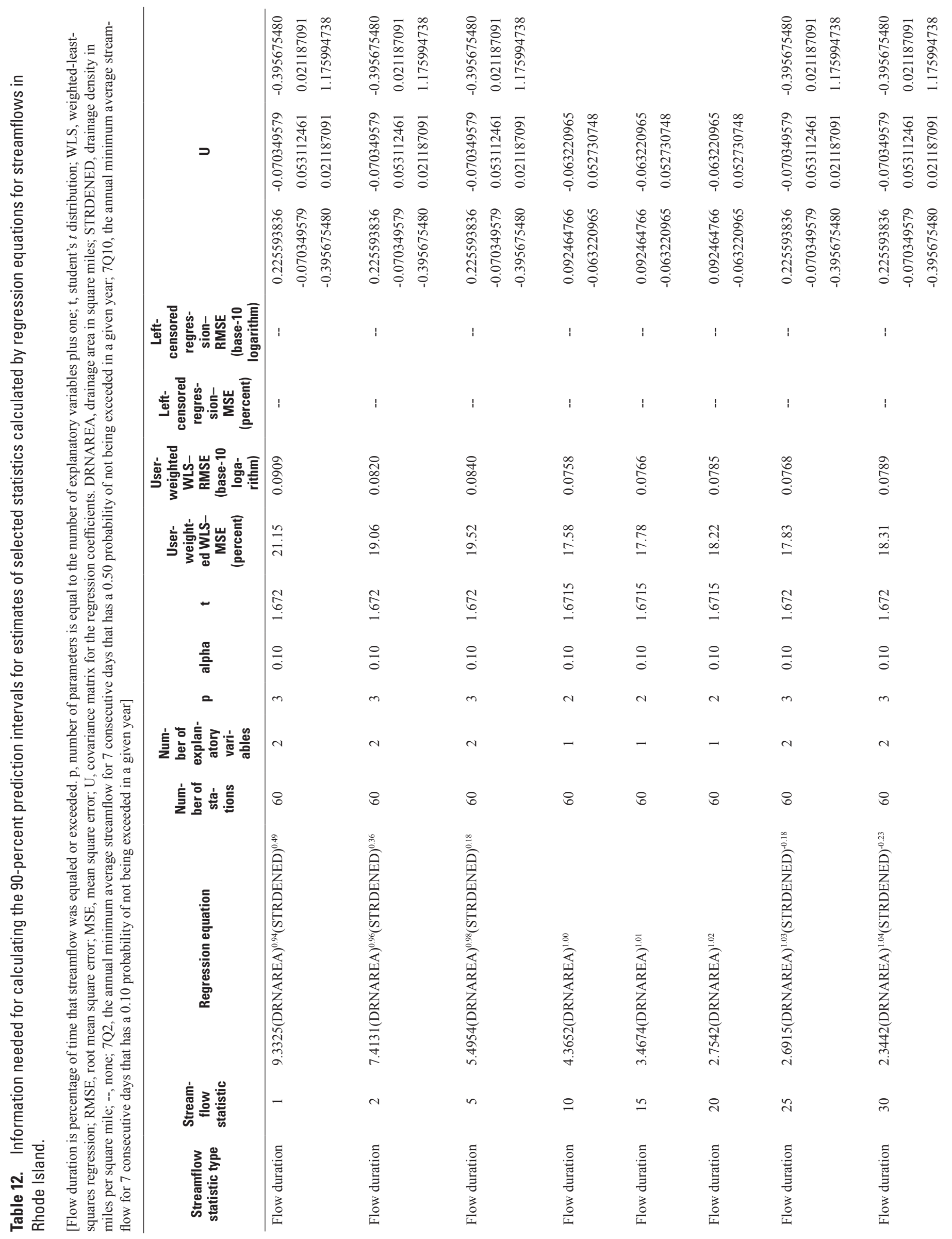


44 Equations for Estimating Selected Streamflow Statistics in Rhode Island

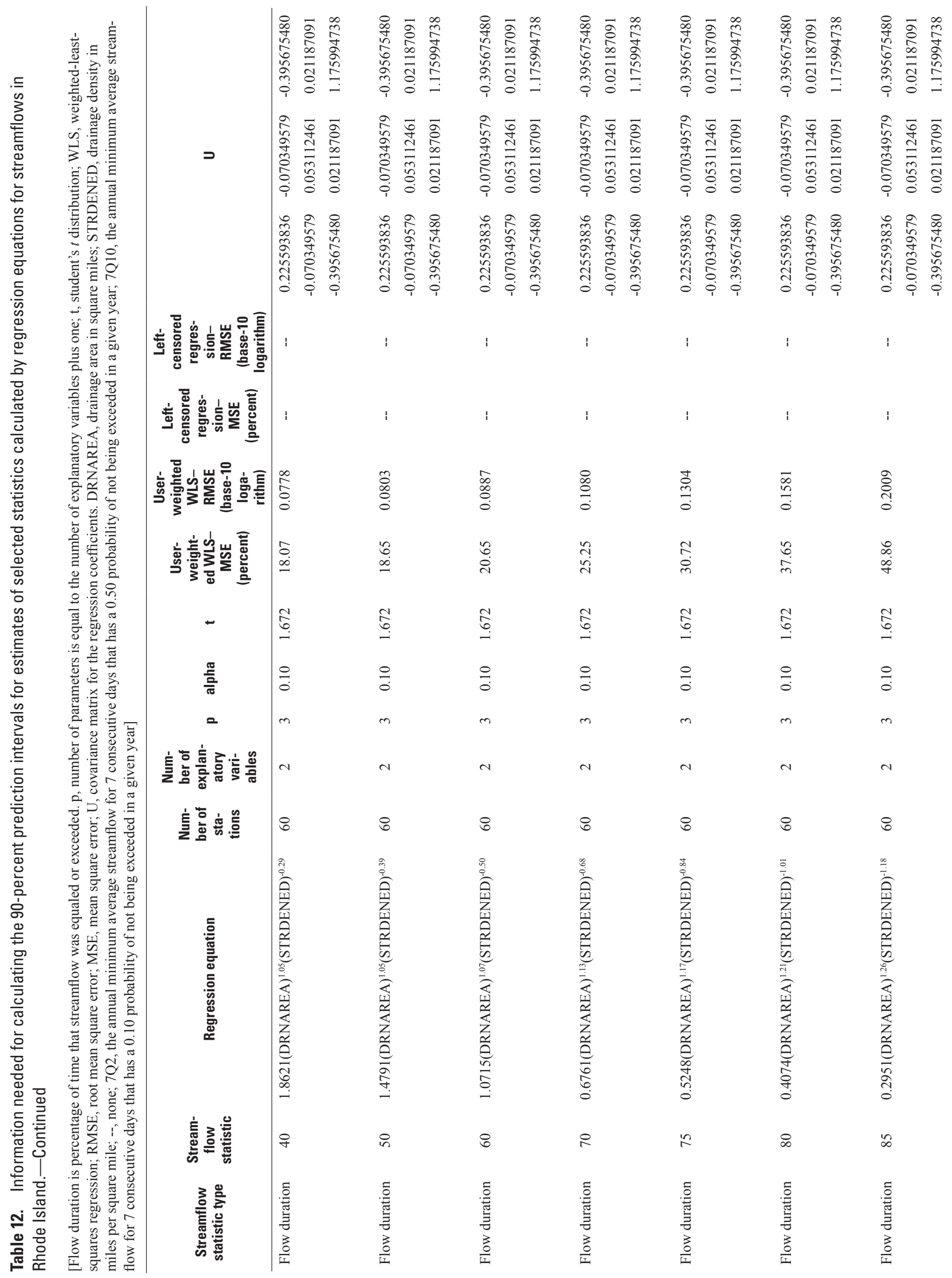




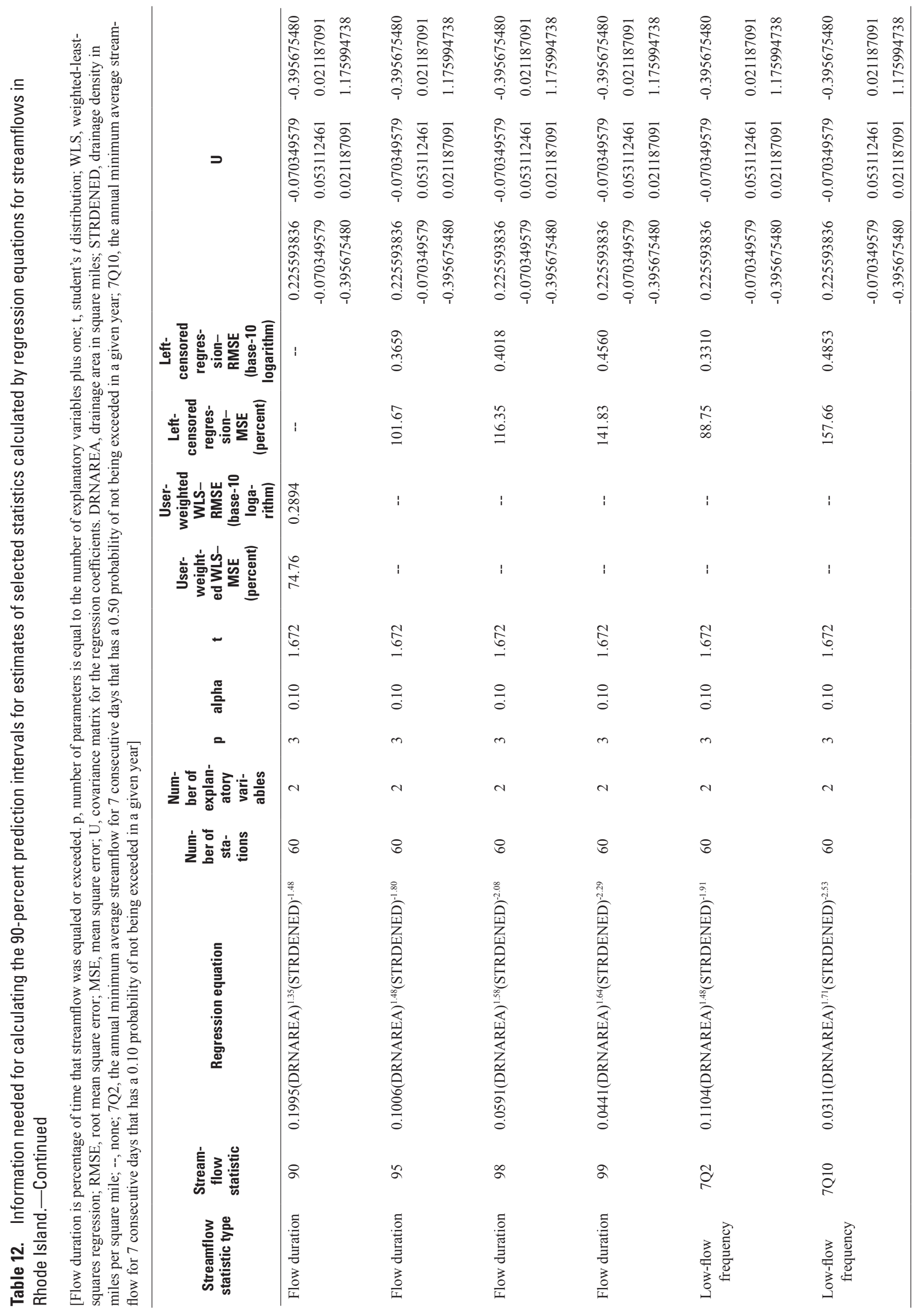


Table 13. Range of basin characteristics used as explanatory variables in the regression equations for estimating selected streamflow statistics in Rhode Island.

[DRNAREA, drainage area; STRDENED, drainage density; $\mathrm{mi}^{2}$, square miles; $\mathrm{mi} / \mathrm{mi}^{2}$, miles per square mile]

\begin{tabular}{lcc}
\hline \multicolumn{1}{c}{ Explanatory variable } & $\begin{array}{c}\text { Minimum } \\
\text { value }\end{array}$ & $\begin{array}{c}\text { Maximum } \\
\text { value }\end{array}$ \\
\hline Drainage area (DRNAREA) $\left(\mathrm{mi}^{2}\right)$ & 0.52 & 294 \\
Drainage density $(\mathrm{STRDENED})\left(\mathrm{mi} / \mathrm{mi}^{2}\right)$ & 0.94 & 3.49 \\
\hline
\end{tabular}

and Barlow and Ostiguy, 2007), and the South Coastal Basin (Friesz, 2004; Masterson and others, 2007; and Friesz, 2010). The regression equations are not applicable to other areas of Rhode Island having known appreciable differences between surface-water drainage areas and groundwater contributing areas. Additionally, the equation is not applicable to streams with losing reaches. Losing streams are defined as streams or stream reaches that lose water to the groundwater system (Winter and others, 1998, p. 9-10 and 16-17). Generally, a stream reach is losing where the groundwater table does not intersect the streambed in the channel (the water table is below the streambed) during low-flow periods. Losing stream reaches commonly begin where the stream flows from an area of the basin underlain by till or bedrock onto an area underlain by stratified deposits (where hillsides meet river valleys). At such junctures, a stream can lose a substantial amount of water through its streambed. The accuracies of the regression equations are functions of the quality of the data used in to develop the equations. These data include the streamflow data used to estimate the statistics, information about possible unknown flow alterations to the stream above a site, and the measured basin characteristics. Basin characteristics used in the development of the regression equations are limited by the accuracy of the digital data layers available and used at the time (2014) of this study. In the future, geospatial data layers of basin characteristics (table 7) likely will be more detailed and accurate and at higher resolution, for stream networks from the USGS NHD (http://nhd.usgs.gov/); elevation from USGS NED (http://ned.usgs.gov/); land cover, land use, and surficial geology from RIGIS (http://www.edc. uri.edu/rigis/default.html), MassGIS (http://www.mass.gov/ anf/research-and-tech/it-serv-and-support/application-serv/ office-of-geographic-information-massgis/), MAGIC (http:// magic.lib.uconn.edu/), and University of Connecticut CLEAR (http://clear.uconn.edu/projects/landscape/); soils from NRCS SSURGO (http://soils.usda.gov/survey/geography/ssurgo/); and climate from the PRISM Climate Group, Oregon State University (http://www.prism.oregonstate.edu/).

\section{StreamStats Application and Considerations for Additional Study}

The USGS National StreamStats Web-based application (at http://water.usgs.gov/osw/streamstats/; Ries, 2007, and Turnipseed and Ries, 2007) includes a map-based interface that allows a user to click on the centerline for any stream site, which causes the application to calculate selected streamflow statistics and the 90-percent prediction intervals from the equations for that ungaged stream site. The application also provides the user with the basin-characteristic values that were used to calculate the regression equations. The regression equations' basin-characteristic values for a user-selected stream site are determined by the use of digital map data from ArcGIS (geographic information system software from the Environmental Systems Research Institute, Inc. (Esri) (http://www.esri.com/)). The output includes a map of the drainage-basin boundary determined for the stream site, the values of the GIS-measured basin characteristics, the estimated streamflow statistics, and prediction intervals for the estimates. The user can also click on streamgage and partialrecord station symbols and be provided selected streamflow statistics and basin characteristics from a database for that site.

As considerations for additional study, the 21 selected regression equations for streamflow statistics (table 11), as well as the 90-percent prediction intervals, could be incorporated into the USGS National StreamStats Web-based application. The at-site estimates of the selected streamflow statistics at the long- and short-term streamgages and partial-record stations could also be put into the StreamStats database for retrieval. Another consideration is that new basin characteristics that were not available for this study could be tested as potential explanatory variables. These digital data layers likely would improve the accuracy of the measured basin characteristics used as explanatory variables to estimate selected streamflow statistics in Rhode Island but only after re-examination of the regression equations.

\section{Summary and Conclusions}

The equations for estimating selected streamflow statistics may be used by Federal, State, and local water managers in addressing numerous water issues. This report documents the development of regression equations by the U.S. Geological Survey (USGS), in cooperation with the Rhode Island Water Resources Board, that can be used statewide for determining selected statistics for streamflows unaffected by alterations at ungaged sites in Rhode Island. Multiple and simple linear regression equations were developed to estimate the 99-, 98-, 95-, 90-, 85-, 80-, 75-, 70-, 60-, 50-, 40-, 30-, 25-, 20-, 15-, 10-, 5-, 2-, and 1-percent flow durations and the frequency statistics 7Q2 (7-day, 2-year) and 7Q10 (7-day, 10-year). An additional 49 selected statistics also were estimated for longand short-term streamgages and partial-record stations for flow 
durations between the 99.99 and 0.01 percent, and the mean annual, mean monthly, and median monthly streamflows. Data also are provided to allow the user to calculate the 90-percent prediction intervals for the 21 streamflow statistics.

A total of 70 selected streamflow statistics were determined for 41 long-term streamgages (with 8 or more water and climatic years of record), 21 short-term streamgages (with 1 to 7 water and climatic years of record), and 135 partialrecord stations (with more than 11 miscellaneous streamflow measurements) in Rhode Island, eastern Connecticut, and southeastern and south-central Massachusetts. Estimates of the long-term streamflow statistics for 21 short-term streamgages and 135 partial-record stations were developed by using the Maintenance of Variance Extension, type 1 (MOVE.1), technique. This technique involved fitting the MOVE.1 equation for daily mean streamflows at short-term streamgages and miscellaneous streamflow measurements at partial-record stations to concurrent daily mean streamflows at the 16 index streamgages. In general, the index streamgage which provided the relation with the highest Pearson's correlation coefficient $(r)$ and the most linear plot of the data was selected.

The regression analyses for developing equations to estimate selected streamflow statistics related the 19 flowduration and 2 low-flow frequency statistics to 31 different drainage-basin characteristics (physical, land-cover, and climatic characteristics) for 41 long-term and 19 of 21 shortterm streamgages (60 total streamgages) in Rhode Island and nearby in Connecticut and Massachusetts. Two of the 21 short-term streamgages were excluded from the regression analyses because the period of record for another streamgage nearby on the same river was longer; this longer record was used in the analyses. In addition, the drainage areas and basin characteristics of the two streamgages were similar. Use of the streamflow records, drainage areas, and basin characteristics for both sites would have produced redundant data points in the regression analyses. The 135 partial-record stations were not used in the regression analyses.

A user-weighted least-squares (WLS) regression technique in the weighted-multiple-linear regression (WREG) program was used in the regression analyses for the 90 - to 1-percent flow durations. Left-censored regression analyses were used to account for zero flows at the 99- and 98-percent and 7Q10 flow durations (for four streamgages) and at the 95-percent and 7Q2 flow durations (for two streamgages). Coefficients of determination $\left(R^{2}\right)$ are not determined when the user-WLS regression technique is used in WREG or in the left-censored regression analyses.

The regression analyses determined that the basin characteristics drainage area (DRNAREA) and stream density (total length of streams divided by the drainage area) (STRDENED) were the only significant explanatory variables for 16 of the 19 flow-duration and the 2 low-flow-frequency regression equations. For the other three flow-duration (10-, 15-, and 20 -percent) equations, drainage area was the only significant explanatory variable.
The standard error of the estimate for the 21 regression equations ranged from 17.58 to 141.83 percent. The low-flow statistics for the 99- to 85-percent flow durations and 7Q2 and $7 \mathrm{Q} 10$ had the highest standard errors of the estimate, ranging from 48.68 to 141.83 percent. The standard error of the estimate for the medium- to high-flow statistics - the 80- to 1-percent flow durations - ranged from 17.58 to 37.65 percent, with the standard errors for the 60- to 1-percent flow durations all being less than about 21 percent.

The equations, which are based on data from streams with little to no flow alteration, will give an estimate of only the natural flows at a selected site. They will not give an estimate of altered flows at a site where the streamflow is affected by structures and artificial processes such as dams, surfacewater withdrawals, groundwater withdrawals (pumping wells), diversions, and wastewater discharges. If the equations are used to estimate statistics for sites where streamflow has been altered, the user should adjust the estimates accordingly. The regression equations should be used only for ungaged sites with drainage areas between 0.52 and 294 square miles $\left(\mathrm{mi}^{2}\right)$ and stream densities between 0.94 and 3.49 miles per square miles $\left(\mathrm{mi} / \mathrm{mi}^{2}\right)$. The equations are not applicable (1) for Block Island because there are no streams on the island, (2) in areas where groundwater-contributing areas and surface-water drainage areas to stream sites differ appreciably, and (3) for losing stream reaches where the stream may flow from of a till and bedrock hillside into a sand and gravel river valley.

As considerations for additional study, the 21 regression equations developed for this study, as well as the 90-percent prediction intervals of the estimate, could be added to the USGS National StreamStats Web-based application (http://water.usgs.gov/osw/streamstats/). The 21 selected streamflow statistics, plus the additional statistics: 24 flow durations between the 99.99 and 0.01 percent, mean annual flow, and 12 mean and median monthly flows estimated for the long- and short-term streamgages and partial-record stations also could be incorporated into the StreamStats database.

\section{References Cited}

Ahearn, E.A., 2008, Flow durations, low-flow frequencies, and monthly median flows for selected streams in Connecticut through 2005: U.S. Geological Survey Scientific Investigations Report 2007-5270, 33 p., http://pubs.usgs. gov/sir/2007/5270/.

Ahearn, E.A., 2010, Regional regression equations to estimate flow-duration statistics at ungaged stream sites in Connecticut: U.S. Geological Survey Scientific Investigations Report 2010-5052, 45 p., http://pubs.usgs.gov/sir/2010/5052/.

Ahearn, E.A., Ries, K.G., III, and Steeves, P.A., 2006, Streamstats: U.S. Geological Survey Web Application for Streamflow Statistics for Connecticut: U.S. Geological Survey Fact Sheet 2006-3129, 4 p., http://pubs.usgs.gov/fs/2006/3129/. 
Allen, W.B., Hahn, G.W., and Brackley, R.A., 1966, Availability of ground water upper Pawcatuck River Basin Rhode Island: U.S. Geological Survey Water-Supply Paper 1821, 66 p., 3 pls.

Archfield, S.A., Vogel, R.M., Steeves, P.A., Brandt, S.L., Weiskel, P.K., and Garabedian, S.P., 2010, The Massachusetts Sustainable-Yield Estimator-A decisionsupport tool to assess water availability at ungaged stream locations in Massachusetts: U.S. Geological Survey Scientific Investigations Report 2009-5227, 41 p., plus CD-ROM, http://pubs.usgs.gov/sir/2009/5227/.

Armstrong, D.S., Parker, G.W., and Richards, T.A., 2008, Characteristics and classification of least altered streamflows in Massachusetts: U.S. Geological Survey Scientific Investigations Report 2007-5291, 113 p., plus CD-ROM, http://pubs.usgs.gov/sir/2007/5291/.

Barlow, P.M., and Dickerman, D.C., 2001, Numerical-simulation and conjunctive-management models of the HuntAnnaquatucket-Pettaquamscutt stream-aquifer system, Rhode Island: U.S. Geological Survey Professional Paper 1636, 88 p., http://pubs.usgs.gov/pp/pp1636.

Barlow, P.M., and Ostiguy, L.J., 2007, Simulation of hydrologic-system responses to ground-water withdrawals in the Hunt-Annaquatucket-Pettaquamscutt stream-aquifer system, Rhode Island: U.S. Geological Survey Open-File Report 2006-1226, 51 p., http://pubs.usgs.gov/of/2006/1226/.

Bent, G.C., and Archfield, S.A., 2002, A logistic regression equation for estimating the probability of a stream flowing perennially in Massachusetts: U.S. Geological Survey Water-Resources Investigations Report 02-4043, 45 p., http://pubs.usgs.gov/wri/wri024043.

Bent, G.C., and Steeves, P.A., 2006, A revised logistic regression equation and an automated procedure for mapping the probability of a stream flowing perennially in Massachusetts: U.S. Geological Survey Scientific Investigations Report 2006-5031, 107 p., http://pubs.usgs.gov/ $\operatorname{sir} / 2006 / 5031 /$.

Bent, G.C., Zarriello, P.J., Granato, G.E., Masterson, J.P., Walter, D.A., Waite, A.M., and Church, P.E., 2011, Simulated effects of water withdrawals and land-use changes on streamflows and groundwater levels in the Pawcatuck River Basin, southwestern Rhode Island and southeastern Connecticut: U.S. Geological Survey Scientific Investigations Report 2009-5127, 254 p., http://pubs.usgs.gov/ $\operatorname{sir} / 2009 / 5127 /$.

Bisese, J.A., 1995, Methods for estimating the magnitude and frequency of peak discharges of rural, unregulated streams in Virginia: U.S. Geological Survey Water-Resources Investigations Report 94-4148, 70 p., 1 pl., http://pubs.usgs.gov/ wri/wri944148.
Cervione, M.A., Jr., Richardson, A.R., and Weiss, L.A., 1993, Low-flow characteristics of selected streams in Rhode Island: U.S. Geological Survey Water-Resources Investigations Report 93-4046, 16 p., http://pubs.er.usgs.gov/ publication/wri934046.

Choquette, A.F., 1988, Regionalization of peak discharges for streams in Kentucky: U.S. Geological Survey WaterResources Investigations Report 87-4209, 105 p., 1 pl.

Cohn, T.A., 1988, Adjusted maximum likelihood estimation of the moments of lognormal populations from type I censored data: U.S. Geological Survey Open-File Report 88-350, 34 p., http://pubs.er.usgs.gov/publication/ofr88350.

Denny, C.S., 1982, Geomorphology of New England: U.S. Geological Survey Professional Paper 1208, 18 p., 1 pl., http://pubs.er.usgs.gov/publication/pp1208.

DeSimone, L.E., and Ostiguy, L.J., 1999, A vulnerability assessment of public-supply wells in Rhode Island: U.S. Geological Survey Water-Resources Investigations Report 99-4160, 153 p., http://pubs.er.usgs.gov/publication/ wri994160.

Dickerman, D.C., Kliever, J.D., and Stone, J.R., 1997, Hydrogeology, water quality, and simulation of ground-waterdevelopment alternatives in the Usquepaug-Queen groundwater reservoir, southern Rhode Island: U.S. Geological Survey Water-Resources Investigations Report 97-4126, 48 p., http://pubs.er.usgs.gov/publication/wri974126.

Eash, D.A., and Barnes, K.K., 2012, Methods for estimating low-flow frequency statistics and harmonic mean flows for streams in Iowa: U.S. Geological Survey Scientific Investigations Report 2012-5171, 99 p., http://pubs.usgs.gov/ $\operatorname{sir} / 2012 / 5171 /$.

Efroymson, M.A., 1960, Multiple regression analysis, in Ralston, A., and Wilf, H.S., eds., Mathematical methods for digital computers: New York, John Wiley and Sons, Inc., p. 191-203.

Eng, Ken, Chen, Yin-Yu, and Kiang, J.E., 2009, User's guide to the weighted-multiple-linear regression program (WREG version 1.0): U.S. Geological Survey Techniques and Methods, book 4, chap. A8, 21 p., http://pubs.usgs.gov/tm/tm4a8.

Fennessey, Neil, and Vogel, R.M., 1990, Regional flow-duration curves for ungauged sites in Massachusetts: Journal of Water-Resources Planning and Management, v. 116, no. 4, p. 530-549.

Flynn, K.M., Hummel, P.R., Lumb, A.M., and Kittle, J.L., Jr., 1995, User's manual for ANNIE, version 2, a computer program for interactive hydrologic data management: U.S. Geological Survey Water-Resources Investigations Report 95-4085, 211 p., http://pubs.er.usgs.gov/publication/ wri954085. 
Flynn, R.H., 2003a, Development of regression equations to estimate flow durations and low-frequency statistics in New Hampshire streams: U.S. Geological Survey WaterResources Investigations Report 02-4298, 66 p., http://pubs. usgs.gov/wri/wri02-4298/.

Flynn, R.H., 2003b, A stream-gaging network analysis for the 7-day, 10-year annual low flow in New Hampshire Streams: U.S. Geological Survey Water-Resources Investigations Report 03-4023, 31 p., http://pubs.usgs.gov/wri/wrir034023/.

Friesz, P.J., 2004, Delineation of areas contributing recharge to selected public-supply wells in glacial valley-fill and wetland settings, Rhode Island: U.S. Geological Survey Scientific Investigations Report 2004-5070, 57 p., http://pubs.usgs.gov/sir/2004/5070/.

Friesz, P.J., 2010, Delineation and prediction uncertainty of areas contributing recharge to selected well fields in wetland and coastal settings, southern Rhode Island: U.S. Geological Survey Scientific Investigations Report 2010-5060, 69 p., http://pubs.usgs.gov/sir/2010/5060/.

Granato, G.E., 2009, Computer programs for obtaining and analyzing daily mean streamflow data from the U.S. Geological Survey National Water Information System Web Site: U.S. Geological Survey Open-File Report 2008-1362, 123 p., on CD-ROM. (Also available at http://pubs.usgs. gov/of/2008/1362/).

Granato, G.E., and Barlow, P.M., 2005, Effects of alternative instream-flow criteria and water-supply demands on ground-water development options in the Big River Area, Rhode Island: U.S. Geological Survey Scientific Investigations Report 2004-5301, 110 p., http://pubs.usgs.gov/ sir/2004/5301/.

Granato, G.E., Barlow, P.M., and Dickerman, D.C., 2003, Hydrogeology and simulated effects of ground-water withdrawals in the Big River area, Rhode Island: U.S. Geological Survey Water-Resources Investigations Report 03-4222, 76 p., http://pubs.usgs.gov/wri/wri034222/.

Haecker, Stefan, 2000, The influence of land use upon ground water quality as reflected in the baseflow water quality of streams and rivers in Rhode Island: Kingston, Rhode Island, University of Rhode Island, Master's Thesis, Department of Civil Engineering, 261 p.

Helsel, D.R., 2005, Nondetects and data analysis-Statistics for censored environmental data: John Wiley and Sons, New Jersey, p. 250.

Hirsch, R.M., 1982, A comparison of four streamflow record extension techniques: Water Resources Research, v. 18, no. 4, p. 1081-1088.
Hortness, J.E., 2006, Estimating low-flow frequency statistics for unregulated streams in Idaho: U.S. Geological Survey Scientific Investigations Report 2006-5035, 31 p., http://pubs.usgs.gov/sir/2006/5035/.

Kliever, J.D, 1996, Low-flow characteristics of selected streams in northern Rhode Island: U.S. Geological Survey Water-Resources Investigations Report 95-4299, 11 p., http://pubs.er.usgs.gov/publication/wri954299.

Koltun, G.F., and Roberts, J.W., 1990, Techniques for estimating flood-peak discharges of rural, unregulated stream in Ohio: U.S. Geological Survey Water-Resources Investigations Report 89-4126, 68 p., 1 pl., http://pubs.er.usgs.gov/ publication/wri894126.

Koltun, G.F., and Schwartz, R.R., 1987, Multiple-regression equations for estimating low flows at ungaged stream sites in Ohio: U.S. Geological Survey Water-Resources Investigations Report 86-4354, 39 p., 6 pls., http://pubs.er.usgs. gov/publication/wri864354.

Koltun, G.F., and Whitehead, M.T., 2002, Techniques for estimating selected streamflow characteristics of rural unregulated streams in Ohio: U.S. Geological Survey WaterResources Investigations Report 02-4068, 50 p., http:// oh.water.usgs.gov/reports/Abstracts/wrir02-4068.html.

Kroll, C.N., and Stedinger, J.R., 1999, Development of regional regression relationships with censored data: Water Resources Research, v. 35, no. 3, p. 775-784.

Lorenz, D.L., and others, 2011, USGS library for S-PLUS for windows, release 4.0: U.S. Geological Survey Open-File Report 2011-1130, http://water.usgs.gov/software/S-PLUS/.

Ludwig, A.H., and Tasker, G.D., 1993, Regionalization of low-flow characteristics of Arkansas streams: U.S. Geological Survey Water-Resources Investigations Report 93-4013, 32 p., http://pubs.er.usgs.gov/publication/wri934013.

Lumb, A.M., Kittle, J.L., Jr., and Flynn, K.M., 1990, Users manual for ANNIE, a computer program for interactive hydrologic analyses and data management: U.S. Geological Survey Water-Resources Investigations Report 89-4080, 236 p., http://pubs.er.usgs.gov/publication/wri894080.

Lumia, Richard, 1991, Regionalization of flood discharges for rural, unregulated streams in New York, excluding Long Island: U.S. Geological Survey Water-Resources Investigations Report 90-4197, 119 p., 2 pls., http://ny.water.usgs. gov/pubs/wri/wri904197/.

Martin, G.R., and Arihood, L.D., 2010, Methods for estimating selected low-flow frequency statistics for unregulated streams in Kentucky: U.S. Geological Survey Scientific Investigations Report 2010-5217, 83 p., http://pubs.usgs. gov/sir/2010/5217/. 
Massachusetts Office of Geographic Information, 2007a: Massachusetts Office of Geographic Information, Impervious surface, accessed October 1, 2007, at http://www.mass. gov/anf/research-and-tech/it-serv-and-support/applicationserv/office-of-geographic-information-massgis/datalayers/ impervioussurface.html.

Massachusetts Office of Geographic Information, 2007b, Surficial geology 1:24,000: Massachusetts Office of Geographic Information, accessed October, 1, 2007, at http://www.mass.gov/anf/research-and-tech/it-serv-andsupport/application-serv/office-of-geographic-informationmassgis/datalayers/sg24k.html.

Massachusetts Office of Geographic Information, 2009, Land use (2005): Massachusetts Office of Geographic Information, accessed August 23, 2009, at http://www.mass.gov/ anf/research-and-tech/it-serv-and-support/application-serv/ office-of-geographic-information-massgis/datalayers/ lus2005.html.

Masterson, J.P., Sorenson, J.R., Stone, J.R., Moran, S.B., and Hougham, Andrea, 2007, Hydrogeology and simulated ground-water flow in the Salt Pond region of southern Rhode Island: U.S. Geological Survey Scientific Investigations Report 2006-5271, 56 p., http://pubs.usgs.gov/ $\operatorname{sir} / 2006 / 5271 /$.

Minitab, Inc., 2003, Meet Minitab—Release 14 for Windows: Minitab, Inc., 138 p.

National Oceanic and Atmospheric Administration, 2002, Monthly station normals of temperature, precipitation, and heating and cooling degree days - 1971-2000 - 37 Rhode Island: Asheville, N.C., National Oceanic and Atmospheric Administration, National Environmental Satellite, Data, and Information Service, and National Climatic Data Center, Climatography of the United States no. 81, 9 p., accessed March 3, 2012, at http://cdo.ncdc.noaa.gov/climatenormals/ clim81/RInorm.pdf.

Natural Resources Conservation Service, 2007, Soil survey geographic database: Natural Resources Conservation Service, accessed June 8, 2007, at http://soils.usda.gov/survey/ geography/ssurgo/.

PRISM Climate Group, 2007, Parameter-elevation regressions on independent slopes model climate mapping system: PRISM Climate Group, accessed June 8, 2007, at http://www.prism.oregonstate.edu/.

Rhode Island Department of Environmental Management, Office of Water Resources, 2005, Modified aquatic base flow (RI-ABF) for Rhode Island: Rhode Island Department of Environmental Management, 33 p., accessed March 3, 2012, at http://www.dem.ri.gov/programs/benviron/water/ withdraw/pdf/riabf.pdf.
Rhode Island Department of Environmental Management, Office of Water Resources, 2010, Draft streamflow depletion methodology: Rhode Island Department of Environmental Management, 42 p., accessed March 3, 2012, at http://www.watershedcounts.org/documents/ StreamFlowDepletionMethodology.pdf.

Rhode Island Department of Environmental Management and Rhode Island Water Resources Board Streamflow Committee, 2004, Recommendation for a stream gaging network in Rhode Island: Rhode Island Department of Environmental Management and Rhode Island Water Resources Board Streamflow Committee, 10 p., accessed March 3, 2012, at http://www.wrb.ri.gov/wapacfiles/streamgaging.pdf.

Rhode Island Geographic Information System, 2007, Glacial deposits: Rhode Island Geographic Information System, accessed June 8, 2007, at http://www.edc.uri.edu/rigis/data/ data.aspx? $\mathrm{ISO}=$ geoscientificInformation.

Rhode Island Geographic Information System, 2008a, Impervious surfaces [2003-04]: Rhode Island Geographic Information System, accessed February 10, 2008, at http:// www.edc.uri.edu/rigis/data/data.aspx?ISO=environment.

Rhode Island Geographic Information System, 2008b, Land use-2003/2004: Rhode Island Geographic Information System, accessed February 10, 2008, at http://www.edc.uri.edu/ rigis/data/data.aspx?ISO=environment.

Rhode Island Statewide Planning Program, 2000, Rhode Island land use trends and analyses (including land use surveys from the period 1970-95): Rhode Island Statewide Planning Program, Technical paper no. 149, p. 67, accessed March 3, 2012, at http://www.planning.ri.gov/documents/tp/ TP\%20149.PDF.

Rhode Island Water Allocation Program Advisory Committee, 2004, Streamflow subcommittee final report: Rhode Island Water Allocation Program Advisory Committee, 29 p., accessed March 3, 2012, at http://www.wrb.ri.gov/ wapacfiles/sffinalrpt.pdf.

Ries, K.G., III, 1990, Estimating surface-water runoff to Narragansett Bay, Rhode Island and Massachusetts: U.S. Geological Survey Water-Resources Investigations Report 89-4164, 44 p., 1 pl., scale 1:125,000, http://pubs.er.usgs. gov/publication/wri894164.

Ries, K.G., III, 1994a, Development and application of generalized least-squares regression models to estimate lowflow duration discharges in Massachusetts: U.S. Geological Survey Water-Resources Investigations Report 94-4155, 33 p., http://pubs.er.usgs.gov/publication/wri944155.

Ries, K.G., III, 1994b, Estimation of low-flow duration discharges in Massachusetts: U.S. Geological Survey Water-Supply Paper 2418, 50 p., http://pubs.er.usgs.gov/ publication/wsp2418. 
Ries, K.G., III, 1997, August median streamflows in Massachusetts: U.S. Geological Survey Water-Resources Investigations Report 97-4190, 27 p., http://pubs.er.usgs.gov/ publication/wri974190.

Ries, K.G., III, 1999, Streamflow measurements, basin characteristics, and streamflow statistics for low-flow partial-record stations operated in Massachusetts from 1989 through 1996: U.S. Geological Survey Water-Resources Investigations Report 99-4006, 162 p., http://pubs.er.usgs. gov/publication/wri994006.

Ries, K.G., III, 2007, The national streamflow statistics program: A computer program for estimating streamflow statistics for ungaged sites: U.S. Geological Survey Techniques and Methods 4-A6, 37 p., http://pubs.usgs.gov/tm/2006/ tm4a6/.

Ries, K.G., III, and Friesz, P.J., 2000, Methods for estimating low-flow statistics for Massachusetts streams: U.S. Geological Water-Resources Investigations Report 00-4135, 81 p., http://pubs.usgs.gov/wri/wri004135/.

Ries, K.J., III, Steeves, P.A., Freeman, Aleda, and Singh, Raj, 2000, Obtaining streamflow statistics for Massachusetts streams on the World Wide Web: U.S. Geological Survey Fact Sheet FS-104-00, 4 p., http://pubs.er.usgs.gov/ publication/fs 10400 .

Riggs, H.C., 1972, Low-flow investigations: U.S. Geological Survey Techniques of Water-Resources Investigations, book 4, chap. B1, 18 p., http://pubs.er.usgs.gov/publication/ twri04B1.

Risley, J.C., 1994, Estimating the magnitude and frequency of low flows of streams in Massachusetts: U.S. Geological Survey Water-Resources Investigations Report 94-4100, 29 p., http://pubs.er.usgs.gov/publication/wri944100.

Rosenshein, J.S., Gonthier, J.B., and Allen, W.B., 1968, Hydrologic characteristics and sustained yield of principle ground-water units Potowomut-Wickford area: U.S. Geological Survey Water-Supply Paper 1775, 38 p., 5 pls., http://pubs.usgs.gov/wsp/1775/.

Searcy, J.K., 1959, Flow-duration curves, in Manual of hydrology-Part 2. Low-flow techniques: U.S. Geological Survey Water-Supply Paper 1542-A, p. 1-33, http://pubs.er.usgs. gov/publication/wsp1542A.

Stuckey, M.H., 2006, Low-flow, base-flow, and mean-flow regression equations for Pennsylvania streams: U.S. Geological Survey Scientific Investigations Report 2006-5130, 84 p., http://pubs.usgs.gov/sir/2006/5130/.

Tasker, G.D., 1989, Regionalization of low flow characteristics using logistic and GLS regression, in Kavvas, M.L., ed., New directions for surface water modeling: IAHS Publication 181, p. 323-331.
The Nature Conservancy, 2007, Indicators of hydrologic alteration, user's manual, version 7: The Nature Conservancy, 70 p., accessed March 3, 2012, at http://www.nature. org/initiatives/freshwater/conservationtools/art17004.html.

TIBCO Software, Inc., 2008, TIBCO Spotfire S-Plus 8.1 for windows-User's guide: TIBCO Software Inc., 572 p.

Trench, E.C.T., 1991, Ground-water resources of Rhode Island: U.S. Geological Survey Open-File Report 91-199, 169 p., http://pubs.er.usgs.gov/publication/ofr91199.

Turnipseed, D.P., and Ries, K.G., III, 2007, The national streamflow statistics program: estimating high and low streamflow statistics for ungaged sites: U.S. Geological Survey Fact Sheet 2007-3010, 4 p., http://pubs.usgs.gov/ fs/2007/3010/.

University of Connecticut Center for Land Use Education and Research, 2007a, Connecticut land cover [2002]: University of Connecticut Center for Land Use Education and Research, accessed May 23, 2007, at http://clear.uconn.edu/ data/index.htm.

University of Connecticut Center for Land Use Education and Research, 2007b, Estimation tool for impervious surfaces: University of Connecticut Center for Land Use Education and Research, accessed May 23, 2007, at http://clear.uconn. edu/data/index.htm.

University of Connecticut Map and Geographic Information Center, 2007, Connecticut surficial materials: University of Connecticut Map and Geographic Information Center, accessed May 23, 2007, at http://magic.lib.uconn.edu/connecticut_data.html\#environmental.

U.S. Environmental Protection Agency, 1986, Technical guidance manual for performing wasteload allocations, Book VI, Design conditions - Chapter 1, Stream design flow for steady-state modeling: U.S. Environmental Protection Agency, EPA 440/4/86-014, 62 p., accessed August 12, 2012, at http://water.epa.gov/scitech/datait/models/dflow/ upload/wlabook6chapter1.pdf.

U.S. Environmental Protection Agency, 2006, Level III ecoregions: U.S. Environmental Protection Agency, accessed March 3, 2012, at http:/www.epa.gov/wed/pages/ ecoregions/level_iii.htm.

U.S. Fish and Wildlife Service, 1981, Interim regional policy for New England streamflow recommendations: Newton Corner, Mass., U.S. Fish and Wildlife Service, 3 p., accessed March 3, 2012, at http://www.fws.gov/ newengland/pdfs/Flowpolicy.pdf.

U.S. Geological Survey, 2007a, National Hydrography Dataset: U.S. Geological Survey, accessed June 8, 2007, at http://nhd.usgs.gov/index.html. 
U.S. Geological Survey, 2007b, National Elevation Dataset:

U.S. Geological Survey, accessed June 8, 2007, at

http://ned.usgs.gov/.

Veeger, A.I., and Johnston, H.E., 1996, Hydrogeology and water resources of Block Island, Rhode Island: U.S.

Geological Survey Water-Resources Investigations Report

94-4096, p. 76, http://pubs.er.usgs.gov/publication/

wri944096.

Vogel, R.M., and Kroll, C.N.,1990, Generalized low-flowfrequency relationships for ungaged sites in Massachusetts: Water-Resources Bulletin, v. 26, no. 2, p. 241-253.

Walker, P.N., and Lautzenheiser, Robert, 1991, Rhode Island floods and droughts, in National Water Summary 198889-Hydrologic events and floods and droughts: U.S. Geological Survey Water-Supply Paper 2375, p. 483-488, http://md.water.usgs.gov/publications/wsp-2375/ ri/index.html.

Wandle, S.W., Jr., and Randall, A.D., 1994, Effects of surficial geology, lakes and swamps, and annual water availability on low flows of streams in central New England, and their use in low-flow estimation: U.S. Geological Survey Water-Resources Investigations Report 93-4092, 57 p., http://pubs.er.usgs.gov/publication/wri934092.

Weibull, W., 1939, The phenomenon of rupture in solids: Stockholm, Ingeniors Vetenskaps Akademien Handlinga 153, p. 17.

Winter, T.C., Harvey, J.W., Franke, O.L., and Alley, W.M., 1998, Ground water and surface water - a single resource: U.S. Geological Survey Circular 1139, 79 p., http://pubs.usgs.gov/circ/circ1139/.

Zarriello, P.J., and Bent, G.C., 2004, A precipitation-runoff model for the analysis of the effects of water withdrawals and land-use change on streamflow in the UsquepaugQueen River Basin, Rhode Island: U.S. Geological Survey Scientific Investigations Report 2004-5139, 75 p., http://pubs.usgs.gov/sir/2004/5139/.

Zarriello, P.Z., Ahearn, E.A., and Levin, S.B., 2012, Magnitude of flood flows for selected annual exceedance probabilities in Rhode Island through 2010: U.S. Geological Survey Scientific Investigations Report 2012-5109, 81 p., http://pubs.usgs.gov/sir/2012/5109/. 
Tables 4, 5 


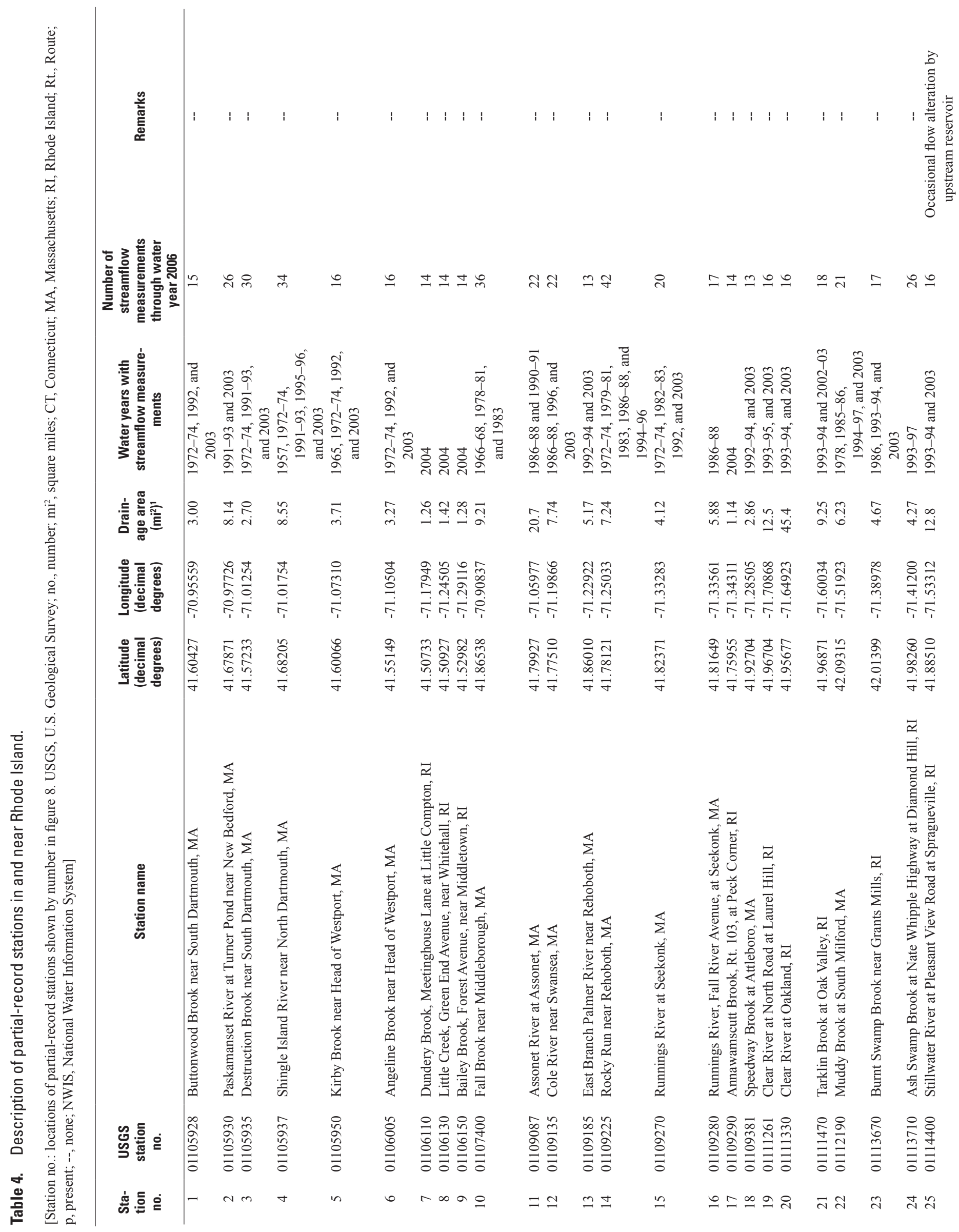




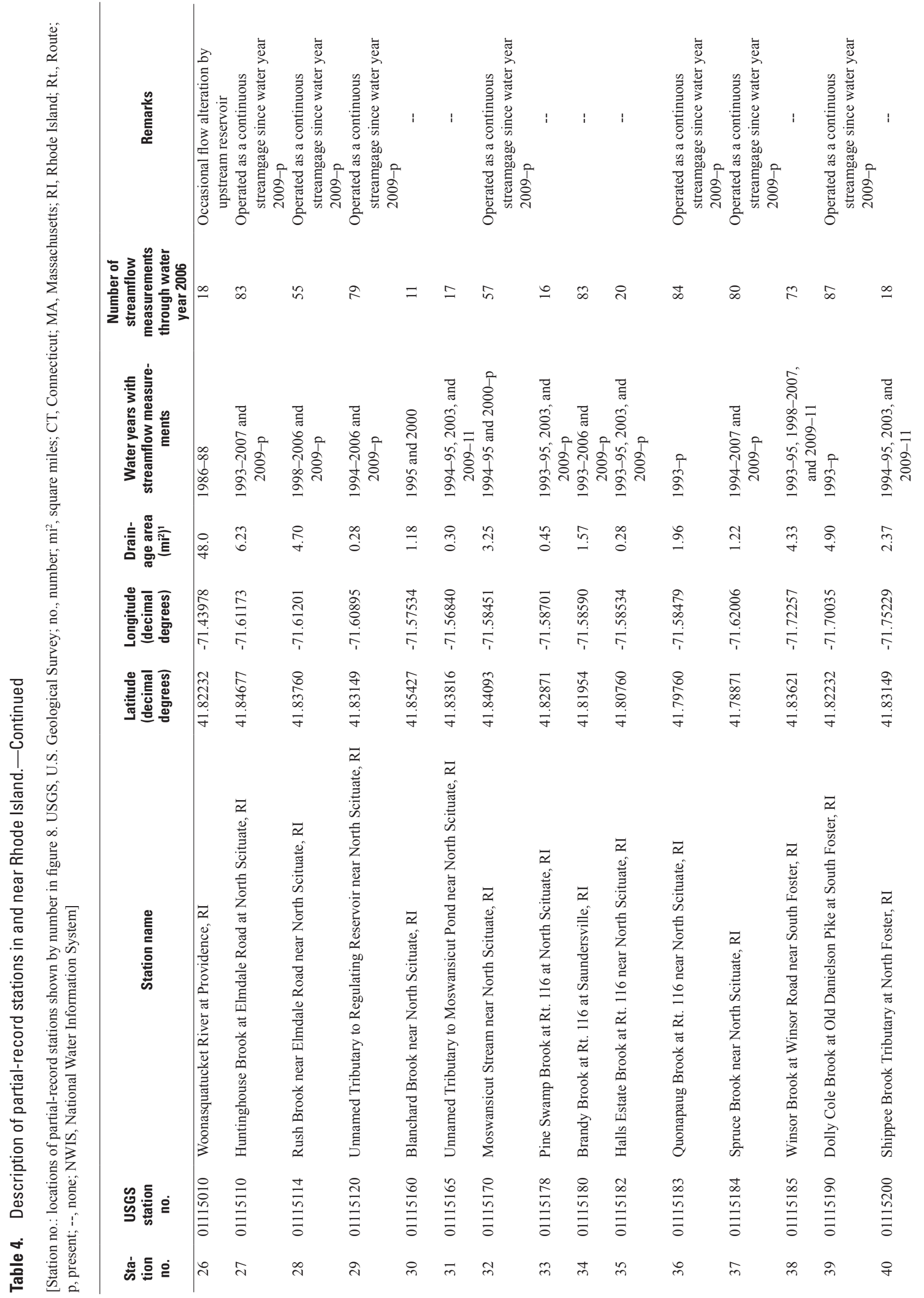




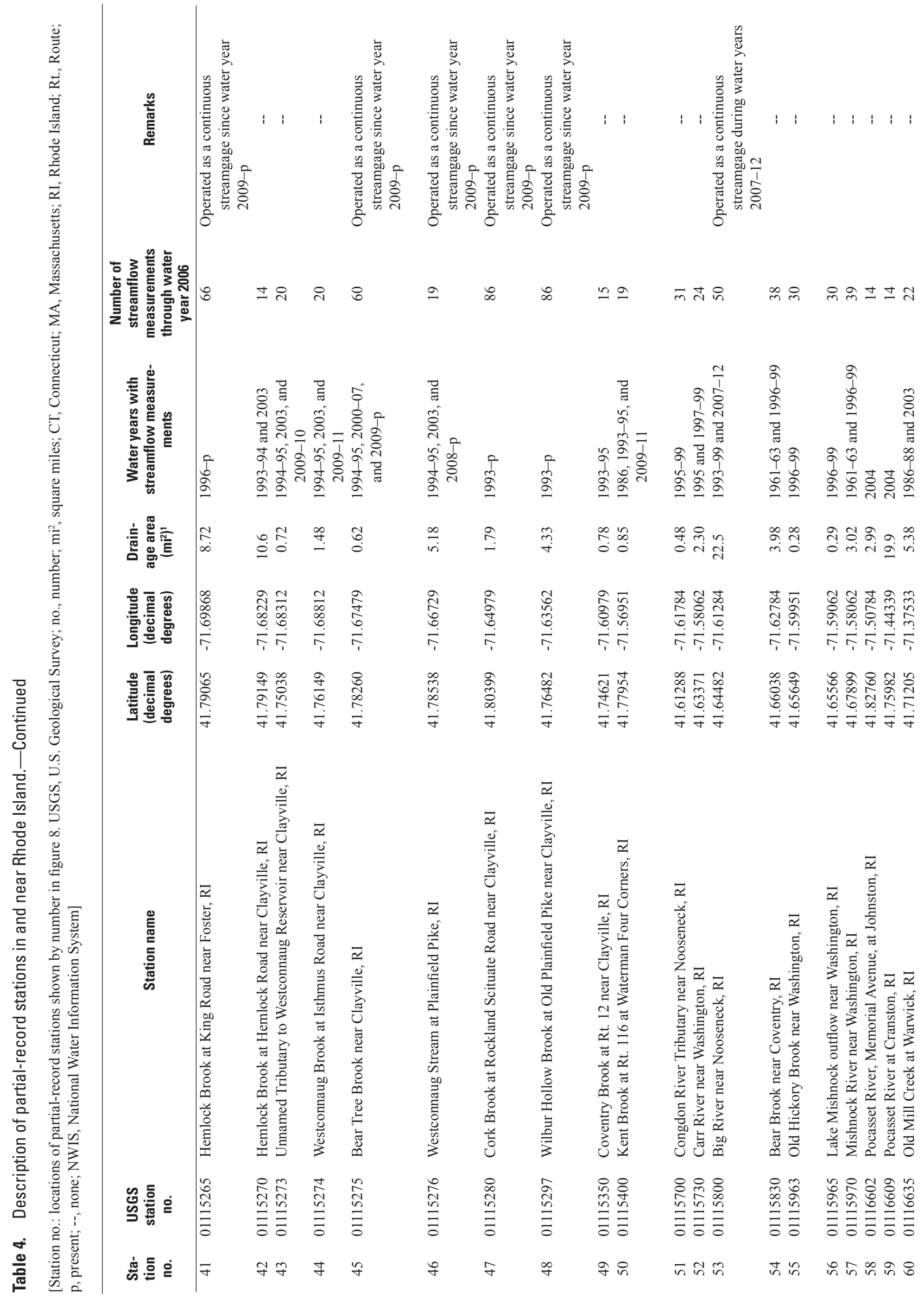




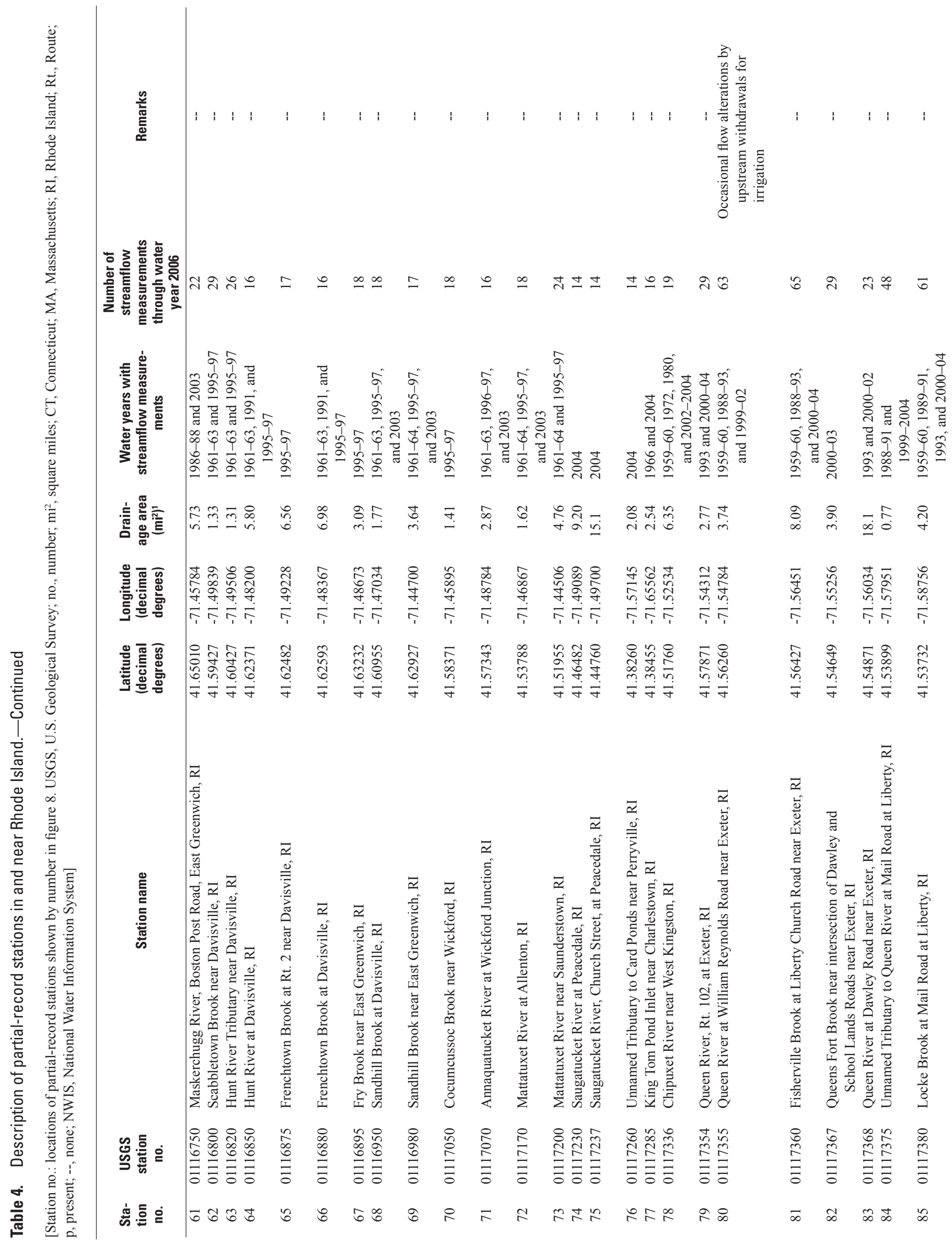




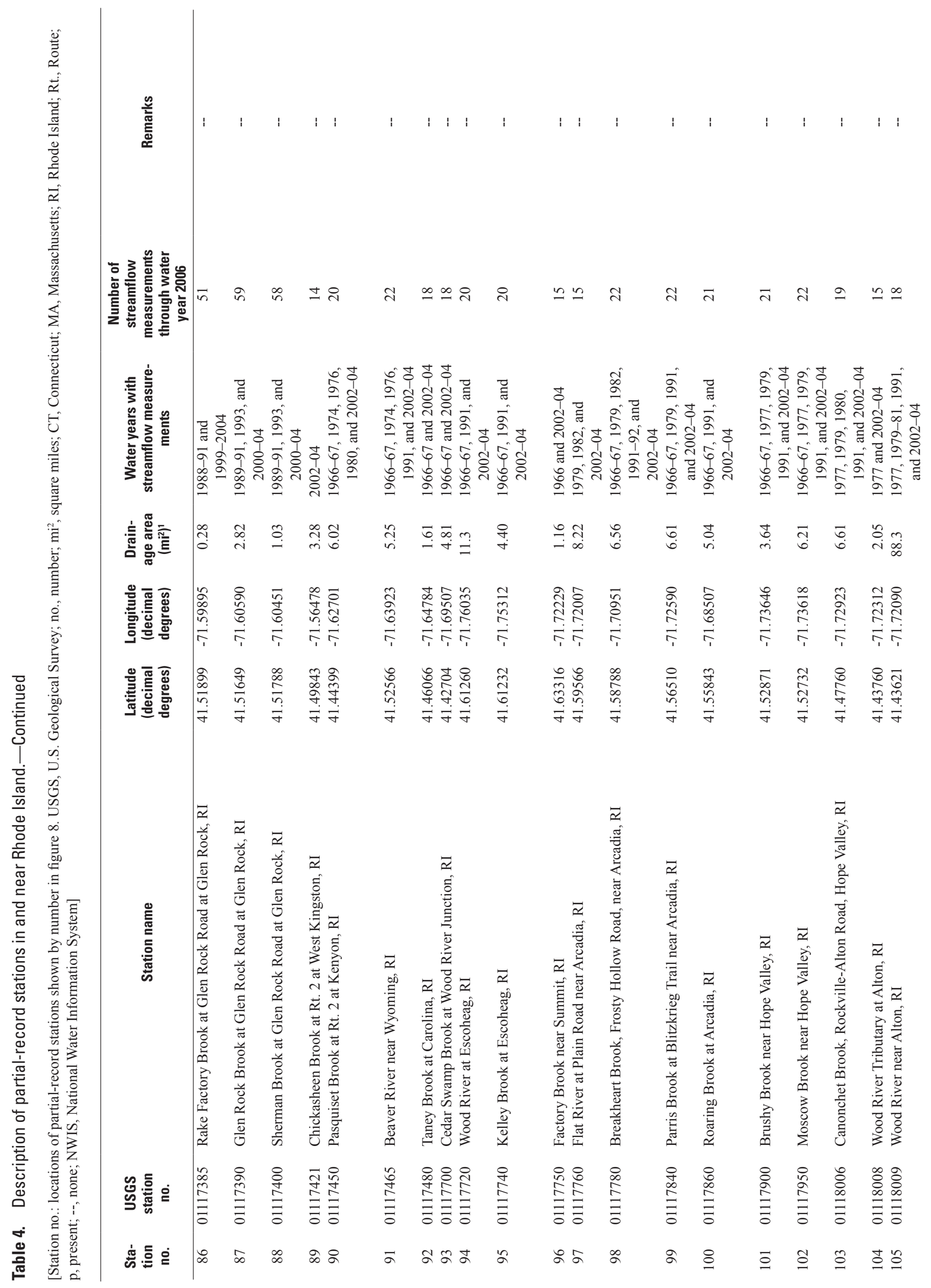




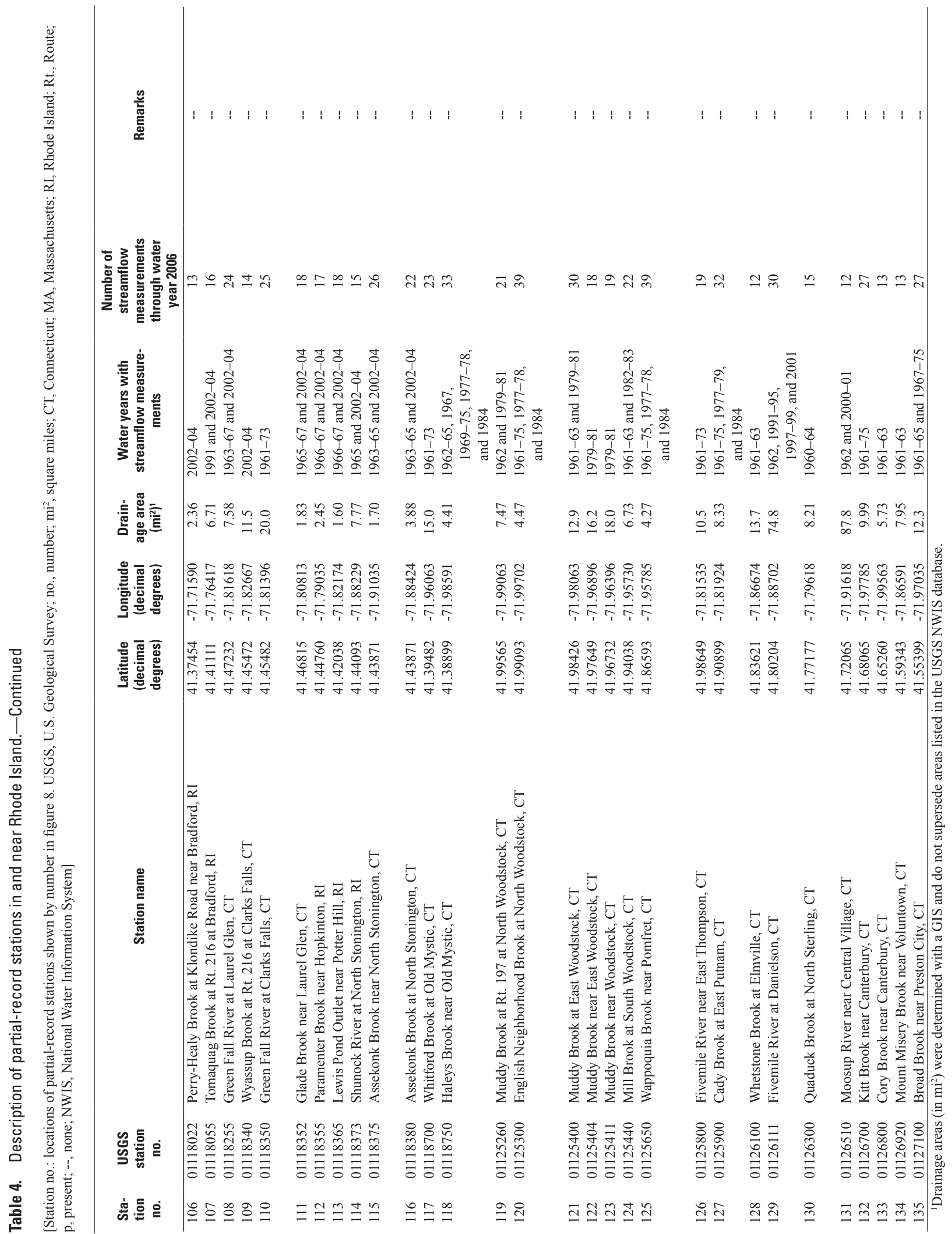




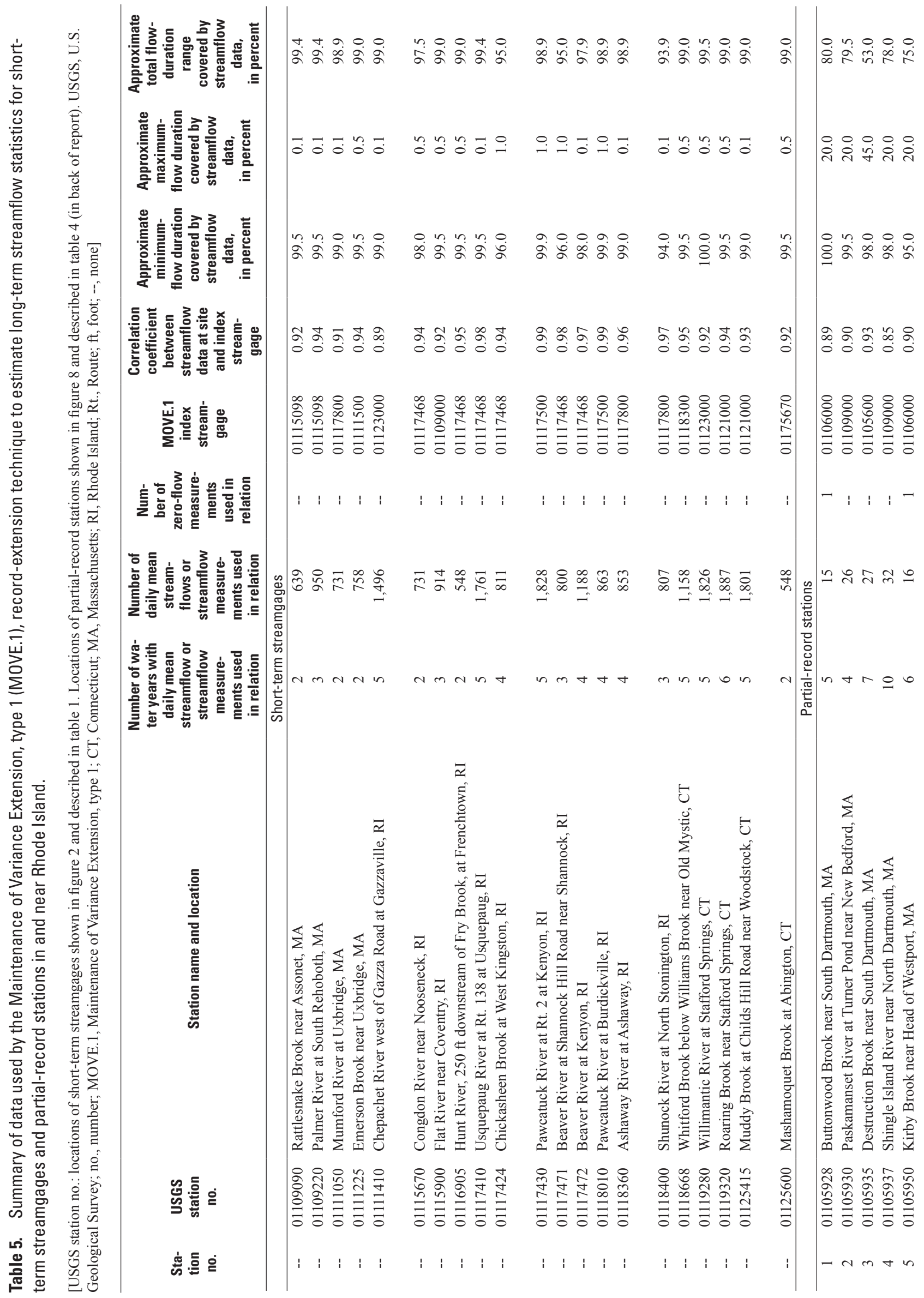




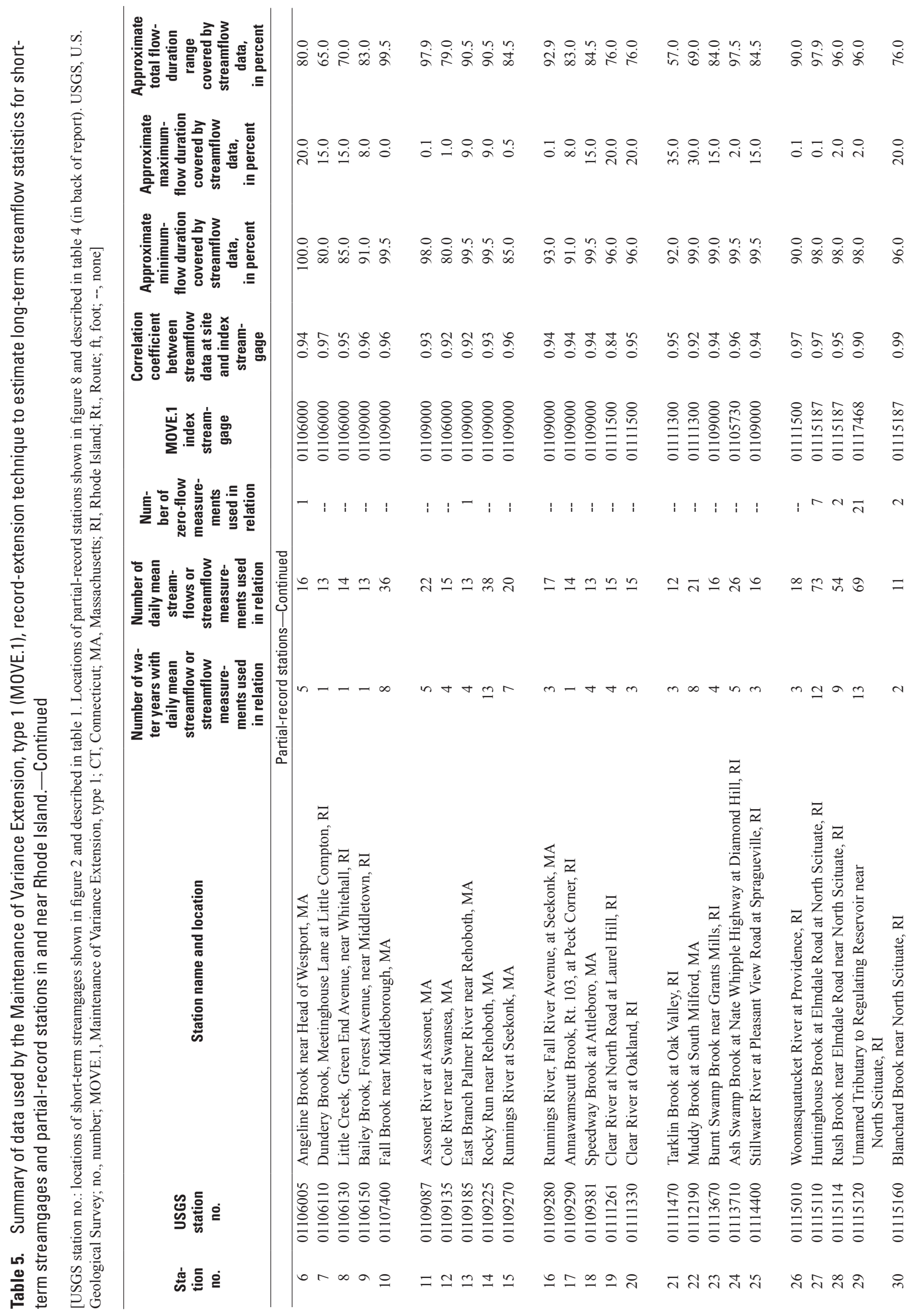




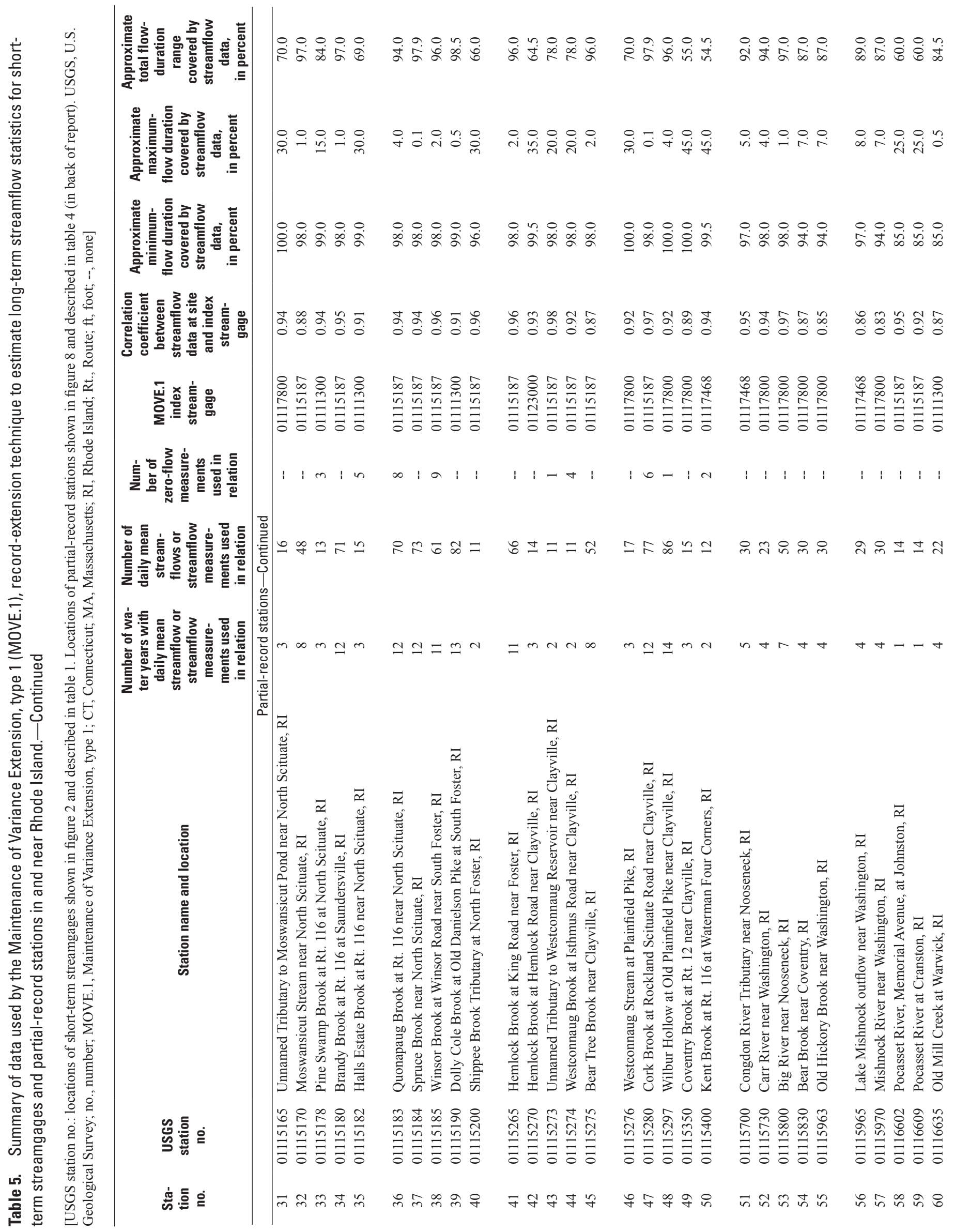




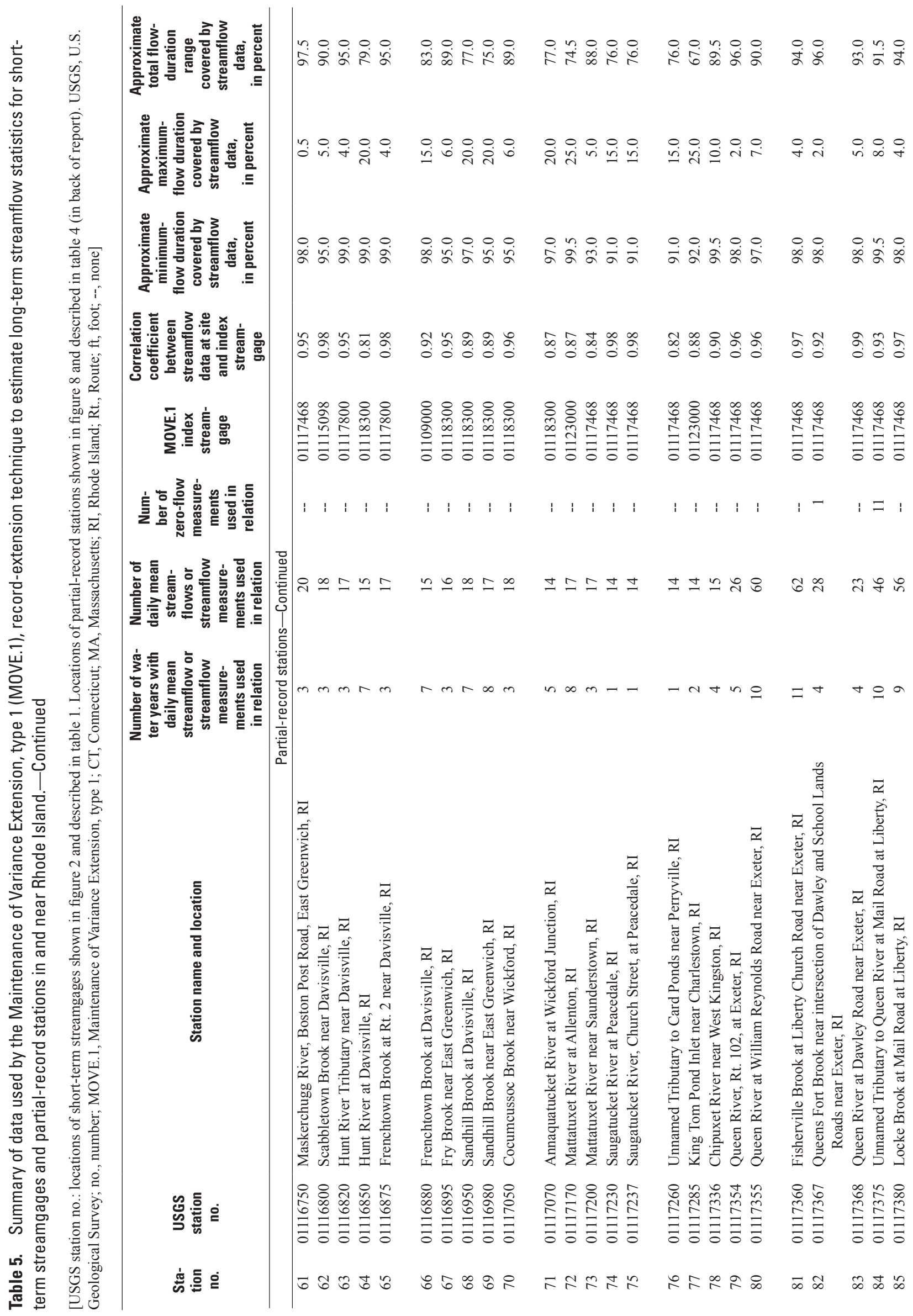




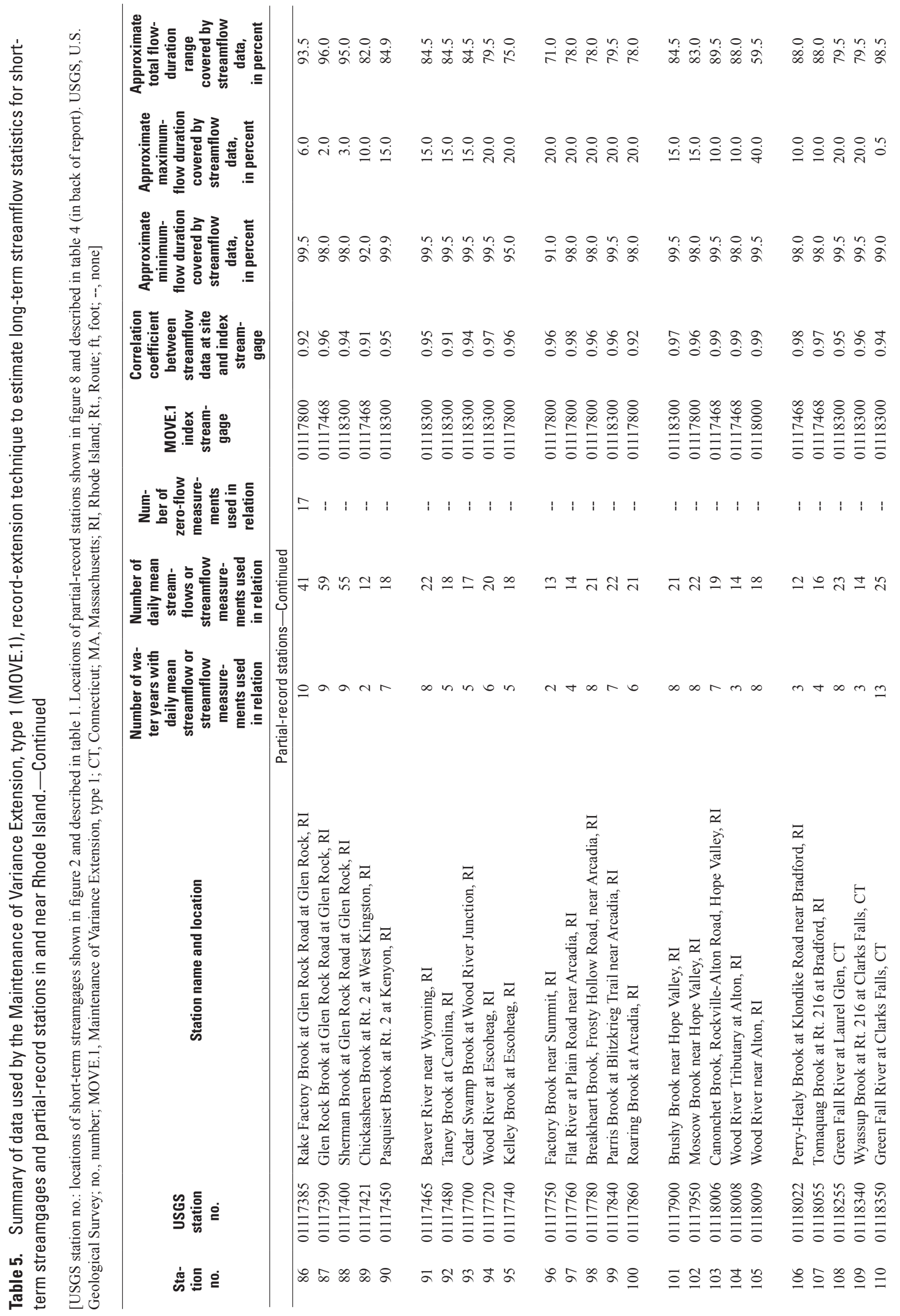




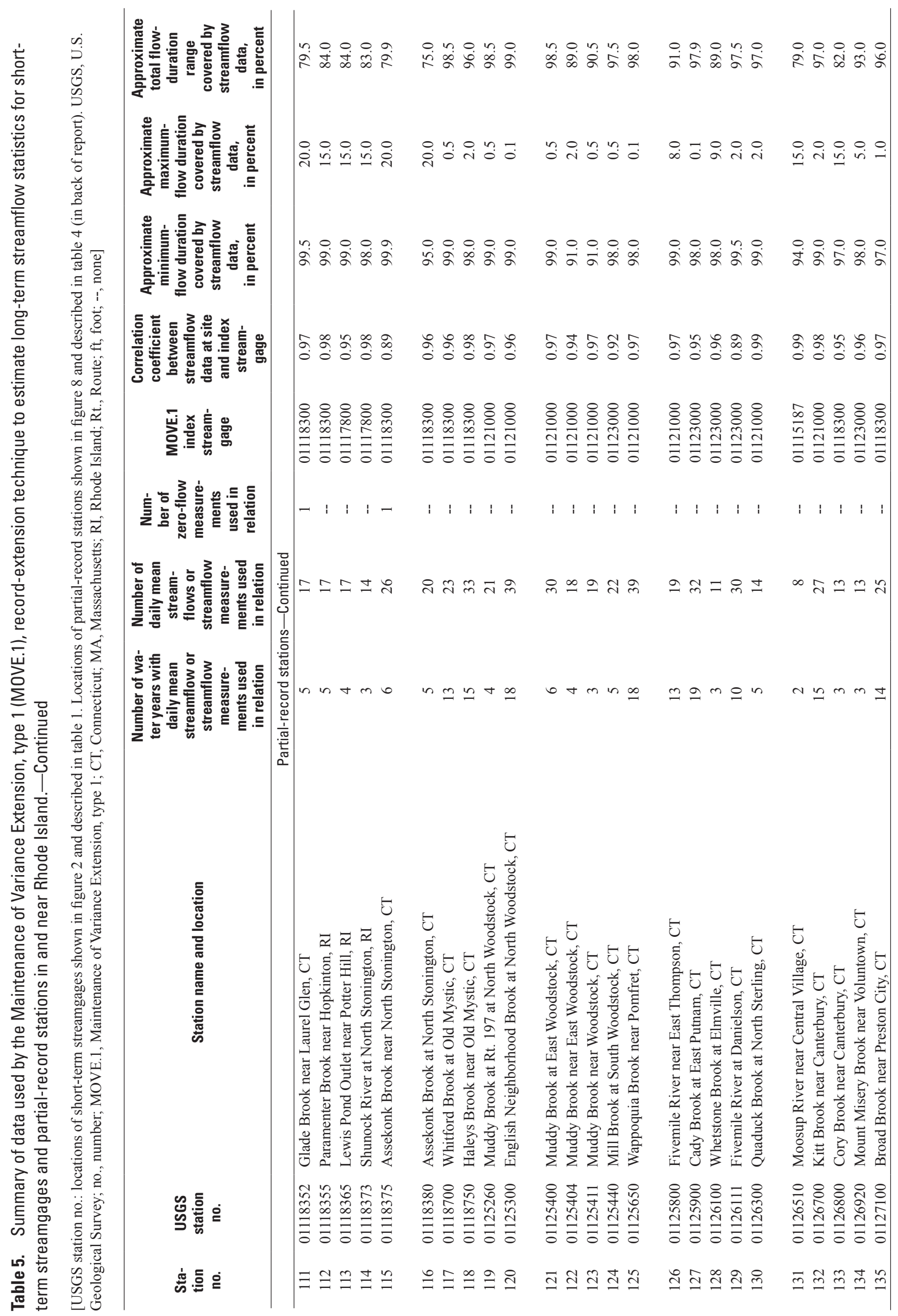



Prepared by the Pembroke Publishing Service Center. For more information concerning this report, contact:

\section{Office Chief}

U.S. Geological Survey New England Water Science Center Massachusetts-Rhode Island Office 10 Bearfoot Road

Northborough, MA 01532

dc_ma@usgs.gov

or visit our Web site at: http://ma.water.usgs.gov 
